U. S. Geological Survey

Water Resources Division
Caribbean District Open - File Report

\title{
A SURVEY OF THE WATER RESOURCES OF ST. THOMAS, VIRGIN ISLANDS
}
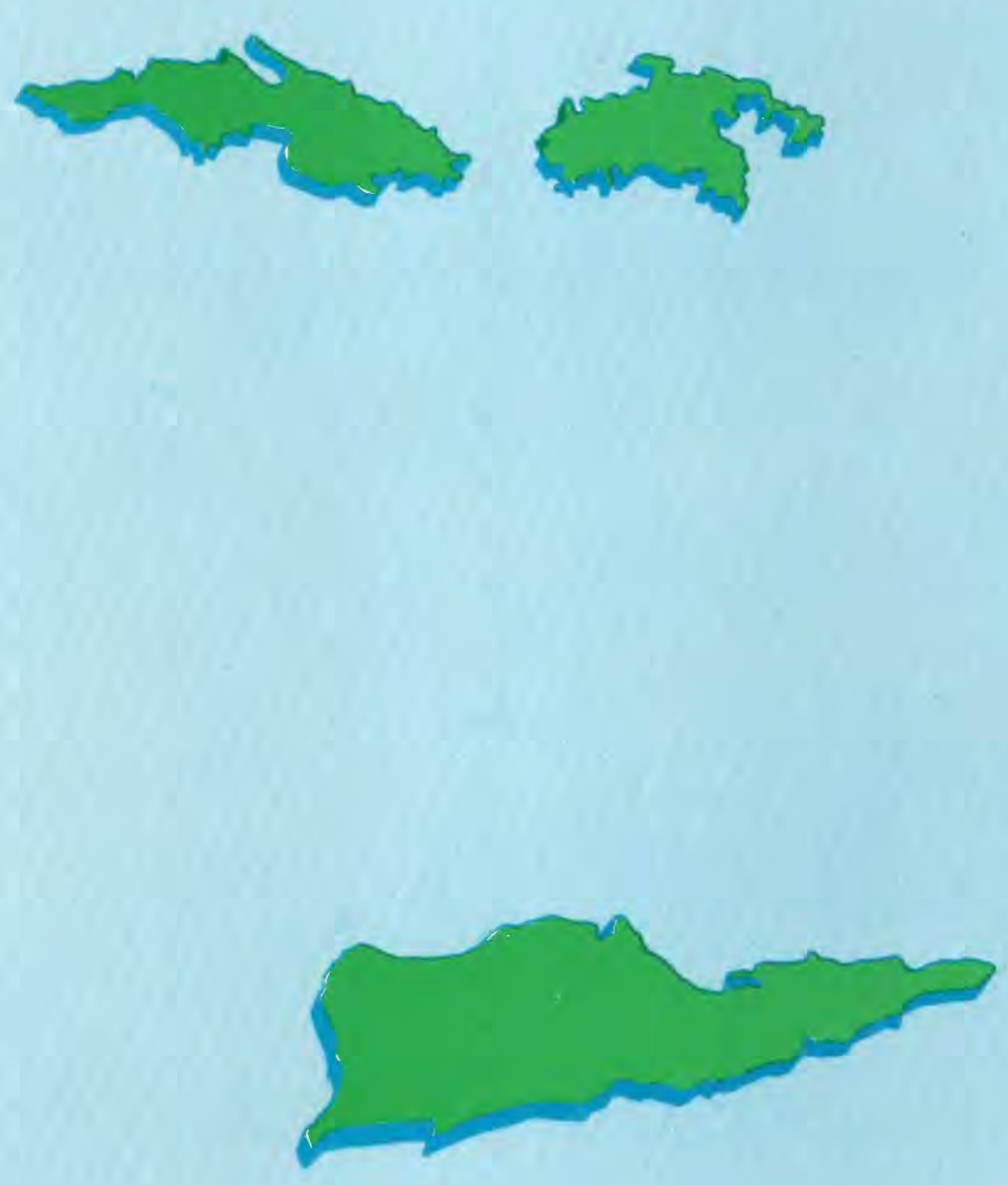

UNITED STATES DEPARTMENT OF THE INTERIOR

IN COOPERATION WITH THE 


\section{ABSTRACT}

St. Thomas, with an area of 32 square miles, is the second largest of the Virgin Islands of the United States. The island is mountainous, and slopes commonly exceed 35 degrees along a central ridge 800 to 1,200 feet high running the length of the island. The general appearance is a panorama of numerous steep interstream spurs and rounded peaks.

The island is made up of rocks of Cretaceous age, mostly volcanic flows and breccias. A thin limestone and tuffaceous wacke complete the sequence of major rock types. All the rocks have been tilted and dip about 50 degrees north.

Water in Charlotte Amalie, the capital, is supplied by sea-water desalting and water barged from Puerto Rico and is augmented by hillside rain catchments and individual roof catchments. Rainwater augmented by water hauling and a few wells is the source of water for the rural areas.

Streamflow is meager--2 to 8 percent of the annual rainfall-and is predominantly storm runoff. Runoff after rainstorms seldom exceeds 5 percent of the rainfall. Runoff is rapid, however, and flash floods occa sionally occur.

Test drilling has shown that water can be obtained from fractured volcanic rocks in nearly all parts of the island. Wells will yield, generally, less than 1,000 gpd (gallons per day). In the upper Turpentine Run Valley and the Lovenlund Valley, shortterm yields of individual wells are as great as 100 gallons per minute. Estimates of potential yield from these areas are 300,000 and $100,000 \mathrm{gpd}$, respectively. Two smaller areas--Long Bay and Lindberg Bay on the outskirts of Charlotte Amalie have estimated ground-water yields of 70,000 and 30,000 gpd, respectively. Fully developed, the surface- and ground-water resources of the island could yield 1.3 million gallons of water per day.

Ground water is slightly saline, commonly containing more than 1,000 milligrams per liter dissolved solids. The principal source of the minerals is bulk fallout of sea- and land-derived dust from the atmosphere. Solution of minerals from the rocks of the aquifers is the second largest contributor. Nitrate and some of the bicarbonate content of the water is probably derived from vegetation and animal and human wastes.

Surface water is similar in mineral content to ground water during base flow. 


\section{UNITED STATES \\ DEPARTMENT OF THE INTERIOR \\ Geological Survey}

A SURVEY OF THE WATER RESOURCES OF

ST . THOMAS, VIRGIN ISLANDS

by

D. G. Jordan and O. J. Cosner

Prepared in cooperation with the

Government of the Virgin Islands

of the United States 
1. The natural water supplies of St. Thomas are insufficient to meet water demands. They do augment public supplies, which mostly are from sea-water desalting and barging of fresh water from Puerto Rico, and can be of great benefit as supplemental water supplies in rural areas.

2. Water supplies of St. Thomas, if fully developed, will yield about 1.3 million gpd (gallons per day) of potable water. About onethird of the potential can be developed in selected areas for public supplies, whereas the remainder can be developed for individual domestic and small commercial uses.

3. Areas in which ground water can be developed for public supply are:

Turpentine Run Valley.--About $300,000 \mathrm{gpd}$ in the upper valley and $50,000 \mathrm{gpd}$ in the lower valley.

Lovenlund Valley.--About 100,000 gpd. The retention of storm runoff and later release to recharge the limestone in the valley could increase the yield by about $40,000 \mathrm{gpd}$.

Charlotte Amalie. --About 70,000 gpd in the vicinity of the racetrack at Long Bay. About $30,000 \mathrm{gpd}$ in the vicinity of Bourne Field north of the airport. Urban development in the se areas will reduce recharge and thus decrease the potential for these areas.

Wells yielding as much as 1,000 gpd can be developed for domestic use in nearly all parts of St. Thomas. Brackish water may be encountered near the sea and on the major peninsulas.

4. In years of normal rainfall, discharge of Turpentine Run is estimated to be 36 million gallons annually $(25$ million gallons from the upper basin and 11 million gallons from the lower basin). The utilization of this discharge, which is predominantly storm runoff, would require the use of present reservoirs and the construction of additional reservoirs.

The utilization of the 25 million gallons annual discharge at Bonne Resolution Gut is essentially limited to the use of "run of the river" flow. There is no place where a reservoir can be built to retain large amounts of runoff.

5. Overall water quality is poor, commonly containing more than 1,000 milligrams per liter dissolved solids. Much of the mineral content of the water is attributed to bulk fallout derived from sea and land sources. Chemically it lies between a sodium chloride water and a sodium calcium bicarbonate water.

6. The water resources of St. Thomas are seriously threatened by pollution from sewage. Numerous residences utilizing septic tanks for sewage are being built in rural areas on lots of one-quarter of an acre to over one acre. The thin soil cover is not capable of filtering these wastes. Sewage either escapes to the surface or enters the open joints and fractures of the bedrock and subsequently the ground-water reservoir.

Primary sewage-disposal plants have been built for a few communities. Effluent from these plants is being discharged to small polishing pond $s$ for about 1 day retention and then discharged to generally dry stream channels. Breakdowns in these plants will result in raw sewage being discharged to the streams.

7. Hillside rain catchments will recover about 70 percent of the rainfall. In a year of average rainfall ( 44 inches) a catchment will yield about 19.3 gallons per square foot of catchment. During 1955-64 the annual yield was 17.4 gallons per square foot. To store and utilize all the rainfall would have required 17 gallons of storage per square foot of catchment. An optimum recovery of 16.3 gallons per square foot could have been realized, however, with only 5.3 gallons of storage per square foot.

8. Flash floods resulting from high-intensity rainfall can hardly be avoided. In Charlotte Amalie the natural drainageways have been encroached upon, canalized, and in some places obliterated. The carrying capacity of the stream channels is further reduced by trash and the consequent reduction of effective cross-sectional area of the channels at their outlets to the sea.

The natural channel of Turpentine Run in eastern St. Thomas has been encroached upon by roads, land fill, and buildings on the flood plain. In places, the channel can no longer carry the flood flows it was once capable of. The result is more extensive inundation of the flood plain with subsequently greater damage to the buildings there. 


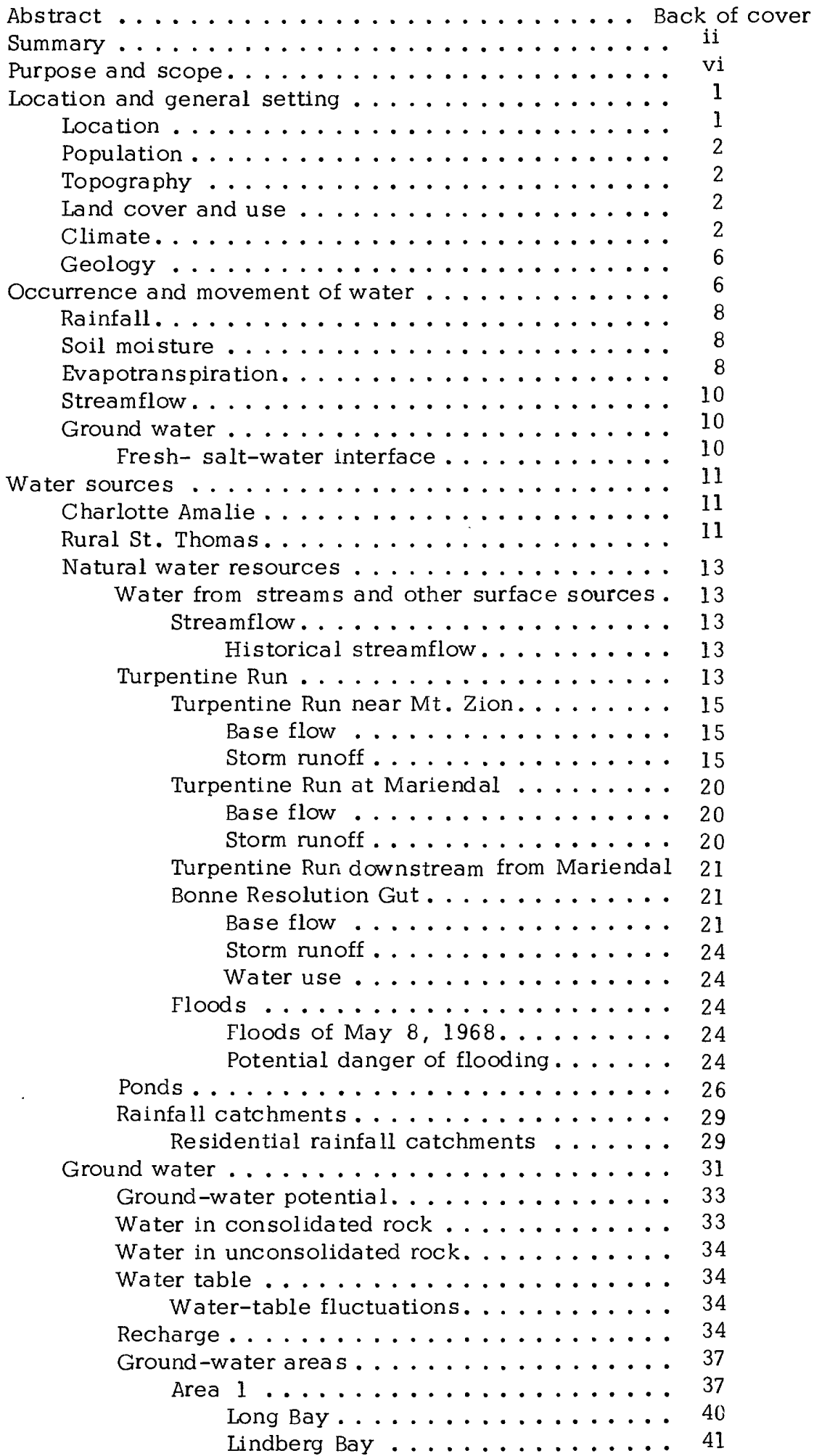


Water sources--continued

Ground water--continued

Ground-water areas--continued

Area $2 \ldots \ldots \ldots . \ldots . . \ldots . . . \ldots 41$

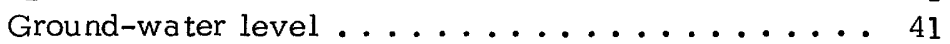

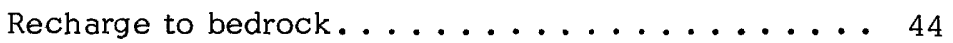

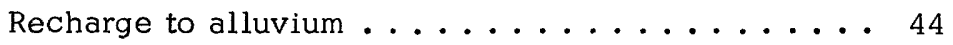

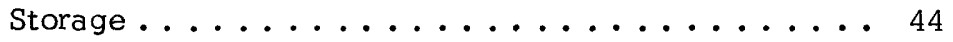

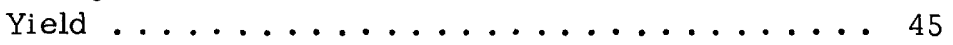

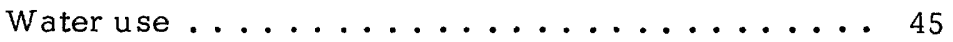

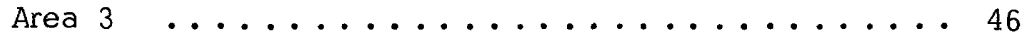

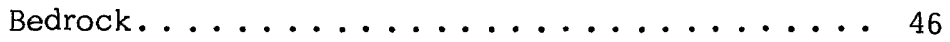

Alluvial and beach deposits............ 46

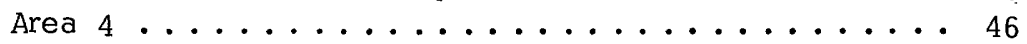

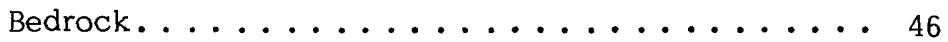

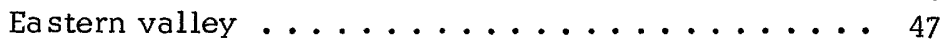

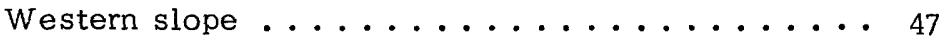

Area $5 \ldots \ldots \ldots \ldots \ldots \ldots \ldots . \ldots \ldots$

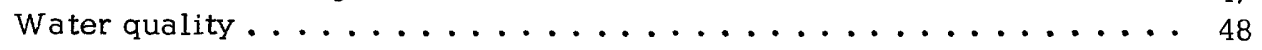

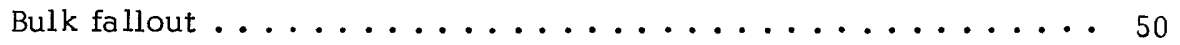

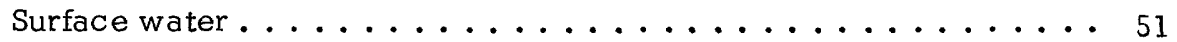

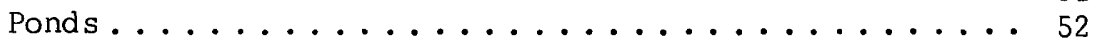

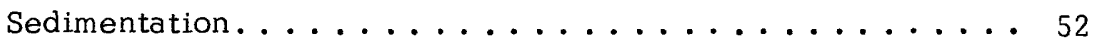

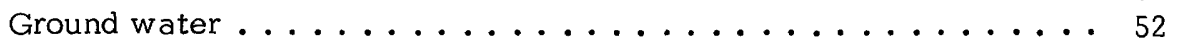

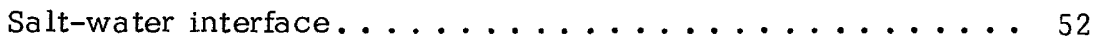

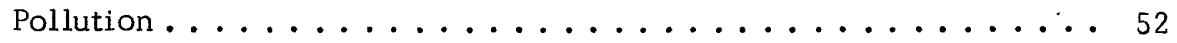

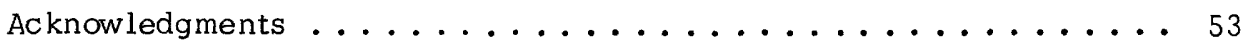

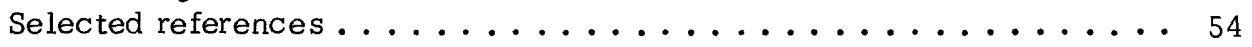

\section{L L US TRATION S}

Page

Figure 1. Map of the location of the Virgin Islands of the United States 1

2. Wind rose of annual percentage frequencies of wind

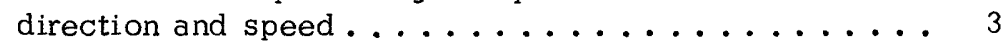

3. Map of geology of St. Thomas .............. . . . . . . . . . . .

4. Graph of monthly average rainfali at Charlotte Amalie . . . . 7

5. Duration curve of annual rainfall at Charlotte Amalie,

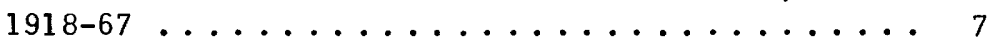

6. Graph of accumulated departure from average, 10-year running average, and annual rainfall at Charlotte Amalie 7

7. Isohyetals, in inches, of distribution of long-term rainfall and individual rainstorms, St. Thomas......... 9

8. Graph of potable water sources for Charlotte Amalie . . . . 12

9. Graph of daily discharge, Turpentine Run near

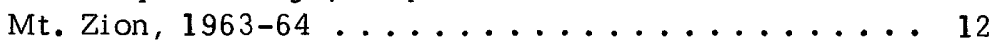

10. Graph of daily discharge, Turpentine Run at

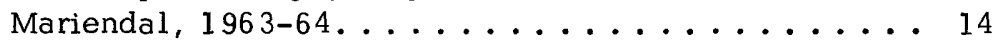


Figure 11. Graph of daily discharge, Bonne Resolution Gut at Bonne Resolution, 1963-64 ... 14

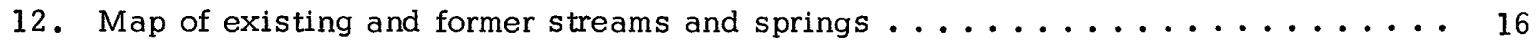

13. Graph of monthly discharge at Turpentine Run near Mt. Zion . . . . . . . . . 16

14. Graph of relation of rainfall to discharge, Turpentine Run near Mt. Zion . . . . . 17

15. Flow-duration curves at Turpentine Run near Mt. Zion . . . . . . . . . 18

16. Graph of rainfall-storm runoff at Turpentine Run near Mt. Zion. . . . . . . . . . 19

17. Graph of monthly discharge at Bonne Resolution Gut and monthly rainfall

at Dorothea Agriculture Station. . . . . . . . . . . . . . . 20

18. Graph of relation of monthly rainfall and discharge and annual rainfall and discharge at Bonne Resolution Gut . . . . . . . . . . . . . 22

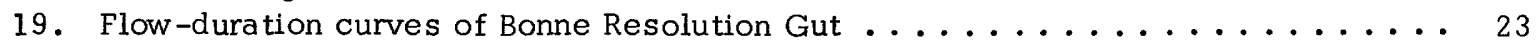

20. Graph of rainfall-storm runoff at Bonne Resolution Gut . . . . . . . . . . . 25

21. Graph of rainfall-peak stage relation at Turpentine Run near Mt. Zion . . . . . . 26

22. Graphs of stage and chloride content of water of pond, Estate Hoffman . . . . . 27

23. Graphs of water loss from pond, rainfall, and pan evaporation, Estate Hoffman. . . 28

24. Mass curve of 70 percent of monthly rainfall in gallons per square foot

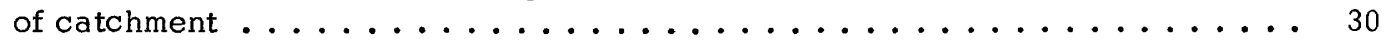

25. Graph of annual cost of water from a roof catchment ............. 31

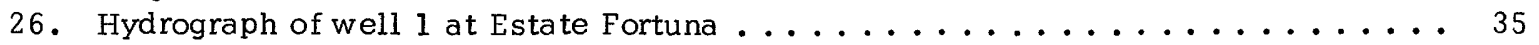

27. Hydrograph of well 24 at Estate Mariendal. . . . . . . . . . . . . . . 35

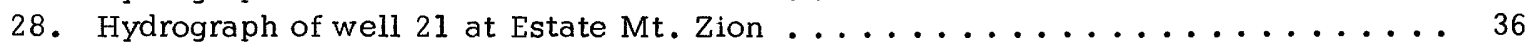

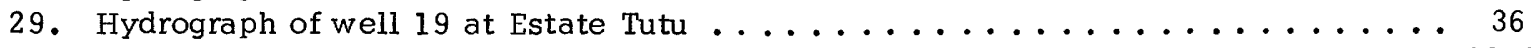

30. Map of ground-water areas of St. Thomas . . . . . . . . . . . . 38-39

31. Map of contours of water table in Turpentine Run basin, August 1955 . . . . . 42

32. Map of contours of water table in Turpentine Run basin, January $1966 \ldots$. . . . . 43

33. Graph of frequency of 48-hour rainstorms and recharge to bedrock aquifer at

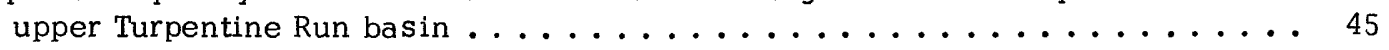

34. Graph of chemical classification of water . . . . . . . . . . . . . . 50

35. Graph of relation of chloride content of water to discharge at Turpentine Run and Bonne Resolution Gut . . . . . . . . . . . . . . . .

\section{TAB LES}

Table 1. Mean monthly air temperature, Charlotte Amalie 1922-60; average wind velocity and relative humidity, Harry S. Truman Airport 1953-58 ....... 3

2. Annual discharge, Turpentine Run near Mt. Zion. Rainfall at Estate Fort Mylner . 15

3. Annual discharge, Bonne Resolution Gut at Bonne Resolution. Rainfall at Dorothea Agriculture Station . . . . . . . . . . . . . . .

4. Scale of values for determining ground-water potential from physical criteria and examples for selected wells . . . . . . . . . . . 32

5. Estimated yield of ground-water areas . . . . . . . . . . . . . . . 37

6. Estimated annual recharge to bedrock aquifer of upper Turpentine Run basin . . . . 44

7. Ground-water pumpage and use in Area 1 , in million gallons . . . . . . . . . 46

8. Analyses of water of St. Thomas . . . . . . . . . . . . . . . . 49

9. Comparison of bulk fallout and dilute sea water ............... 50 
In 1962, the Government of the Virgin Islands with the encouragement of the Office of Territories, U.S. Department of Interior, requested that the U.S. Geological Survey begin a long range study of the water resources of the Virgin Islands of the United States. Rapid population growth, a rising standard of living, developing tourism, and industry were making increasing demands on the water supply.

It was recognized that in time the islands, particularly St. Thomas, would have to rely on the desalting of sea water for much of their water needs. In fact, a small 250,000 gallons per day plant was put into operation in 1962. But it was recognized also that full use would have to be made of all water sources of the islands. The purpose of the study, therefore, was to determine where and how much water was available, not only fresh surface-water and ground-water supplies, but also rainfall and brackish water.

The U.S. National Park Service anticipated a major surge in day visitors and overnight campers once roads and trails were improved in the newly established St. John National Park and so requested a companion study by the Survey. Water was needed for Park Service personnel and visitors at recreation areas and camp sites. Although the anticipated water demand was not large, it was vital to the operation of the Park.

Because each of the islands, St. Thomas, St. John, and St. Croix, is a complete hydrologic unit, each island will be reported on separately. 


\section{A SURVEY OF THE WATER RESOURCES OF}

\section{ST. THOMAS, VIRGIN ISLANDS}

by D. G. Jordan and O. J. Cosner

\section{LOCATION AND GENERAL SETTING}

\section{Location}

The Virgin Islands, forming part of the Antilles Island Arch separating the Caribbean Sea from the Atlantic Ocean, are about 1,400 miles southeast of New York and almost 1,000 miles east southeast of Miam1. St. Thomas, the northwesternmost island, lies about 50 miles east of Puerto Rico (fig. 1).

St. Thomas is the second largest of the more than 50 islands and cays constituting the Virgin Islands of the United States. The island is approximately 14 miles long and 2 to 3 miles wide and has an area of 32 square miles. Lying within a few miles of the coast are nearly 40 smaller islands, ranging in area from slightly less than a square mile to a few hundred square feet.

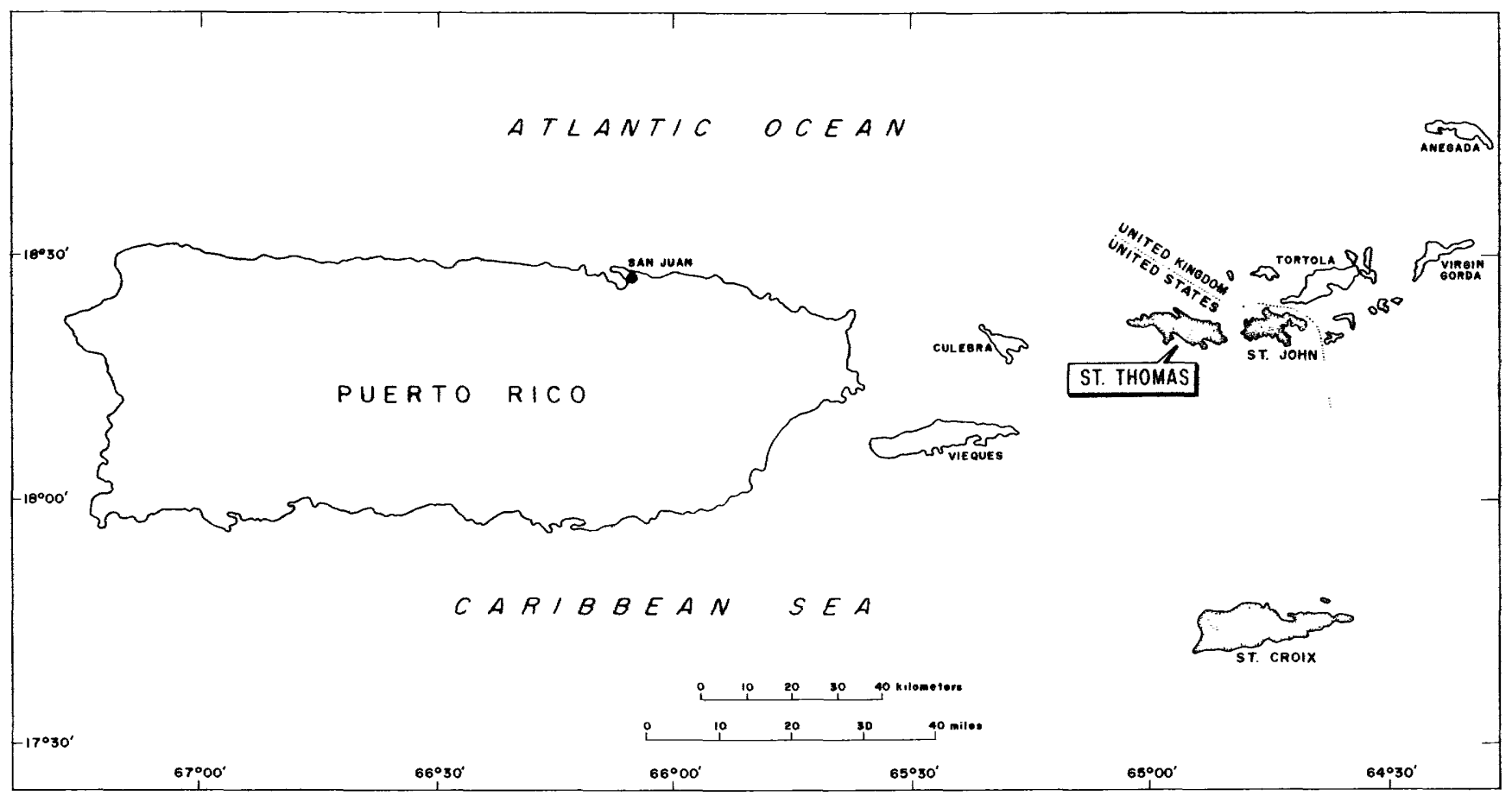

Figure 1.--Location of the Virgin Islands of the United States. 


\section{Population}

St. Thomas has about 17,000 permanent residents and a transient population of tourist and imported laborers of about 8,000 . The majority of the population is urban--about 20,000 people live in Charlotte Amalie, the only city and also the seat of government of the Virgin Islands. The permanent population is increasing rapidly and is expected to double by 1980 (unpublished data, V.I. Planning Board, 1964).

\section{Topography}

The land surface is almost entirely sloping and extends seaward from a central ridge, 800 to 1,200 feet high, running the length of the island. The slopes, which commonly exceed 35 degrees, are dissected by numerous stream courses of steep gradient. The general appearance is a panorama of steep interstream spurs and rounded peaks. Flat land is confined to the Charlotte Amalie area and a few small alluvial-filled embayments. The only variation in the general topography is in the upper valley of Turpentine Run in eastern St. Thomas. The valley has relatively gentle topography consisting of rolling hills in a basin surrounded by steep slopes and sharp ridges .

\section{Land Cover and Use}

At one time almost all the land, including that characterized by steep slopes, was under cultivation, primarily for grazing or growing sugarcane or cotton. Agriculture, however, has declined almost to extinction. A few square miles of land are still devoted to grazing in the eastern part of the island, and about 10 acres are used for truck gardening in the north central part. The remainder has been allowed to revert to brush and secondary forest.

Now, land use is changing rapidly, much of it brought on by the jet age and its rapid mass transportation. Increasing population, in part caused by development of the island as a retirement haven and by tourism, results in more land being used for urban and suburban development. The increase in population not only makes new demands upon the water supply, but also the changes in land use could very well affect the available quantity and quality of the water resources.

\section{Climate}

The average annual rainfall is about 45 inches and the average temperature is only $80^{\circ} \mathrm{F}$, but the prevailing impression of the climate is one of dryness, especially in the winter. This is especially true of the east end of the island, where, because of orographic effects, rainfall is only about 80 percent of that elsewhere.

Rain is seasonal, nearly half falling between August and November. February and March are the driest months and September and October the wettest. Most of the rain occurs as short, intense showers lasting but a few minutes. Rains exceeding 1 inch, with accompanying overcast, cloudy skies, come but six or seven times a year. Thus, there are few days when the sun does not shine.

Although major rains are rare, their volume is notew orthy. The greatest rainfall of record was 18.0 inches September 13-14, 1928, during a hurricane. The last great rain in recent years was 10.6 inches May 8,1960 , the result of a stationary tropical depression.

The island lies in the path of hurricanes and occasionally receives heavy rains and high winds from passing storms. The incidence of direct hits is low--damaging storms having a frequency of about one every 33 years. The last hurricane to cause extensive damage was in September 1928.

The direct rays of the sun are very hot, but air temperature is modified by the almost constant trade wind. Air temperature (table 1) ranges from a mean low of $72.0^{\circ} \mathrm{F}$ in February to a mean high of $87.8^{\circ} \mathrm{F}$ in August. The highest daily temperature of record was $95^{\circ} \mathrm{F}$ and the low, $63^{\circ} \mathrm{F}$.

The prevailing wind direction is from the east. Northeast and southeast winds are relatively common, but west winds are rare. Monthly average wind velocity during 1953-58 at Harry S. Truman Airport is given in table 1. A wind rose for the same period is shown in figure 2 .

Relative humidity is high owing to the proximity of the sea. At Harry S. Truman Airport during 1953-58 relative humidity was highest, averaging 81 percent, in the early morning hours, and lowest, averaging 66 percent, in the early afternoon. Average daily humidity is given in table 1 . 
Table 1.--Mean monthly air temperature, Charlotte Amalie 1922-60; average wind velocity and relative humidity, Harry S. Truman Airport 1953-58. Data from National Weather Service

\begin{tabular}{|l|l|l|l|l|l|l|l|l|l|l|l|l|}
\hline Jan. & Feb. & Mar. & Apr. & May & June & July & Aug. & Sept. & Oct. & Nov. & Dec. & Average \\
\hline
\end{tabular} Air temperature, ${ }^{\circ} \mathrm{F}$

\begin{tabular}{l|l|l|l|l|l|l|l|l|l|l|l|l|l|} 
Mean high & 81.9 & 81.6 & 82.4 & 85.8 & 84.8 & 86.3 & 87.2 & 87.8 & 87.6 & 87.0 & 85.5 & 83.4 & 85.1 \\
Average & 77.1 & 76.8 & 77.6 & 78.9 & 80.3 & 81.8 & 82.5 & 82.9 & 82.6 & 81.9 & 80.5 & 78.7 & 80.1 \\
Mean low & 72.3 & 72.0 & 72.9 & 74.3 & 75.8 & 77.3 & 77.7 & 78.1 & 77.5 & 76.8 & 75.5 & 74.0 & 75.4
\end{tabular}
Wind velocity, $\mathrm{mph}$
Average
daily

$$
9.1|9.7|
$$
$9.2|9.0|$
8.8
$9.5|11.1|$
$9.7|7.5|$
6.3
8.0
$9.6 \mid 9.0$
Relative humidity, percent

\begin{tabular}{l|l|l|l|l|l|l|l|l|l|l|l|l|l}
$\begin{array}{c}\text { Average } \\
\text { daily }\end{array}$ & 73 & 72 & 72 & 72 & 74 & 74 & 73 & 76 & 77 & 78 & 76 & 76 & 74 \\
\hline
\end{tabular}

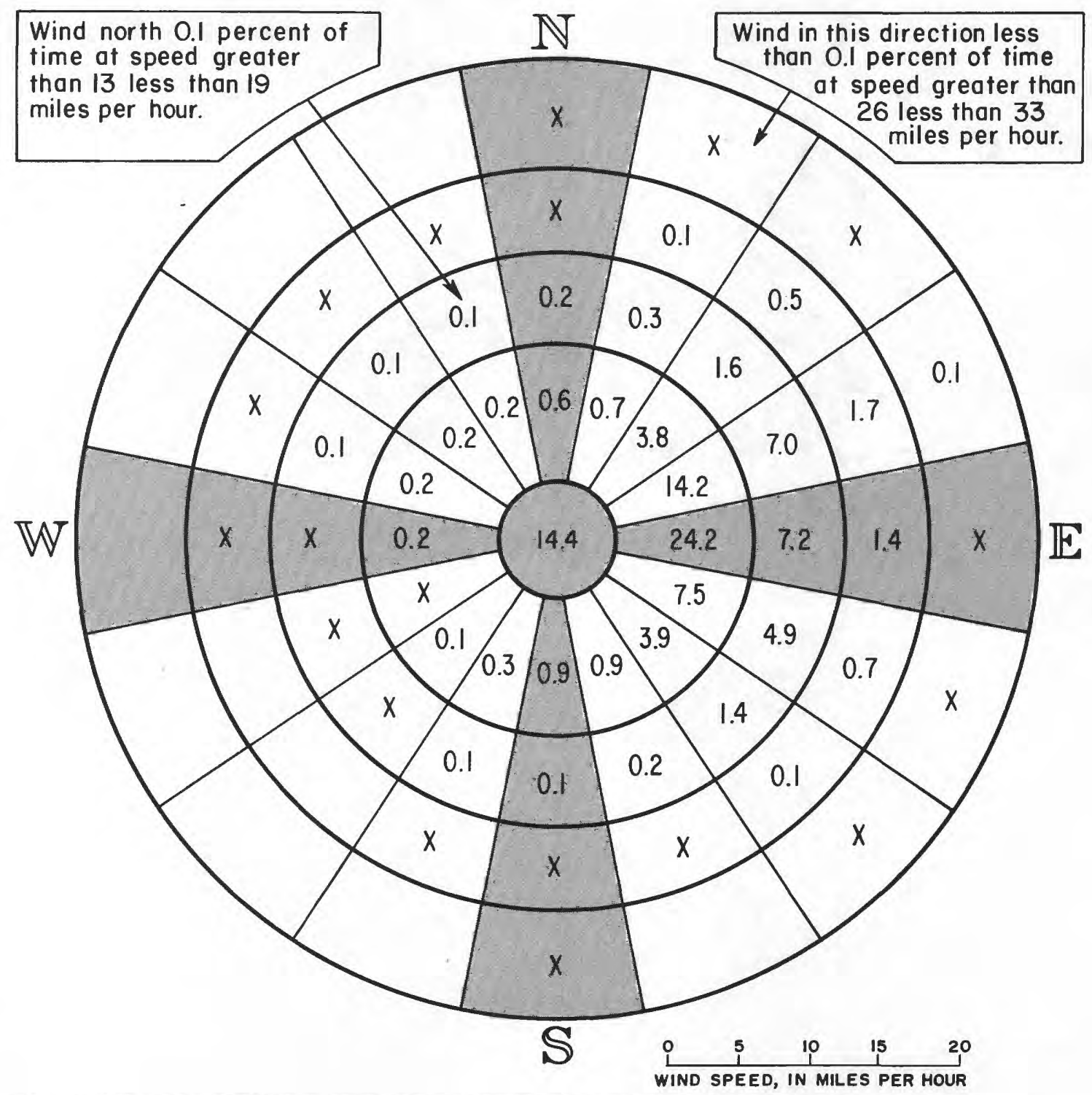

Figure 2.--Wind rose of annual percentage frequencies of wind direction and speed of Harry S. Truman airport, St. Thomas, 1953-58. National Weather Service from Bellante and Garfield (1961). 


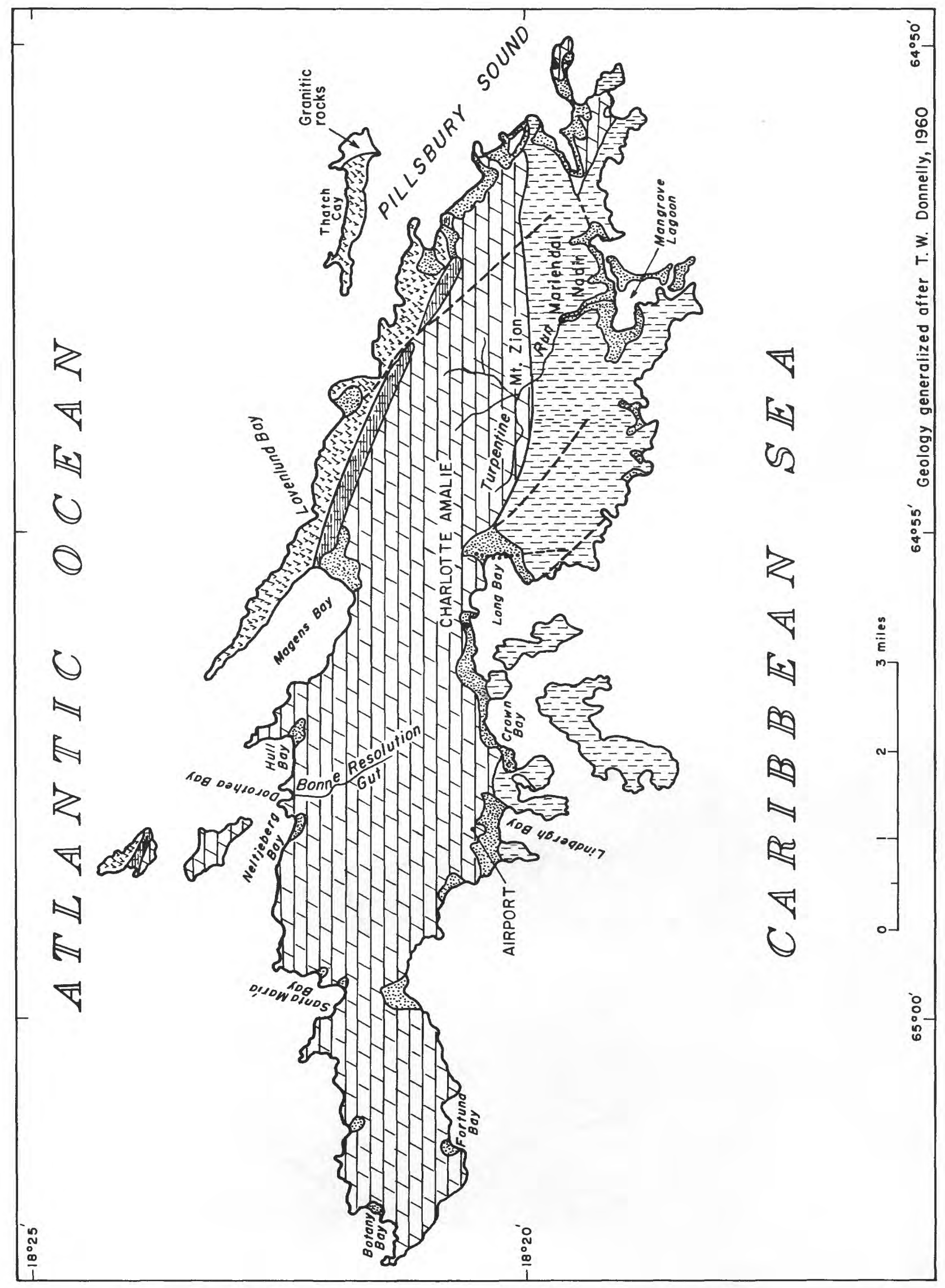




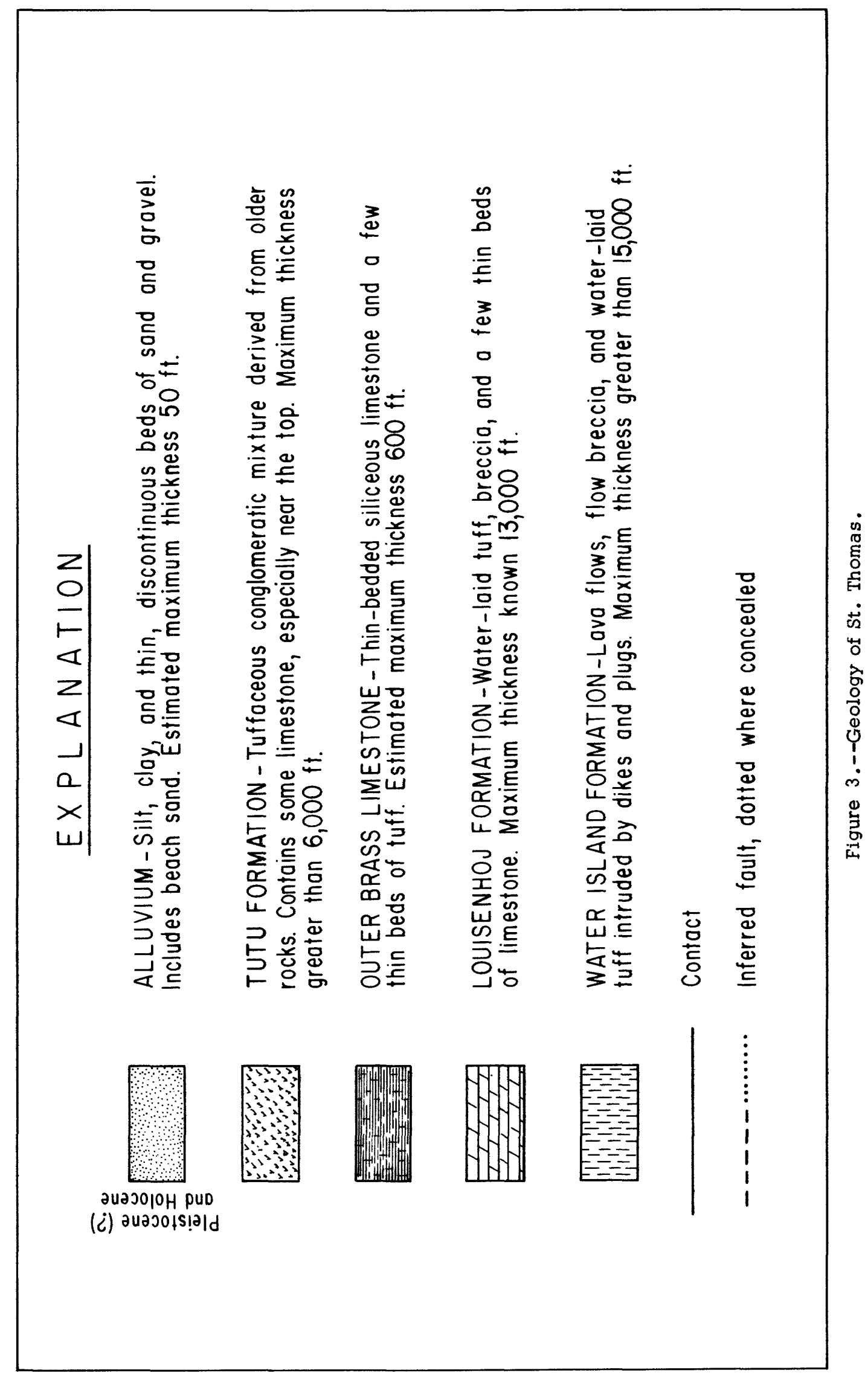




\section{Geology}

The general geology of St. Thomas (fig. 3 ) has been studied for many years, but only recently have the geologic formations been named and described in detail (Donnelly, 1960, 1966). The names of geologic formations used in this report are after Donnelly. The names have not been adopted by the U.S. Geological Survey.

The volcanic and sedimentary rocks of St. Thomas are of Cretaceous (and older?) age. The oldest rocks, those of the Water Island Formation of Donnelly (1960) are predominantly lava flows and flow breccias deposited at great depth on the sea floor. Uplift and subareal erosion followed deposition.

The Louisenhof Formation overlying the Water Island Formation was extruded from a volcanic center probably sited in what is now Pillsbury Sound between St. Thomas and St. John. Near the presumed location of the volcanic orifice the rocks are mostly very coarse reworked cone debris. Farther from the orifice, coarse material lessens and tuffs predominate. Near the base of the Louisenhof Formation is a conglomerate composed chiefly of rock from the Water Island Formation.

The Outer Brass Limestone was deposited on the flanks of the Louisenhoj volcanic cone during a period of volcanic quiescence. It consists of 200 to 600 feet of thin-bedded graphitic silicified radiolarian limestone and a small amount of included tuffaceous material.

The Tutu Formation, the youngest rock exposed on St. Thomas proper, is composed almost entirely of angular debris derived from the Loui senhoj Formation and minor limestone debris from thin limestone deposited contemporaneously with the Tutu Formation.

The rocks were subsequently tilted to form a northward-dipping homocline. Dips range from 15 to 90 degrees and average about 50 degrees. Locally the formations are overturned.

The permeable zones that the se rocks once may have had after deposition have been destroyed by metamorphism or by deposition of minerals in pore spaces. Ground-water movement is now limited to openings along joints and fault zones. The homoclinal structure is cut by sets of faults trending $\mathrm{N} 45^{\circ} \mathrm{W}, \mathrm{N} 55^{\circ} \mathrm{E}$ and north. Three welldefined joint sets parallel each of the major fault directions. The valleys of the island have similar trends and are apparently the result of selective erosion of rock weakened by faulting and jolnting. Prime zones of ground-water availability, therefore, follow the valleys.

Small alluvial deposits ranging from Pleistocene (?) to Holocene in age lie in the valley of Turpentine Run in east-central St. Thomas and the larger coastal embayments.

The alluvium of Turpentine Run lies in a narrow band seldom more than 200 feet in width along the stream. Maximum thickness of the alluvium is about 40 feet. Most of this alluvium, which is composed of silt, fine sand, and clay and contains discontinuous beds of sand and gravel 2 to 3 feet thick, lies in the Mt. Zion-Tutu area of the upper basin and in the narrow valley from Mariendal to Mangrove Lagoon in the lower basin. The alluvium extends out under the lagoon near the mouth of Turpentine Run. Although composed predominately of fine-grained material, the alluvium readily infiltrates streamflow when the groundwater level is below the base of the stream. As such, the alluvium forms a readily rechargeable aquifer, although it is of small extent and yield.

Some coastal embayments headed by intermittant streams contain small deposits of alluvium similar to that of Turpentine Run. Maximum thickness of these deposits is estimated to be 50 feet, and their areal extent seldom is greater than a few acres (an exception being the Long Bay and Airport areas near Charlotte Amalie). Near the sea, the alluvium interfingers with calcareous sand and at times contains lenses of mangroveswamp deposits. Therefore, the deposits are of minor significance as sources of water.

\section{OCCURRENCE AND MOVEMENT OF WATER}

Water moves through a cyclic pattern--the hydrologic cycle--in which there are three storage areas : the sea, the land, and the atmosphere. On the land, surface water and ground water depend on: (1) the amount, intensity, and areal extent of the rainstorms; (2) the slope of the land; (3) the moisture content of the soil and vegetal cover; (4) the infiltration capacity of the soil and underlying rocks; and (5) the size, 


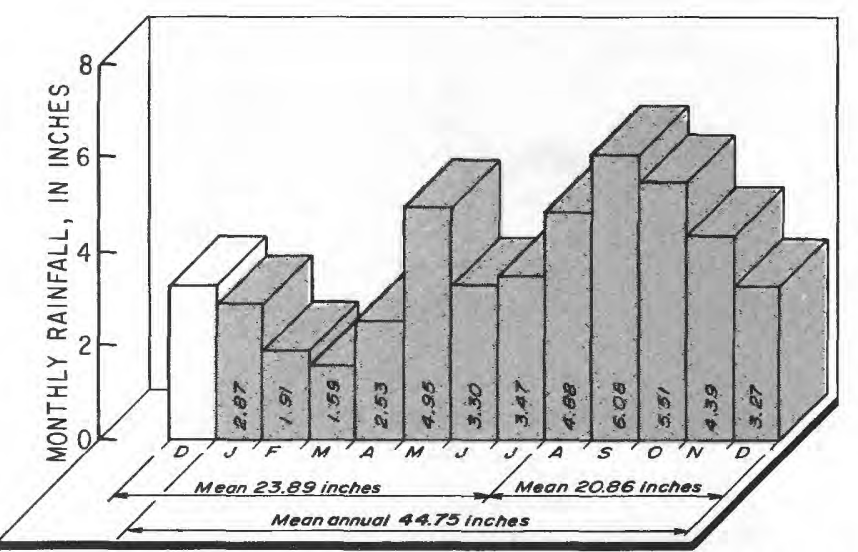

Figure 4.--Monthly average rainfall at Charlotte Amalie, 1918-67. (Based on records of National Weather Service.)

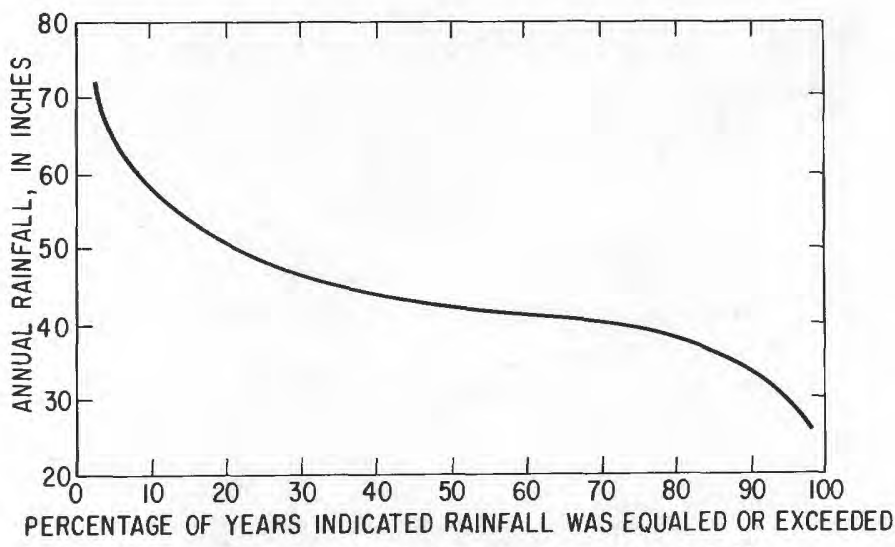

Figure 5.--Duration curve of annual rainfall at Charlotte Amalie, 1918-67. (Based on records of National Weather Service.)

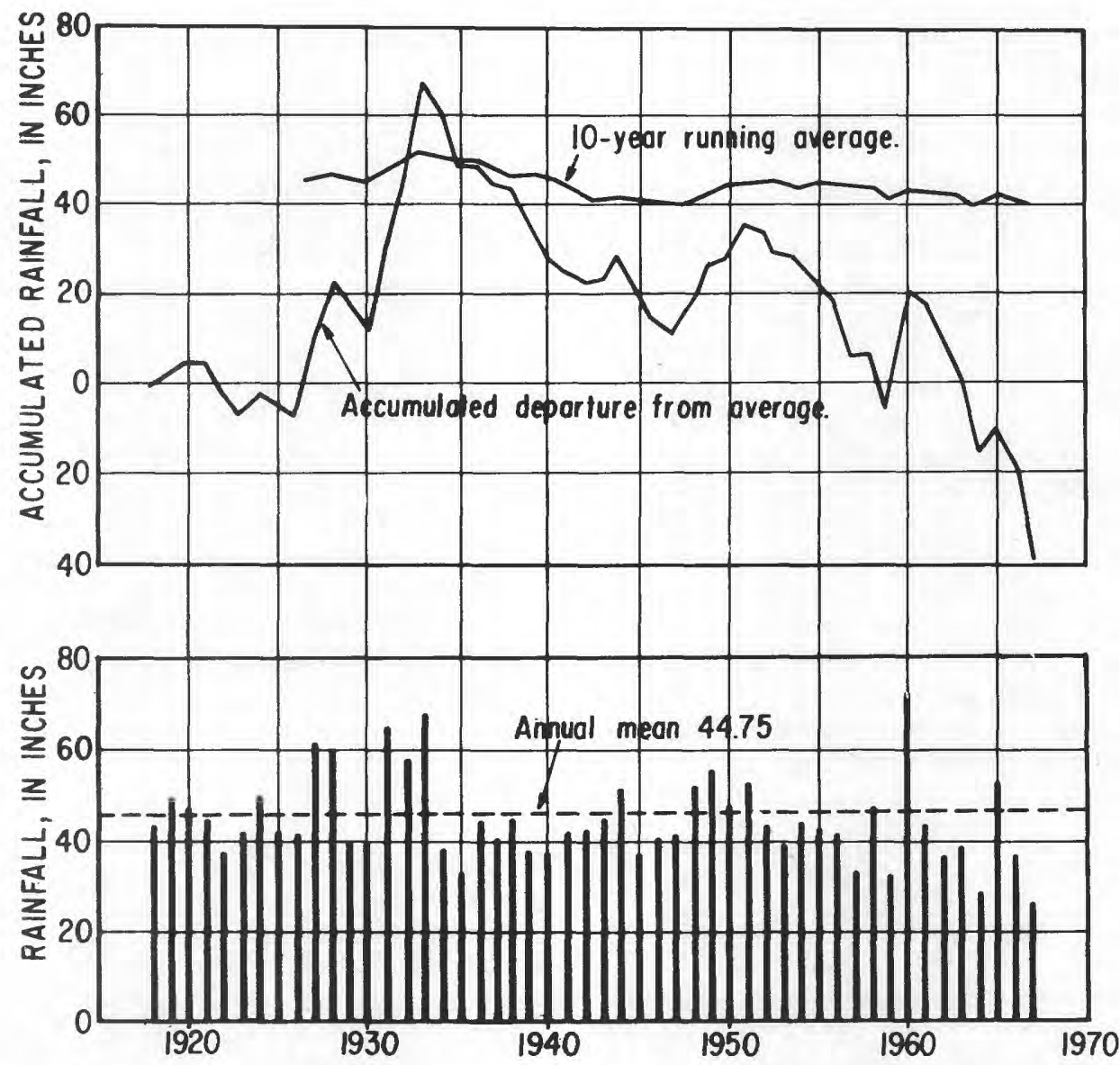

Figure 6.--Accumulated departure from average, tenyear running average, and annual rainfall at Charlotte Amalie. 
number, and interconnection of openings in the aquifer.

\section{Rainfall}

Rain is the only natural source of fresh water to replenish the water resources of the island.

Rainfall is seasonal, with the rainy season in late summer and early fall and a secondary wet season usually in May. Nearly half the rain falls during August-November (fig. 4). Rains exceeding 1 inch in 24 hours come six or seven times a year. Four to 15 inches of rain falls in a 48-hour period about once every 2 years in large storms. These rains can occur in any month but are more likely during the hurricane season (AugustNovember). About half the time annual rainfall is between 40 and 50 inches (fig. 5). Less than 10 percent of the time annual rainfall is less than 35 inches, which usually means a major deficiency during the normal wet season and drought.

The cumulative departure from average and the 10-year running average of rainfall shown in figure 6 shows that at this time of writing (1967) the island may be entering a period of deficient rainfall. With the exception of a few years in the late 1940 's and early 1950 's, rainfall in the past 30 years has been below average. There has been a long-term decline of about 10 inches in annual rainfall since the peak of the surplus rainfall period in the early 1930 's. The most severe droughts of record occurred in 1964 and 1967 , when but 27 and 24 inches of rain fell, respectively.

Areal distribution of long-term rainfall, shown in figure 7 ( see letter "a "), is controlled by topography and the prevailing easterly to northeasterly winds. However, individual storms may or may not show the effects of orographic control or prevailing winds and the areal distribution of the storms can be very irregular (fig. 7--letters "b" to "f").

\section{Soil Moisture}

The soil zone over most of St. Thomas is not more than 1 foot thick. Where of sufficient thickness it has, however, the unique property of absorbing large volumes of water--as much as 12 inches in 24 hours (R. Scott, SCS, oral commun.,
1963). Examination of the soil zone when dry shows it to be coarsely granular, owing to clumping of clay and silt particles. Prolonged saturation is necessary before the granules break down. As a result, the soil has a high permeability until well saturated, but, once saturated, it becomes poorly permeable and retains water in the pore spaces between particles and rejects any excess.

Observations during rainstorms indicate that the typical soil zone will absorb about 2 inches of water before some water is rejected or moves to the underlying bedrock. Fully saturated, the soil will probably retain 3 inches of water per foot of depth.

The capacity of the soil to hold large volumes of water, together with infrequent major rainstorms and a high evapotranspiration rate, seriously reduces ground-water recharge and storm runoff.

\section{Evapotranspiration}

Most of the water trapped in the soil zone returns to the atmosphere by evaporation or transpiration by plants (evapotranspiration). On St. Thomas this process is active throughout the year, and 90 to 95 percent of the rainfall is returned to the atmosphere. The tendecy of the soil to granulate is also conducive to evaporation. As water is evaporated from the surface of a saturated tight soil, the soil again becomes granular and exposes the soil at depth to the circulation of air. Consequently, further rapid evaporation of soil moisture results.

Transpiration is a major means of water loss from the soil zone and also from the upper part of the aquifer, if the water table is near the land surface. Grasses and shallow-rooted plants can transpire water only from the upper few feet of the soil zone, but many kinds of trees, such as deeprooted false tamarind, transpire water from depths of more than 20 feet.

The effects of evapotranspiration may be seen in the channel of Bonne Resolution Gut below the gaging station. The gut flows in a predominantly bedrock channel a few feet wide for about 1,500 feet before reaching the alluviated embayment at Dorothea Bay. Base flow of the stream, when less than 10,000 g pd (gallons per day), disappears in this reach. The loss is attributed principally to transpiration by the dense growth of brush and 


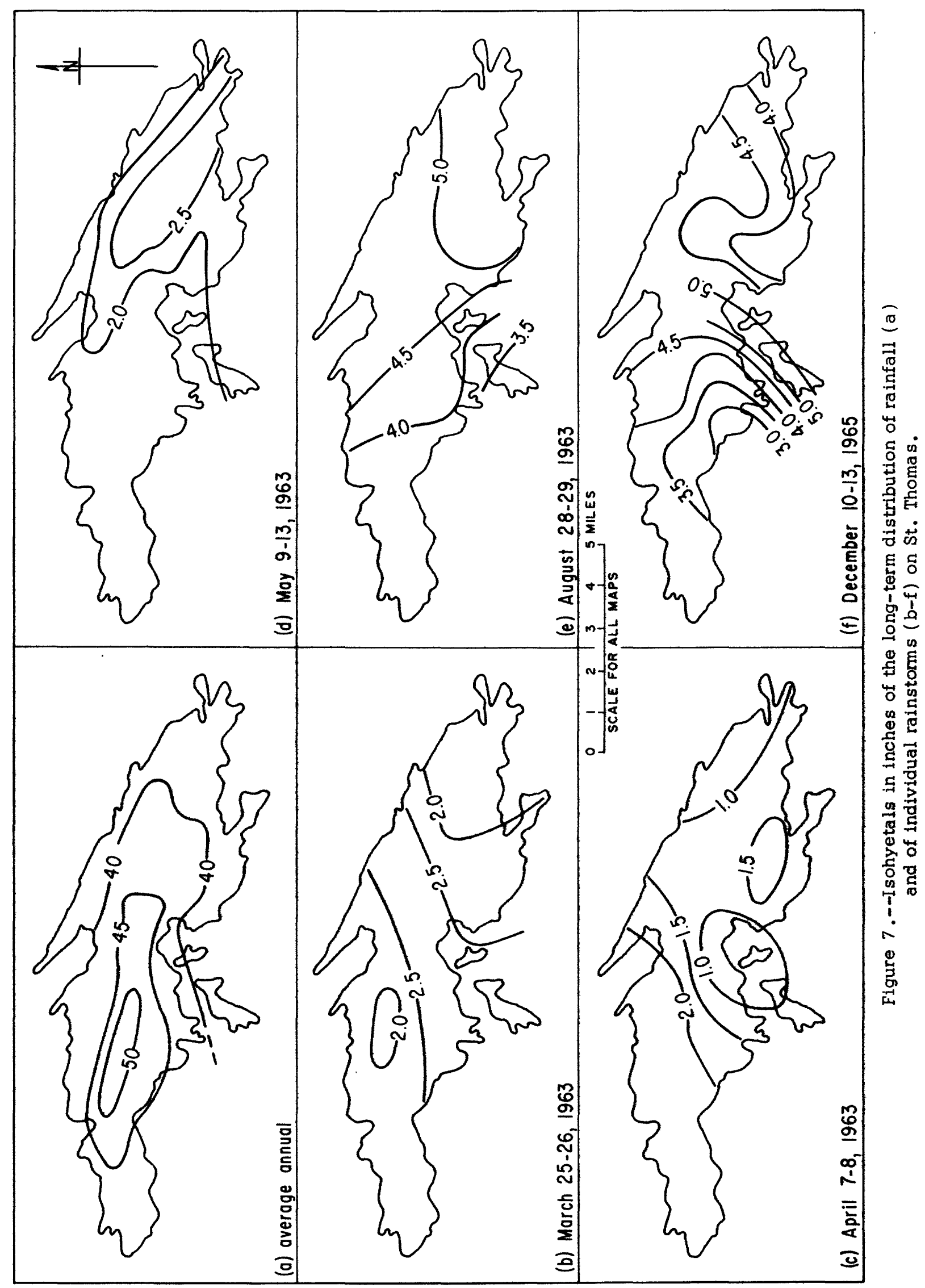


trees bordering the stream. From the appearance of the vegetation in a dry period, only the vegetation in a strip about 100 feet wide with a total area of about 3 acres benefits from the stream. A minimum water loss of $10,000 \mathrm{gpd}, 3.6 \mathrm{million}$ gallons annually, would indicate an evapotranspiration rate of 1.2 million gallons per acre per year, or 44 inches.

Bowden ( 1968 ) computed monthly potential evaporation and soil-moisture deficiency at six stations on St. Croix using the method devised by C. W. Thornthwaite. Potential evaporation ranged from 58 to 69 inches and averaged 62 inches per year. Actual evapotranspiration (derived from potential evapotranspiration and change in soil moisture) ranged from 41 to 46 inches and averaged 43 inches per year. Bowden's data shows a soilmoisture deficiency 9 to 11 months of the year at the different stations. Surplus soil moisture occurred only in the months of September to November. The authors believe that conditions are similar in St. Thomas.

\section{$\underline{\text { Streamflow }}$}

The 5 to 10 percent of rainfall not returned to the atmosphere by evapotranspiration from the soil zone either recharges the ground-water reservoir or runs off to the sea. Annual runoff in a time of average rainfall ranges from about 2 to 8 percent of the rainfall.

Most stream channels on St. Thomas are dry and carry only storm runoff. Only two streams on the island have perennial reaches. In these reaches, about one-half to three-fourths of the flow is storm runoff, and the remainder is base flow (groundwater outflow to the streams).

From 0.5 to 2 inches of water annually reaches the sea as storm runoff. The amount of storm runoff varies from basin to basin, depending upon topography, soil moisture, exposure, and vegetation. Base flow of the streams with perennial reaches, while often equal in volume to storm runoff, seldom reaches the sea. The flow usually infiltrates into alluvial deposits in the lower reaches of the streams.

\section{Ground Water}

From 0.5 inch to as much as 5 inches of the rainfall annually infiltrates the soil and rocks to reach the ground-water reservoir. Water in the ground-water reservoir or aquifer moves by gravity toward the sea. Where the water table is intercepted by the land surface, water is discharged as a spring or as base flow to a stream. Where it is near the land surface, such as along stream channels and in coastal embayments, large volumes of water are transpired by plants whose roots tap the ground-water reservoir. The transpiration by plants directly from the water table is so great that only minute quantities of ground water ever reach the sea, either as streamflow or as seepage directly through the soil and rocks.

Fresh- Salt-Water Interface

Fresh water in the aquifers along the coast is in contact with salt water in a dynamic system. So long as water levels grade seaward, fresh water will discharge to the sea at the shore. During times of ground-water recharge, the freshwater lens thickens, displacing the underlying, heavier, salt water downward and seaward. During times of no recharge, the fresh-water lens thins, as ground water discharges to sea. Salt water, which moves into the normally fresh zone of water during times of no recharge, is not entirely flushed out by fresh water when recharge occurs. Some remains behind, where it mixes with influxing fresh water. The interface zone of brackish water is thick where fluctuations in the size of the fresh-water lens are large.

In some coastal areas, where the fresh-water lens is thin because of lack of rainfall or unfavorable topographic or geologic factors, the underlying interface zone may extend inland several hundred feet at depths of but a few feet below the water table.

The balance between salt water and fresh water in coastal aquifers is delicate and can easily be disrupted by man's quest for water. Salt-water encroachment can readily result by removing more water from the fresh-water lens than is being replaced by recharge or by pumping a well at an excessive rate, in which case the fresh-water head is lowered, and movement of salt water upward or horizontally into the fresh-water zone is induced. 


\section{WATER SOURCES}

Fresh water has always been in critical supply in St. Thomas. Rain collected on roofs and stored in cisterns is still the source of water for most rural and urban domestic supplies. Before 1960 hillside rain catchments and a few dug wells were the major source of water for public supplies . Since then, desalted water has become the major source of water for public supplies, and water barged from Puerto Rico is a close second.

\section{Charlotte Amalie}

Charlotte Amalie has a dual public water system. Fresh water is used for drinking and general household needs, and salt water is used for sanitary and fire-control purposes. The fresh-water supply, obtained from salt-water distillation plants, hillside rain catchments, and a well, is supplemented by water barged from Puerto Rico. Potable water use and the sources of the water in figure 8 not only show the increasing demand for water but also the shift in sources of the water. In the late 1950 's, with the exception of 1957, a drought year, catchments were the major source of water. Barged water became the major source of supply in the early 1960 's, but by the late 1960's, desalted water became the principal source of supply.

Nearly all buildings, both private and public, in Charlotte Amalie have roof catchments and cisterns. In 1926, before the establishment of a public water system, about 200 private and 17 public dug wells were in use in the urban area. Since then most of the wells have been abandoned because of sewage and salt-water contamination. Some of the salty water was drawn into the wells from the sea as a result of overpumping, and some of it entered the wells from leaky salt-water pipes. A few of the wells are still pumped occasionally for nondrinking domestic supplies and for construction purposes. In recent years, wells have been dug in eastern Charlotte Amalie for a supplemental water supply for the two public-housing projects . Several other wells have been dug in the same general area for water for nondrinking domestic use.

Since 1926, 18 public hillside rain catchments have been constructed. Of these, 14 are connected to the urban water-distribution system.
Water is hauled from the remaining four catchments by individual users or by water haulers. The total area of the public catchments is estimated to be 24 acres, and the storage is estimated to be 14 million gallons. Reliable figures are not available on the amount of water used from any of the catchments, but total yield is estimated to be $50,000 \mathrm{gpd}$. In addition to the public catchments, four privately owned catchments are in the urban area.

A gallery well at the airport was an important source of water in the 1950's. It reportedly yielded $13,000 \mathrm{gpd}$. An attempt to increase production resulted in salt-water encroachment, ruining the well as a source of potable water.

In 1962 the first desalting plant, with a capacity of $250,000 \mathrm{gpd}$, was put into production. In 1966 a plant of 1 million gpd was put into production, and, by 1967, the start was made on a 2.5 million gpd desalting plant.

The demand for water has increased six-fold since 1960 and shows little indication of leveling off. In 1962 and again in 1966, when desalting plants were put on line, water demand increased almost overnight to absorb the increase in production. Water barging, considered a stopgap measure, has had to be continued to meet the demand.

The desalting plants reportedly will produce water at an average cost of about $\$ 1.00$ per 1,000 gallons when operating at maximum efficiency. The cost of barged water from Puerto Rico depends upon equipment used, but in 1967 averaged about $\$ 3.50$ per 1,000 gallons. Water is sold to the consumer at a cost of 50 cents per ton, about $\$ 2.00$ per 1,000 gallons. The difference between production cost and delivery cost is absorbed by the Virgin Islands Government.

\section{Rural St. Thomas}

Rooftop catchments and cisterns are still the major source of water for rural St. Thomas. During prolonged dry periods, rain water is supplemented by water hauled from public-supply points in Charlotte Amalie. Small ponds have been constructed, tapping storm runoff for irrigation water for truck gardening and drinking water for stock. Since 1962 several private wells have been drilled 


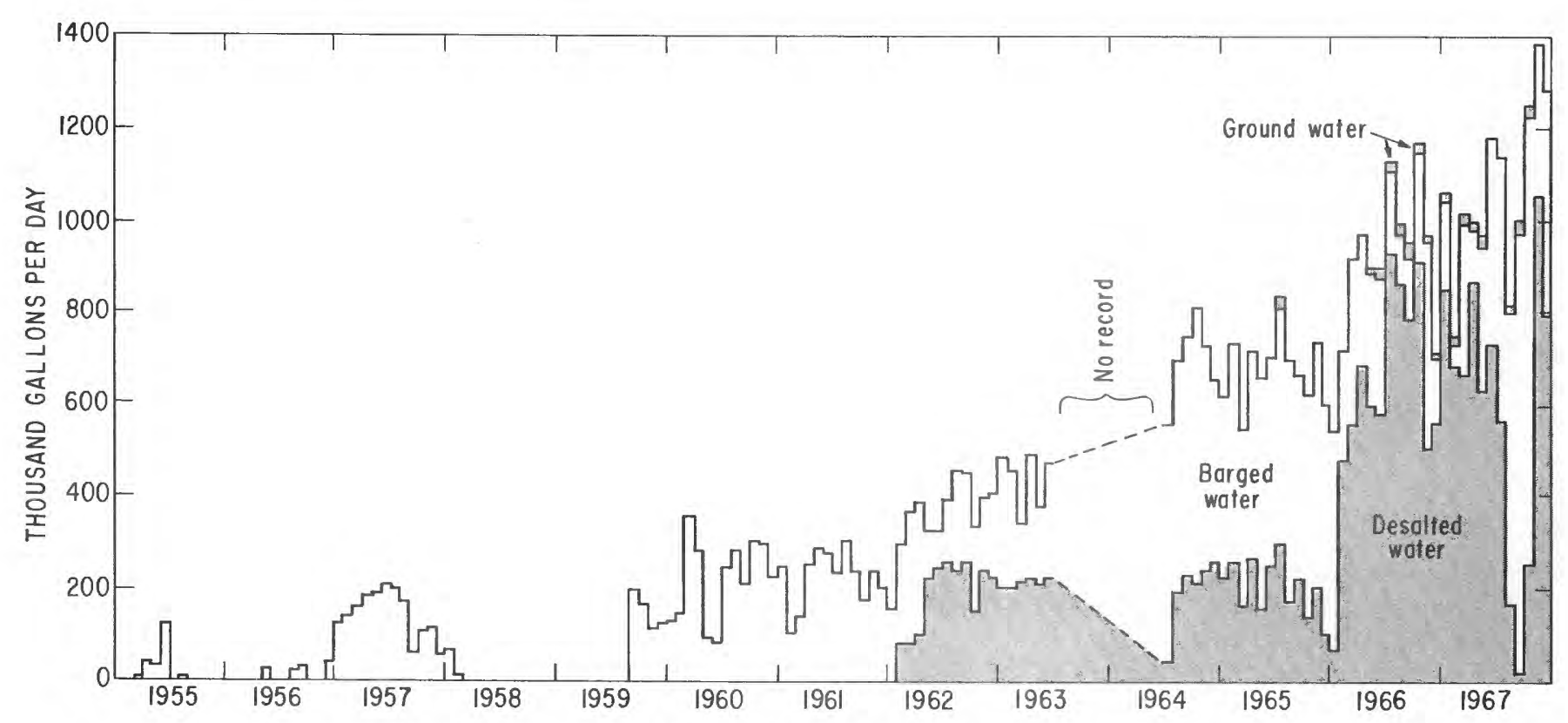

Figure 8.--Potable water use and sources for Charlotte Amalie. Unmetered water from rainfall catchments estimated to average $50,000 \mathrm{gpd}$ not shown.

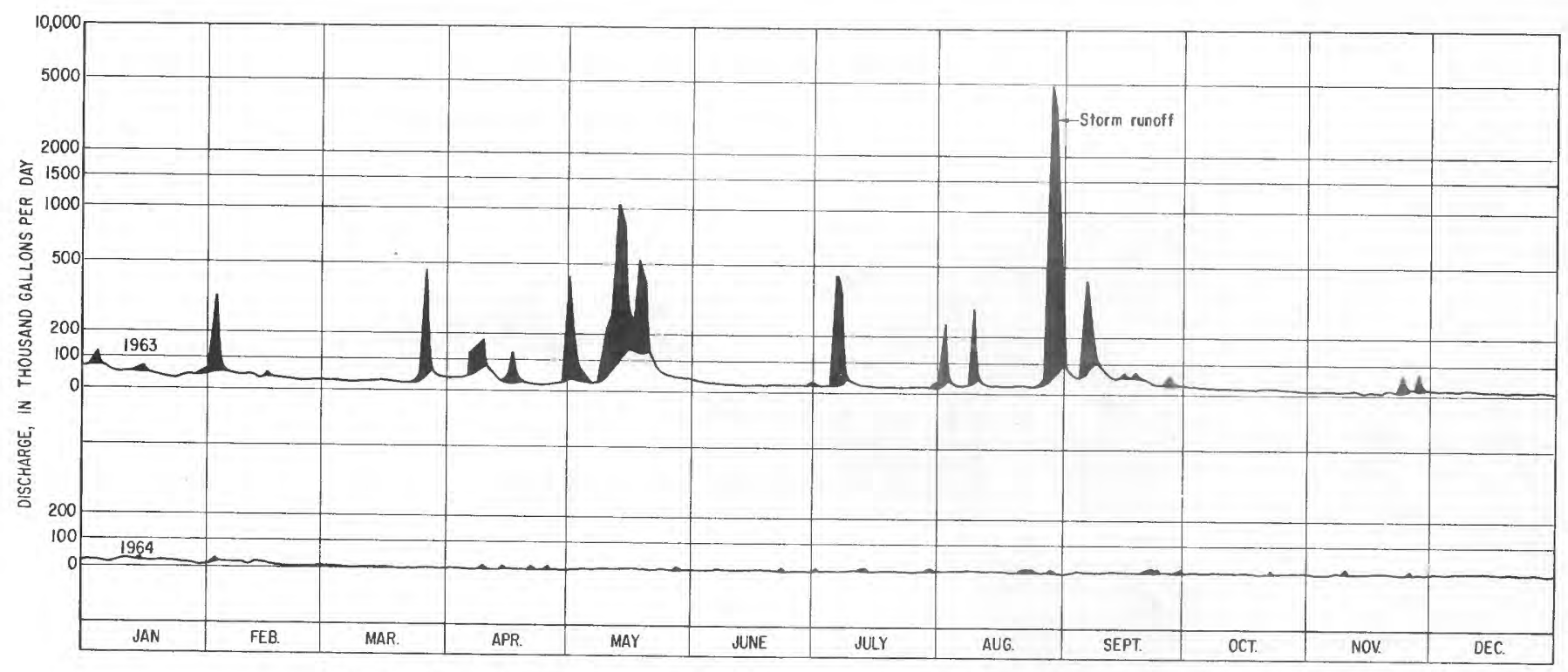

Figure 9.--Daily discharge of Turpentine Run near Mt. Zion, 1963-64. 
as supplemental sources of water for domestic use, stock, and irrigation.

\section{Natural Water Resources}

The natural water resources of the island-ground water and surface water--are the residue of rainfall after evapotranspiration. Rain, as such, is a water resource on St. Thomas, for in many places it is collected and stored for future use.

In the following pages only the "natural" water resources are discussed, and the sea is discussed only as it directly affects the natural resources.

\section{Water from Streams and Other Surface Sources}

Surface-water resources are negligible on St. Thomas. Streams are small and generally intermittent. There are no lakes, although, numerous farm ponds have been constructed. Hillside rainfall catchments for many years were an important source of water for public supply. Rooftop catchments are still the major source of water for most private homes.

During the study period, 1963-67, rainfall was above average only in 1965 . There were 2 years of extreme drought: 1964, when rainfall was 27 inches; and 1967, when rainfall was 24 inches. Streamflow in particular was greatly affected. The worst probable conditions, therefore, could be studied.

\section{$\underline{\text { Streamflow }}$}

Streams generally flow only after heavy rains. None of the streams on St. Thomas are perennial in the ordinary sense. A few spring-fed pools and short reaches of two streams flow throughout the year, but in extreme drought even these disappear.

The variability of streamflow is shown in the hydrographs, figures 9,10 , and 11 , of Turpentine Run and Bonne Resolution Gut, the only two streams that generally have some flow throughout the year.

Streams head in the volcanic rock uplands, where valleys are steepsided and stream courses have steep gradients and are commonly strewn with boulders. Near the sea, larger valleys broaden, stream gradients are gentle, alluvial deposits are present, and boulders are less numerous. Drainage basins are small, few being larger than half a square mile in area. Turpentine Run is the only drainage basin exceeding a square mile in area.

Historical streamflow.--Historical reports, geologic evidence, and older residents indicate that streamflow was once greater than at present.

The decline in ground-water levels and in streamflow (as noted, the discharge of ground water supports base flow of the streams and springs) is attributed to changes in land use. In the not-too-distant past much of the island was under cultivation or in grass pasture. Now it is covered by a dense growth of deep-rooted brush. The brush, which has a greater transpiration rate than grass pasture and croplands, probably intercepts a large part of the water that previously reached the ground-water reservoir and was subsequently discharged as streamflow.

Several small spring-fed streams on the south coast from the vicinity of Long Bay to Fortuna Bay and along the north coast from Santa María Bay to Water Bay (fig. 12) no longer flow. Two of the springs on the south coast reportedly flowed 5 to 10 thousand gpd each. The water from Staabi Spring ( 9 on fig. 12), was piped into Charlotte Amalie for water supply. The other, on John Dunko Estates ( 8 on fig. 12) above Crown Bay, was once considered as a potential source of water for Charlotte Amalie.

Staabi Spring still contributes a trickle of water to streamflow. Small spring-fed pools still exist at Fortuna Bay and Estate Solberg. All other springs and streams on the south coast are dry, although many have small dams built on them, indicating former flow.

Calcareous tufa, deposited by former streams, is present in nearly all water courses on the north coast between Santa María Bay and Water Bay on the north coast. At Caret Bay, until a few years ago, streamflow was reportedly perennial. Springfed pools are still used for stock watering, and one in the vicinity of Estate Barrett is used for public supply.

\section{Turpentine Run}

Turpentine Run in eastern St. Thomas drains an area of 3.4 square miles. About two-thirds of the drainage basin lies in the interior and is surrounded by high hills. Discharge to the sea is through a relatively narrow V-shaped valley, 200 


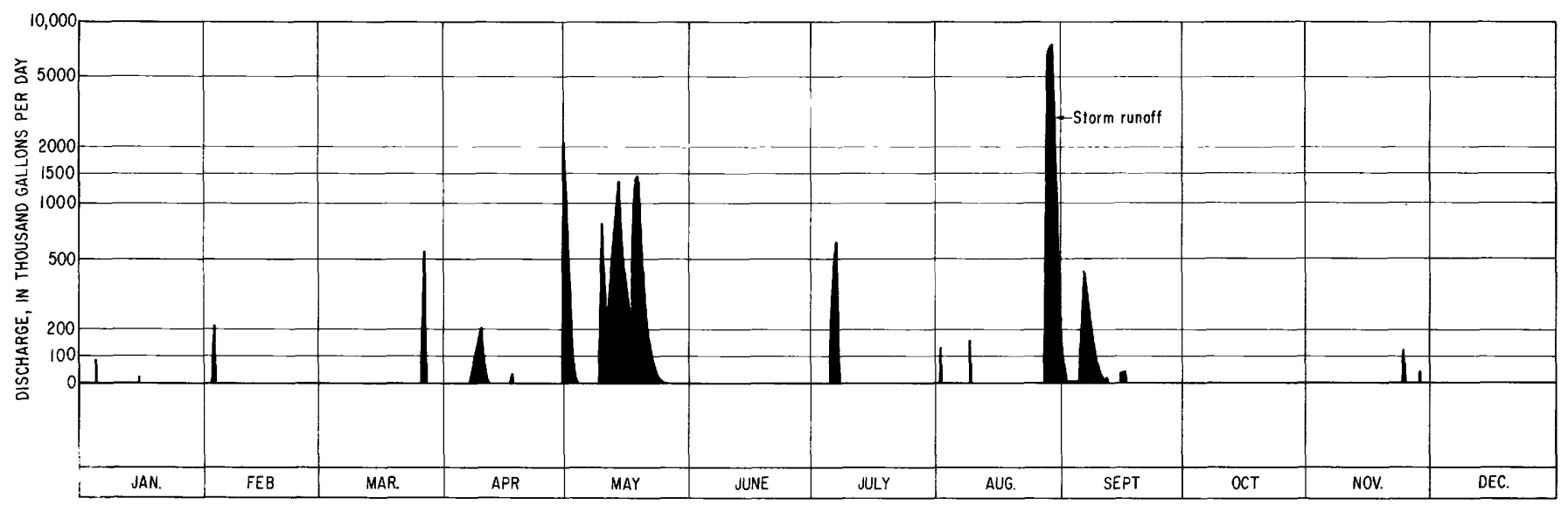

Figure 10.--Daily discharge of Turpentine Run at Mariendal 1963. All flow storm runoff. No flow in 1964.

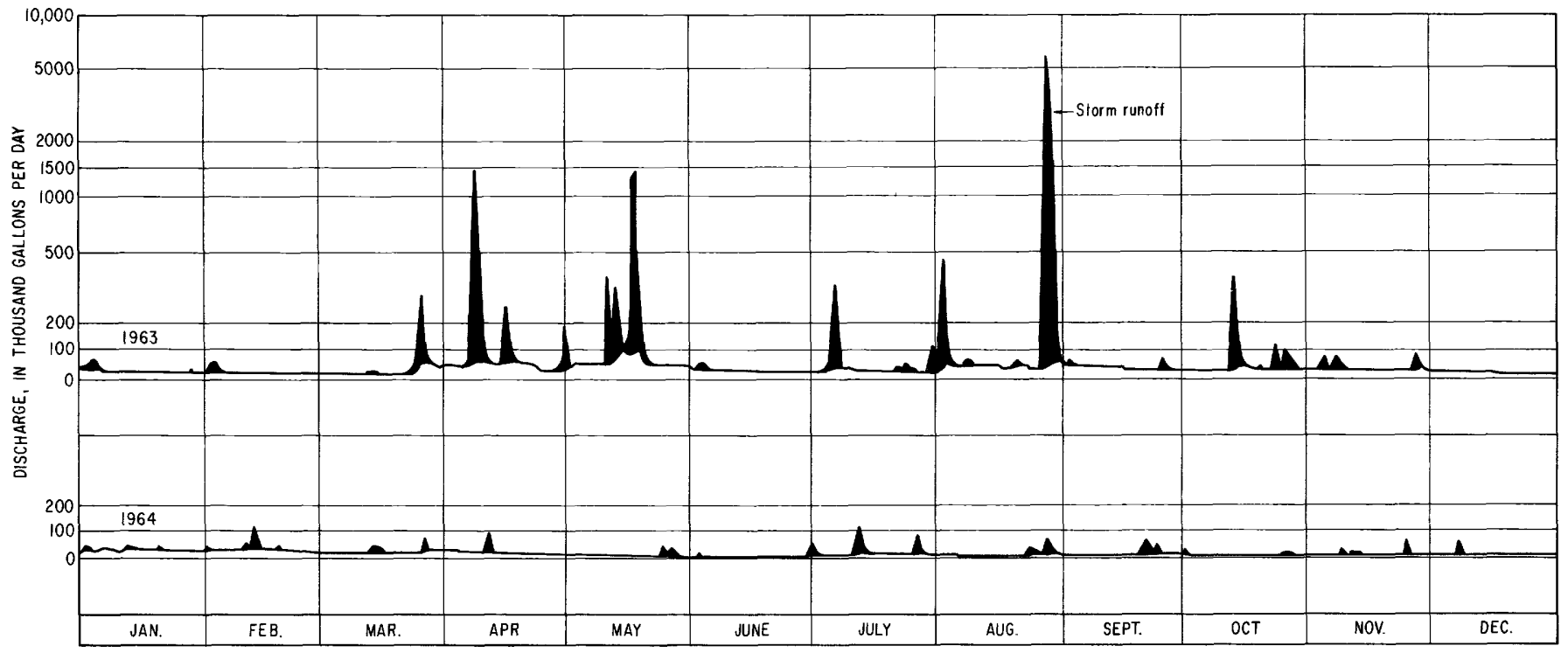

Figure 11.--Daily discharge, Bonne Resolution Gut at Bonne Resolution, 1963-64. 
feet wide at its narrowest place. The valley widens as it approaches the sea, where it empties into Mangrove Lagoon. About three-fourths of a mile from the sea a tributary valley drains a $0.5-$ square-mile subbasin.

\section{Turpentine Run near Mt. Zion}

The flow of Turpentine Run has been measured at the site of the Mt. Zion gage from time to time since 1920. At this point the stream drains a basin of 2.3 square miles. Flow from the basin is highly variable and is predominately storm runoff. Base flow (ground-water outflow) of the stream is meager and, at times, ceases altogether. It did not flow for 8 months in 1921 (Johnson 1936) and for 3 months in 1965 and probably has not at other times.

Discharge during 1958-62 was calculated on a daily basis, using rainfall at Estate Fort Mylner in conjunction with a rainfall-runoff ratio based on 1963 rainfall-runoff and stage recession of 1963 runoff. Discharge from 1963-67 was determined by the stage-discharge relation of a continuous recording gage established in late November 1962 . Figure 13 presents the relation of monthly and annual discharge to monthly and annual rainfall. The rainfall-discharge relation is presented in a different manner in figure 14. Scatter in the monthly relation is caused by antecedent rainfall and soil-moisture conditions in the basin.

The annual discharge of Turpentine Run is a small percentage of the total rainfall on the basin (table 2 ). In a year of near-average rainfall, discharge is less than 2 percent of the rainfall on the basin. The lack of runoff is attributed in part to high evapotranspiration and, at times, lack of ground-water contribution from the greater part of the upper basin to base flow of Turpentine Run. In extremely dry periods all ground-water is discharged through a zone of hydrothermally altered rocks at Mt.Zion directly to the alluvium and bedrock aquifer in the lower basin.

Base flow.--Turpentine Run had only base flow about 90 percent of the time during 1963-67. Except for the drought years of 1964 and 1967, base flow was less than one-third of the total annual discharge. Base-flow contribution in 196364 is shown by the unshaded area in the hydrograph in figure 9. The 10-percentile line of the duration curves in figure 15 is essentially the dividing line between base flow and storm runoff.
Table 2.--Annual discharge, Turpentine Run near Mt. Zion

\begin{tabular}{l|c|c|c}
\hline Year & $\begin{array}{c}\text { Flow, } \\
\text { million gallons }\end{array}$ & $\begin{array}{c}\text { Rainfall, } \\
\text { inches }\end{array}$ & $\begin{array}{c}\text { Runoff, percent } \\
\text { of rainfall }\end{array}$ \\
\hline $1958 *$ & 34.5 & 47.02 & 1.83 \\
$1959 *$ & 2.9 & 29.68 & .34 \\
$1960 *$ & 290.0 & 71.34 & 10.20 \\
$1961 *$ & 24.3 & 48.46 & 1.25 \\
$1962 *$ & 21.4 & 41.10 & 1.30 \\
1963 & 27.3 & 43.75 & 1.56 \\
1964 & 1.5 & 28.05 & .13 \\
1965 & 32.9 & 42.83 & 1.92 \\
1966 & 19.8 & 39.88 & 1.24 \\
1967 & 3.0 & 22.91 & .33 \\
\multicolumn{3}{|c}{ Discharge computed from daily rainfall. }
\end{tabular}

Flow in Turpentine Run during 1964, 1967, and the first 10 months of 1965 was almost entirely base flow. Discharge seldom exceeded 15,000 gpd and more than half the time was less than $5,000 \mathrm{gpd}$.

During 1963 and 1966, when rainfall was near normal, base flow was as large as 90,000 gpd and as small as 4,000 gpd. Average base flow was about $27,000 \mathrm{gpd}$ in 1963 and 1966 .

Monthly rainfall of about 4 inches is necessary to maintain base flow. When rainfall is less, base flow declines sharply. Once base flow has begun to decline, rainfall in excess of 4 inches for 2 or 3 consecutive months is necessary to reverse the downward trend, as shown by comparing monthly rainfall and discharge during the latter part of 1965 ( fig. 13).

Storm runoff.--During'periods of near-normal rainfall, storm runoff contributes the greater part of the total annual discharge. However, storm runoff prevails only a few days each year. Storm runoff in 1963 was 65 percent of the annual discharge. Nearly 40 percent of the annual discharge occurred in 4 days, the result of one storm of 4 inches in the upper basin.

Two curves drawn through the points plotted in figure 16 are related to antecedent storm runoff. One curve passes through points where storm runoff had occurred in the previous 15 days, whereas the other curve passes through points where storm runoff had not occurred in the previous 15 days. The curves, in a crude way, indicate the quantity 


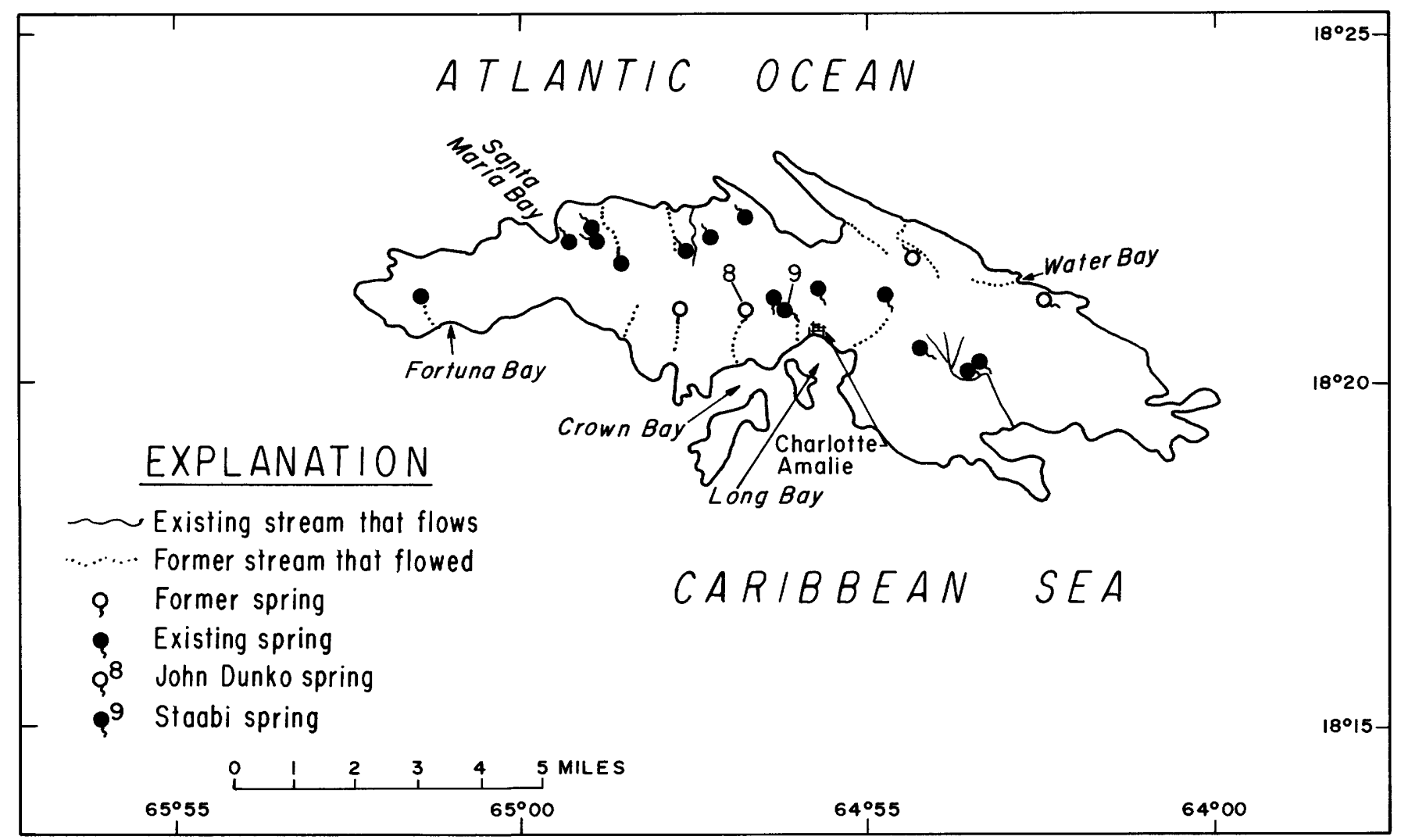

Figure 12.--Existing and former streams and springs on St. Thomas. Numbered springs are refered to in text.

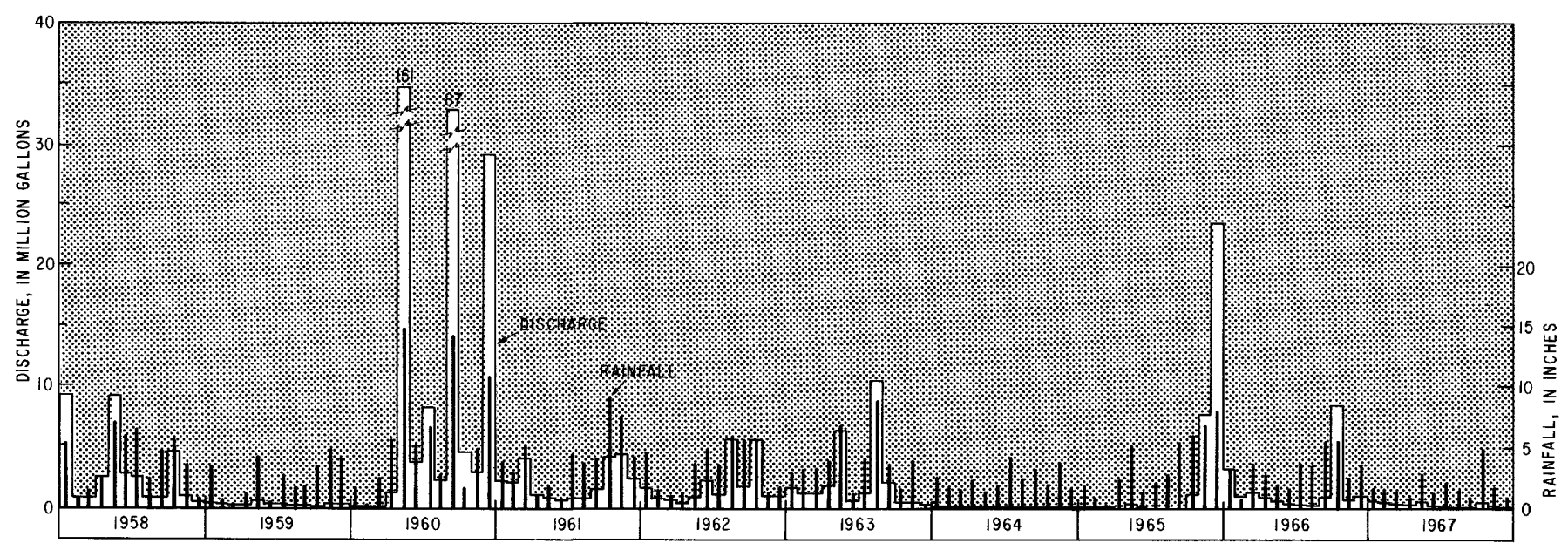

Figure 13.--Monthly discharge of Turpentine Run near Mt. Zion and monthly rainfall at Fort Mylner, St. Thomas. Discharge for 1958-62 computed from rainfall. 


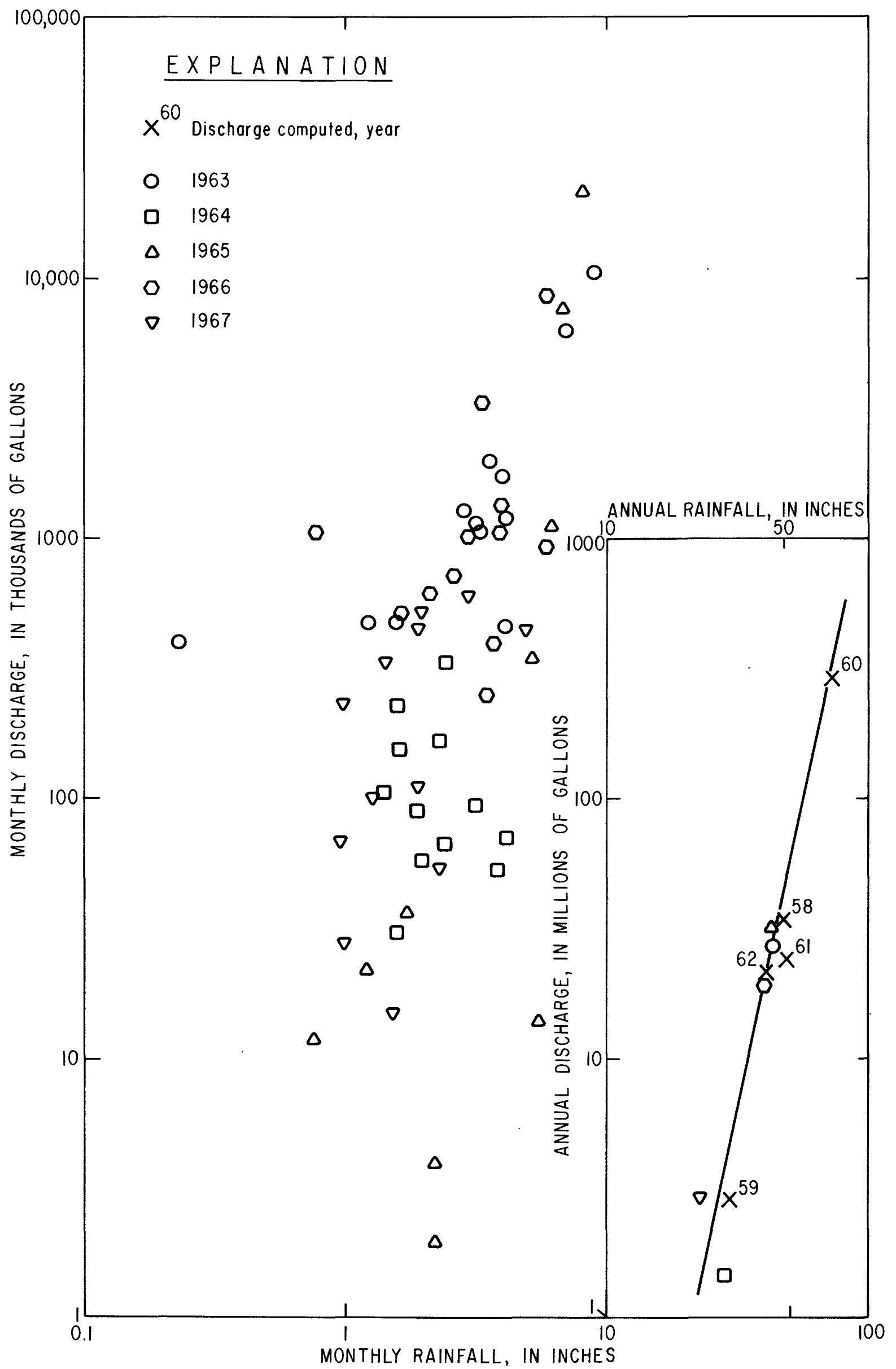

Figure 14.--Monthly and annual rainfall and discharge of Turpentine Run near Mt. Zion. 


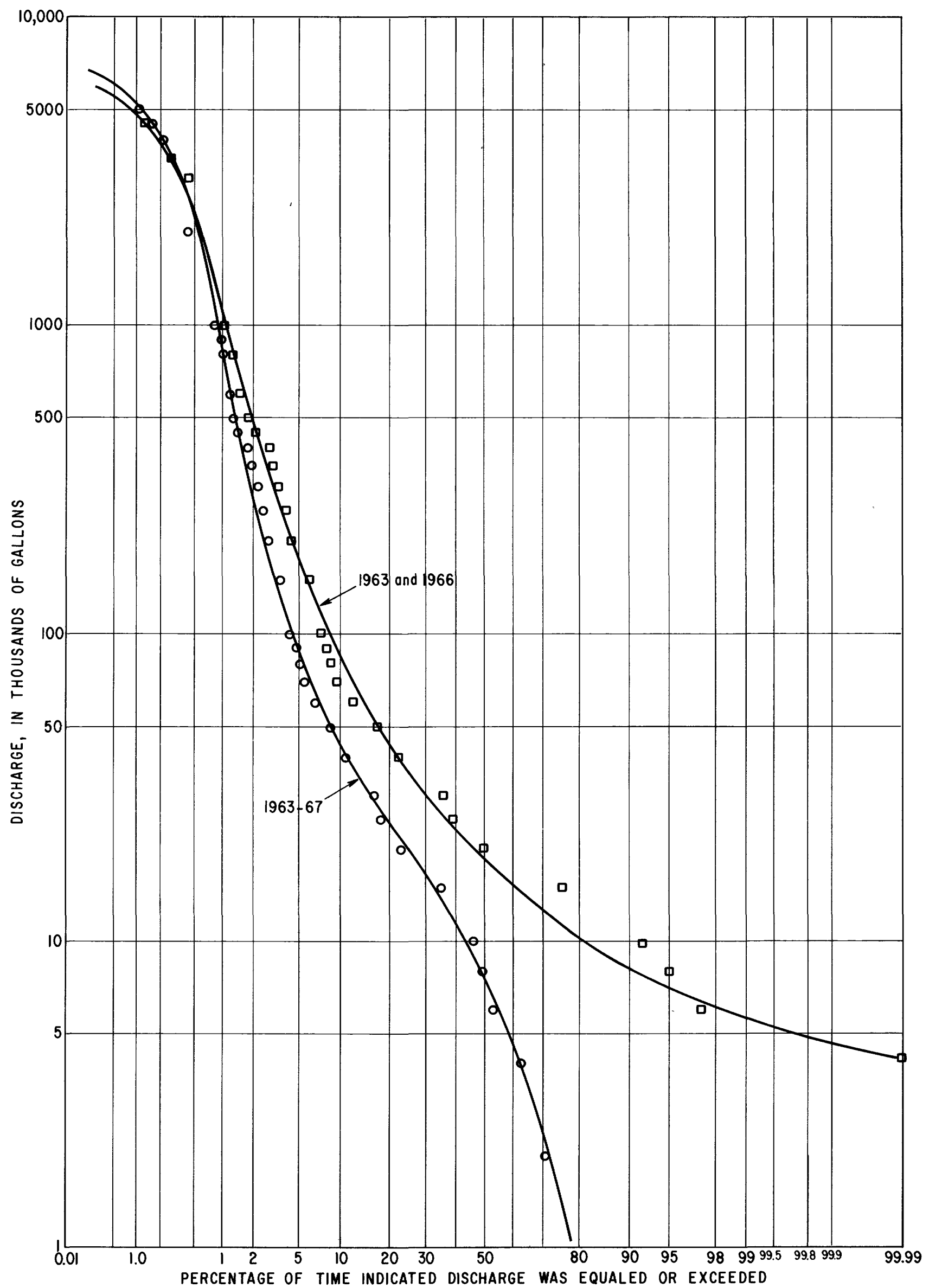

Figure 15.--Flow-duration curves of Turpentine Run near Mt. Zion, 1963-67 and 1963, 1966.

18 


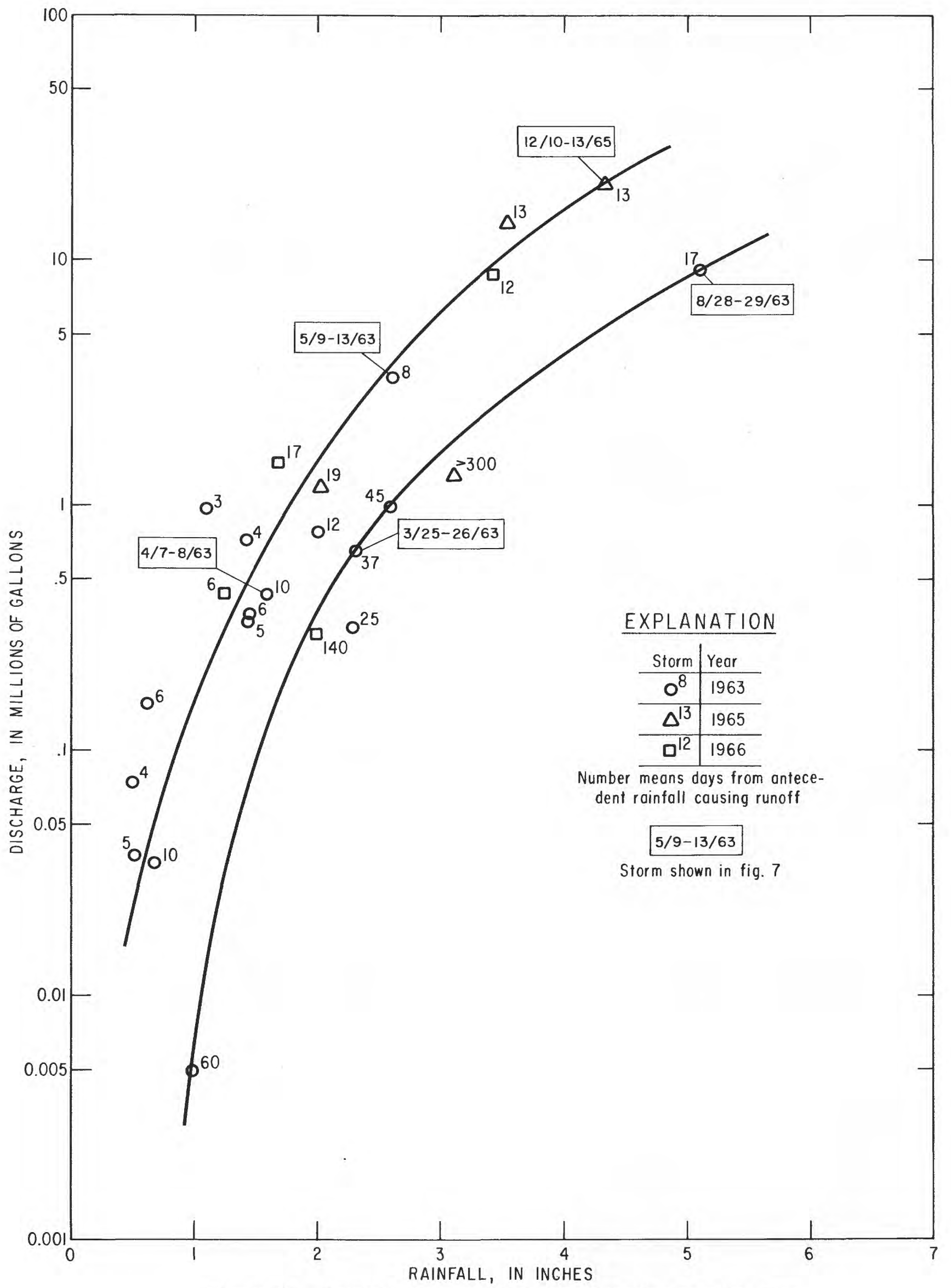

Figure 16.--Rainfall-storm runoff of Turpentine Run near Mt. Zion. 
of water recharged to the aquifers, evaporated, transpired, and needed to replace soil moisture. Maximum runoff from an individual storm was 20.5 million gallons $(8.7 \mathrm{mg} / \mathrm{sq} \mathrm{mi})$ from the storm of December $10-15,1965$, when 4.3 inches of rain fell on the watershed. Runoff on this occasion was more than twice that from a 5.1-inch rain on the watershed August 28-29, 1963. The great difference in runoff was probably related in part to rainfall intensity but mostly to antecedent soilmoisture conditions.

\section{Turpentine Run at Mariendal}

Turpentine Run at the Mariendal gage has a drainage basin of 2.8 square miles, which includes the upper basin and a major tributary that joins the main stem about 1,500 feet upstream from the gage. Alluvium underlies the stream channel to a point about 1,500 feet upstream from the gage. All base flow infiltrates this alluvium before reaching the Mariendal gage, except on the rare occasions when the alluvium is saturated to the level of the stream. Consequently, flow at the gage is almost solely major-storm runoff (fig. 10).

Base flow. --Base flow at the Mariendal gage reportedly was continuous from May 1960 to September 1962 and was observed in October and November 1962 . No further base flow occurred at Mariendal until December 1965, when there was flow for about a month between periods of storm runoff.

Storm runoff.--Storm runoff seldom lasts more than a few days, usually ceasing abruptly, owing to infiltration into the alluvium at the declining stages of the flow.

Because of the irregular distribution and intensity of rainstorms, the volume of runoff per square mile is generally not the same at Mt. Zion as it is at Mariendál. Nearly twice as much runoff per square mile has been recorded at Mariendal. However, flows as great as $100,000 \mathrm{~g}$ pd recorded at Mt. Zion never reached the Mariendal gage, owing to infiltration losses.

Maximum runoff from an individual storm was 34 million gallons ( $12 \mathrm{mg} / \mathrm{sq} \mathrm{mi}$ ) between December 10 and 15, 1965--the result of a series of rains totaling about 4.3 inches over the watershed. Runoff per square mile was nearly twice that at the Mt. Zion gage.

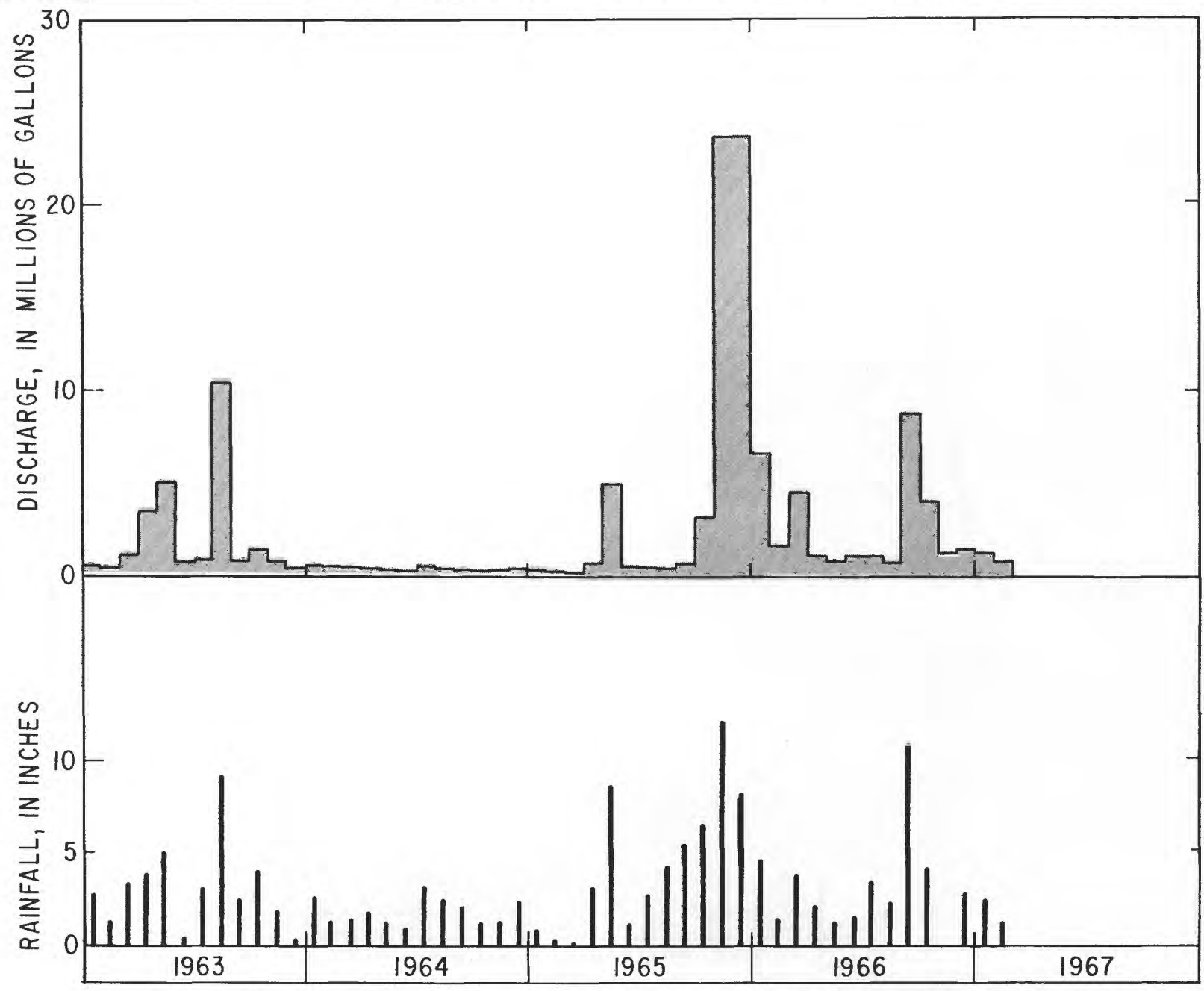

Figure 17.--Monthly discharge of Bonne Resolution Gut and monthly rainfall at Dorthea Agicultural Station. 


\section{Turpentine Run downstream of Mariendal}

From the Mariendal gage to the sea streamflow is, with rare exceptions, limited to storm runoff. Base flow from the upper part of the basin, when it does reach the Mariendal gage, usually infiltrates into the alluvium before it reaches the sea. However, base flow to the sea occurred for a short time in late 1965, when the alluvium was saturated to the base level of the stream.

\section{Bonne Resolution Gut}

Bonne Resolution Gut drains a small basin on the north coast of St. Thomas. The drainage basin is typical of the steep-gradient valleys extending from the central ridge to the sea, except that the basin is predominantly grass covered. It is the only stream on St. Thomas, other than Turpentine Run, that has perennial flow, and, like Turpentine Run, it is perennial for a reach of about 1,000 feet in the middle of its course. Flow is maintained by ground water is suing from a series of small seeps in saprolite and weathered volcanic rock. The stream was gaged from November 1962 to March 1967 at the Virgin Islands Department of Agriculture dam and pumping station near the lower end of the perennial reach and just below the last of the seeps. Drainage area at the gage is 0.5 square mile.

Flow is highly variable and is predominantly storm runoff. Base flow is generally small but is relatively constant, although it declines slowly during dry periods. At no time during the period of record did the stream cease to flow in the reach of perennial flow.

A hydrograph of monthly discharge and rainfall is shown in figure 17 . Figure 18 presents the relation of annual and monthly rainfall to annual and monthly discharge. The scatter in the relation of monthly rainfall to discharge is attributed to antecedent soil-moisture conditions in the basin.

A summary of the relation of annual discharge to rainfall is presented in table 3 . Annual discharge is 8 to 10 percent of the rainfall in a year of average rainfall. This relatively high percentage of runoff is attributed to the northern exposure of the basin and particularly to the fact that the basin is predominantly grass covered. Both factors tend to reduce high evapotranspiration, characteristic of the south slopes and brushcovered areas of the island.
Table 3.--Annual discharge at Bonne Resolution Gut. Rainfall at Dorothea Agriculture Station.

\begin{tabular}{c|c|c|c}
\hline Year & $\begin{array}{c}\text { Discharge, } \\
\text { million gallons }\end{array}$ & $\begin{array}{c}\text { Rainfall, } \\
\text { inches }\end{array}$ & $\begin{array}{c}\text { Runoff, percent } \\
\text { of rainfall }\end{array}$ \\
\hline 1963 & 25.7 & 37.72 & 7.9 \\
1964 & 4.4 & 22.55 & 2.2 \\
1965 & 58.4 & 53.53 & 12.6 \\
1966 & 32.5 & 41.26 & 9.1 \\
\hline
\end{tabular}

The flow-duration curves in figure 19 are constructed from data collected from 1963-67. The curve covering the entire period of record is skewed by the prolonged drought of 1964-65. The other curve is constructed from data collected in two separate years, 1963 and 1966, when rainfall was near average. The spread in the two curves is predominantly in the base-flow range and is significant in that it demonstrates the relatively small amount of storage in the saprolite and bedrock aquifer available for contribution to base flow. The zone between the 20 and 30 percentiles includes both base flow and minor storm runoff. To the right of the zone there is almost entirely base flow and to the left storm runoff.

Rainfall in the Bonne Resolution basin is sufficient 8 years out of 10 to maintain daily discharge exceeding $15,000 \mathrm{gpd} 80$ percent of the time.

Base flow. --Base flow usually reaches a minimum of about $10,000 \mathrm{gpd}$ in April at the end of the dry winter season. In drought years, base flow, of course, will be less. Minimum base flow of record, 2,500 gpd, was reached in March 1965 after 16 months of nearly continuous drought.

Maximum base flow occurs after major storm runoff during the rainy season, when ground-water levels are high. Base flow at these times is as large as $50,000 \mathrm{gpd}$.

Only base flow was present between 70 and 80 percent of the time during 1963-66, but, except during the 1964 drought, it contributed less than one-fourth the annual discharge. It does, however, constitute the greater part of the usable water available from the stream, as the steep gradient precludes constructing large impoundments for storing storm runoff. 


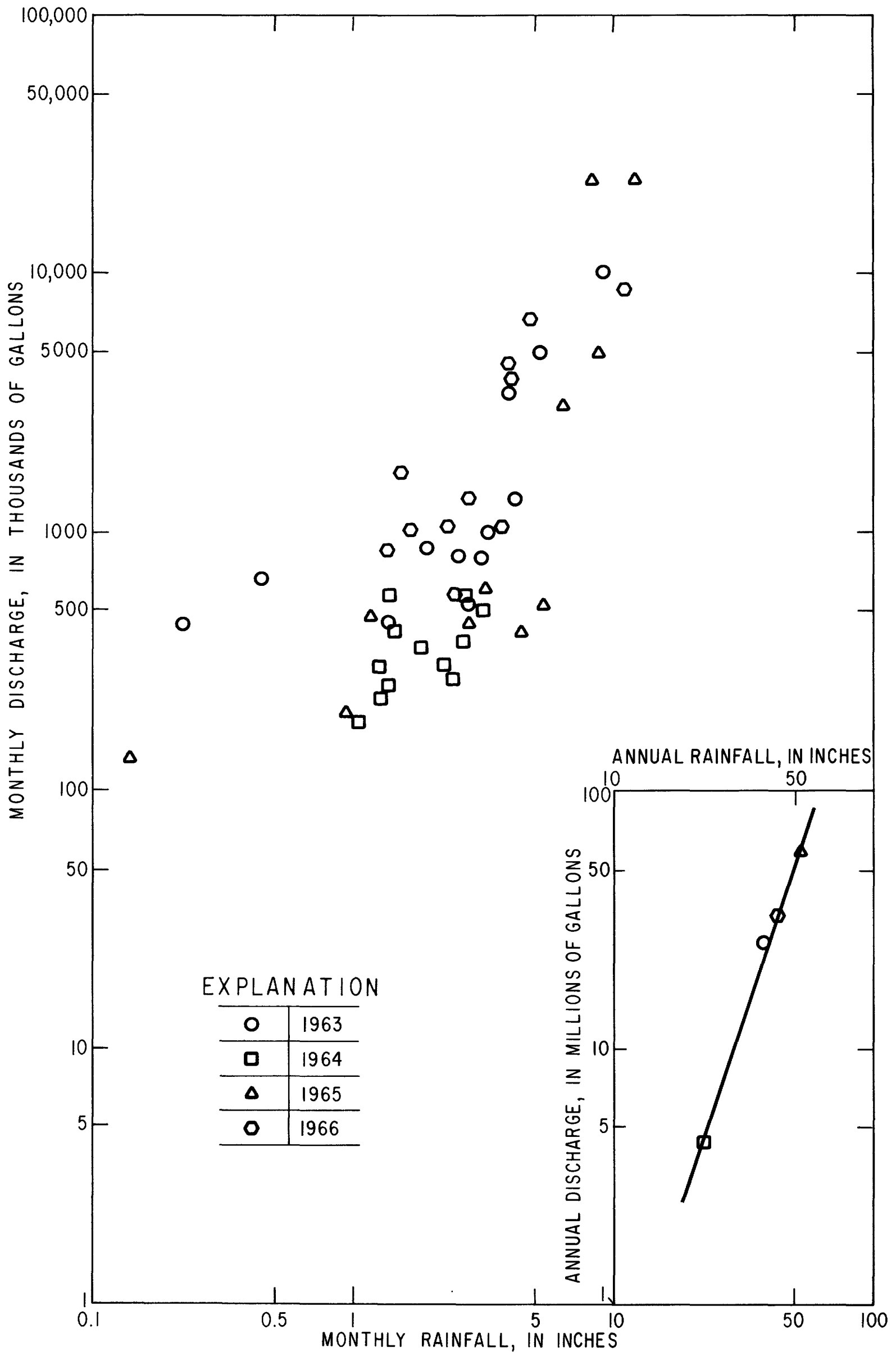

Figure 18.--Monthly and annual rainfall and discharge of Bonne Resolution Gut at Bonne Resolution. 


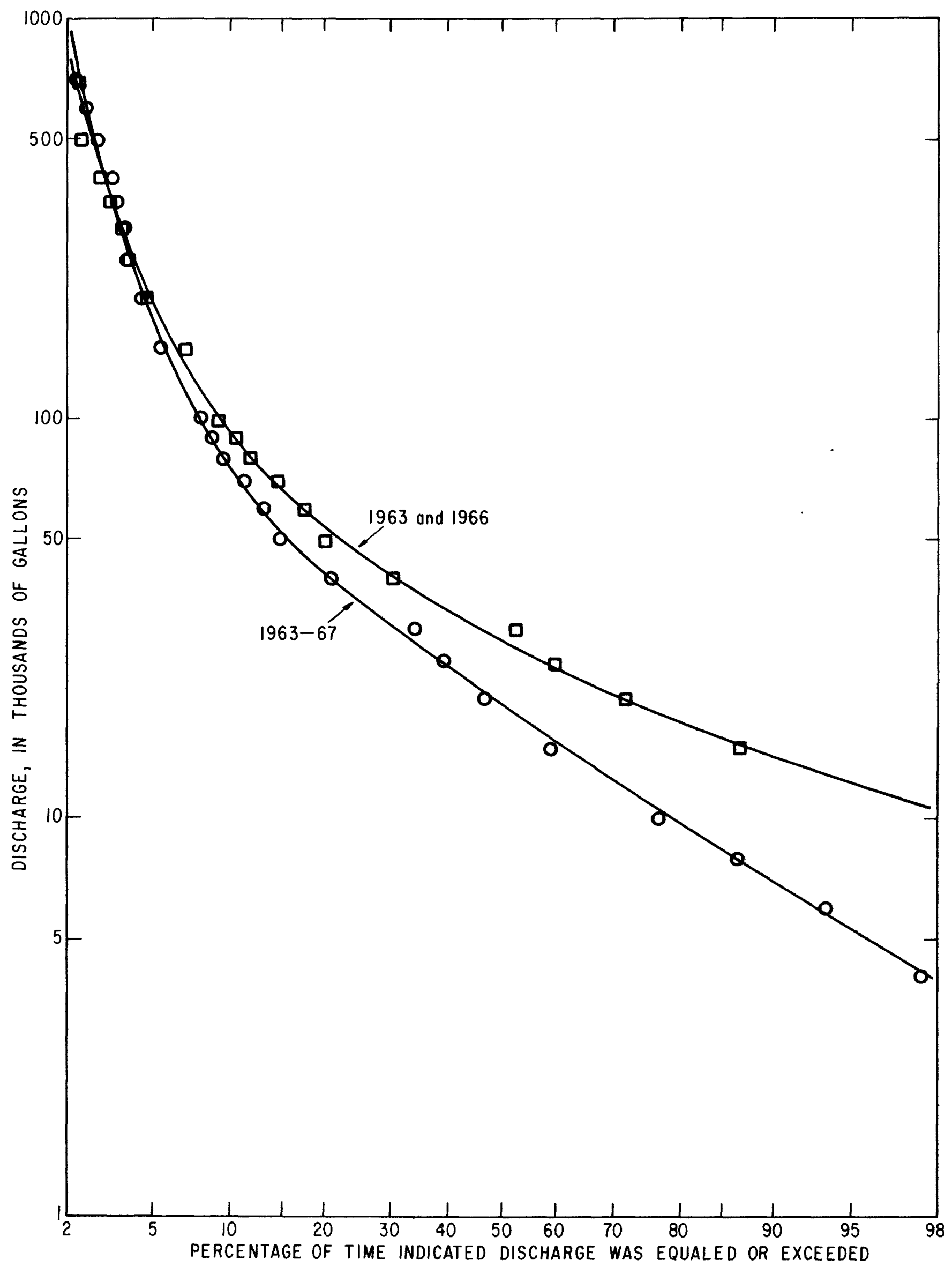

Figure 19.--Flow duration curves of Bonne Resolution Gut at Bonne Resolution, 1963-67 and 1963, 1966. 
Storm runoff. - - The steep gradients of the basin are not only conducive to rapid runoff of heavy rainfall but also promote runoff from rainfall as light as half an inch. Storm runoff constitutes the greater part of the annual discharge of the stream. In 1963, storm runoff accounted for about 70 percent of the total discharge and, in 1965, a year of abnormal rainfall distribution, about 90 percent. Maximum runoff from an individual storm was about 12 million gallons in 6 days after a 4 -inch rain in December 1965. Maximum 1-day discharge was about 6 million gallons on August 28, 1963, also the result of a 4 -inch rain.

Storm runoff from individual storms commonly exceeded 10 percent of the rainfall on the basin and was as great as 30 percent of some storms during the last few months of 1965, when rainfall was excessive and soil-moisture demands were low.

The rainfall-runoff relation for individual storms is shown in figure 20. Two curves are shown--one in wet and the other in dry periods.

Water use.--Water is pumped from behind a retention dam in the stream to a small storage tank, from which it is distributed by gravity for the irrigation of truck crops. The diversion is on a demand basis, and maximum demand is in the dry season, when streamflow is usually at its lowest. Consequently, the entire flow is often diverted for several days. If streamflow is sufficient, the maximum diversion is about $13,000 \mathrm{gpd}$. Annual irrigation diversion is given below :

\begin{tabular}{l|r}
\hline Year & \multicolumn{1}{|c}{ Gallons } \\
\hline 1963 & 845,000 \\
1964 & 986,000 \\
1965 & $1,080,000$ \\
1966 & 915,000
\end{tabular}

$\underline{\text { Floods }}$

Flash floods are not uncommon in St. Thomas. In the past, damage from flooding has been minimal because the stream channels and flood plains had not been encroached upon except in the city of Charlotte Amalie.

Much of the flooding in Charlotte Amalie has been the result of canalization of the guts (stream channels) flowing through the city. As often as not, flooding has been the result of the guts be- coming clogged with debris rather than the lack of discharge capacity of the unclogged channels. Flooding in part of downtown Charlotte Amalie in October of 1965 was as much due to plugging of guts by debris as to the intensity of the rainfall. The rainstorm itself was but 1 inch in 2 hours.

Flood of May 8, 1960.--The so-called Mother's Day flood was the worst flood of record. In the 2 days preceding May 8, 1960, the island received about 3 inches of rain. On May 8 a severe thunderstorm remained near stationary over the island, and as much as 8 inches of rain was reported to have fallen in a 5-hour period. Extendsive flooding occurred along the south coast from Harry S. Truman Airport to Long Bay. The valley of Turpentine Run was flooded from the junction of the three branches at Mt. Zion in the upper basin to the sea. In the narrowest part of the valley at Mariendal water was reportedly as much as 4 feet over the highway. Elsewhere, flooding was confined to the channels and the embayments at the mouths of the steep guts.

Potential danger of flooding.--Flash floods resulting from high-intensity rainfall associated with tropical thunderstorms can hardly be avoided on a small, steep-sloped island such as St. Thomas. Because of the steep slopes, however, flooding is usually confined to the immediate vicinity of the numerous stream channels.

Observation of rainfall and storm runoff have shown that intensity of rainfall and antecedent soil-moisture conditions often have a greater influence on the stage and volume of storm runoff than the amount of rainfall. A comparison of peak stage of Turpentine Run at the gage near Mt. Zion and the 24-hour rainfall on the day of the peak stage is shown in figure 21 . The effect of soil moisture and its relation to antecedent rainfall is readily evident.

Two areas where serious property damage can result from flooding are Charlotte Amalie and the basin of Turpentine Run.

In Charlotte Amalie and the urban area surrounding the city, the natural drainageways have been encroached upon, canalized, and in some areas obliterated by buildings and roadways. Storm runoff in many places has nowhere to go except down roads or between and through buildings. Increased urban development in the hills above the city will cause more rapid storm runoff and accompanying 


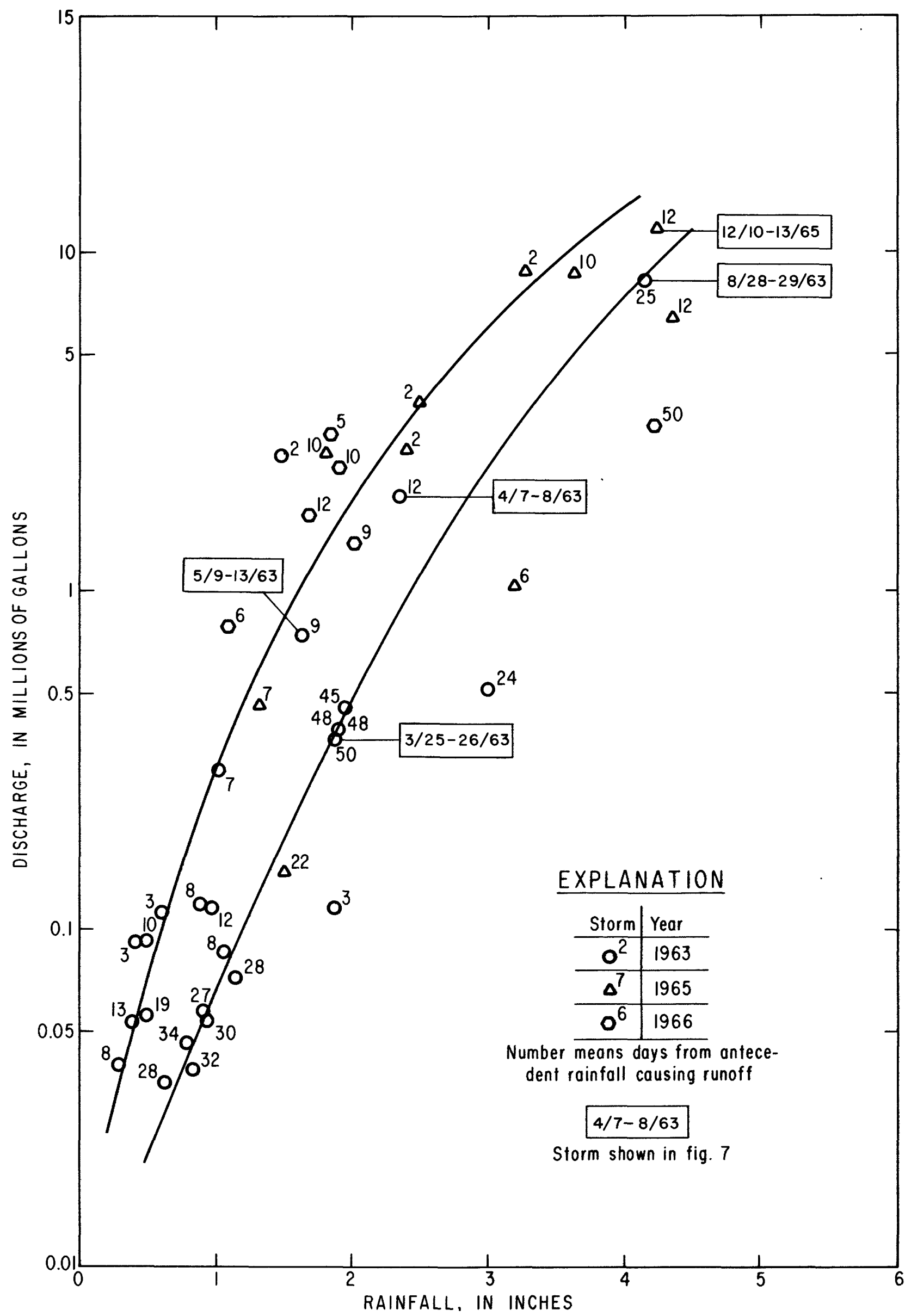

Figure 20.--Rainfall-storm runoff of Bonne Resolution Gut at Bonne Resolution. 


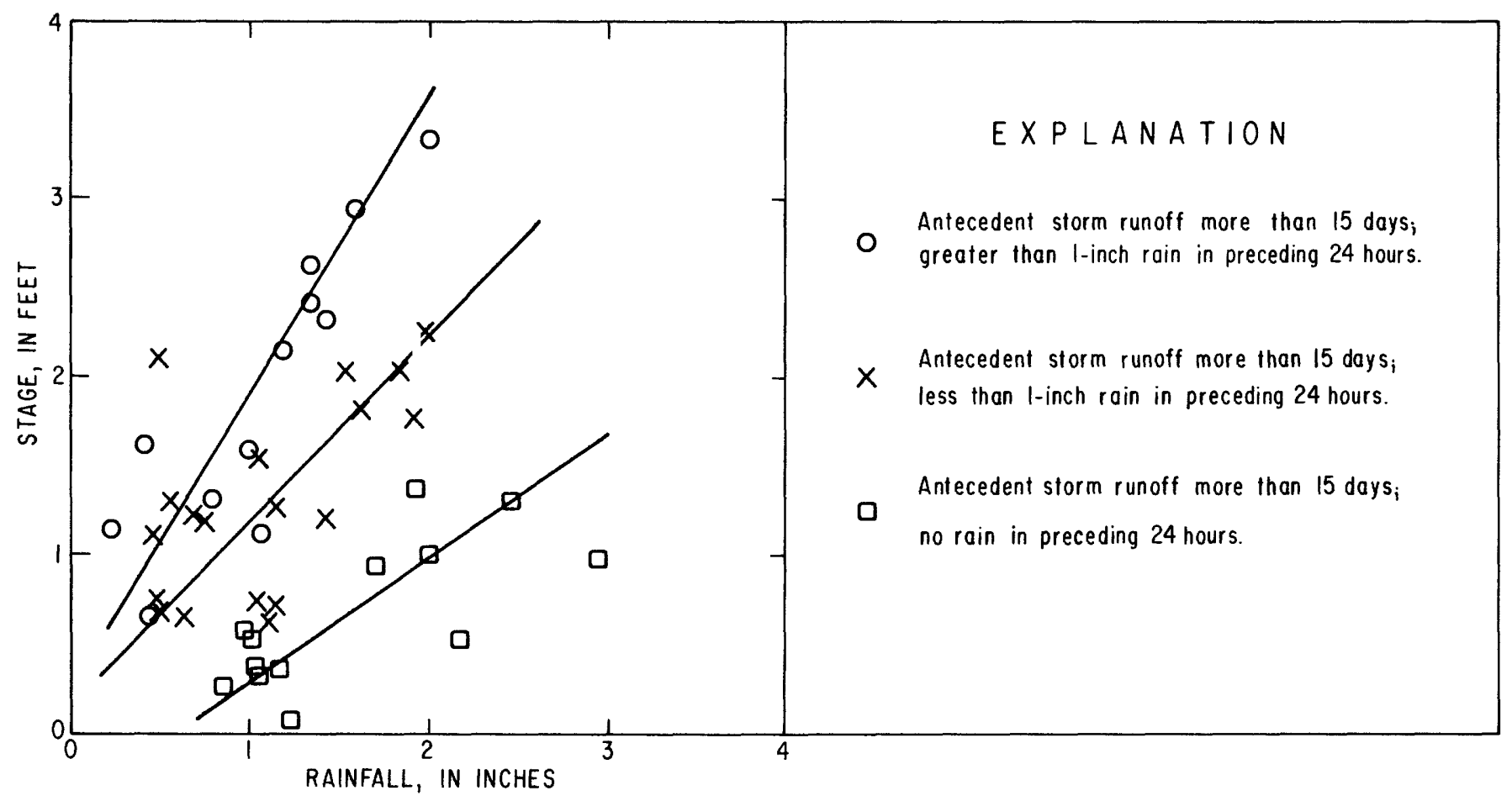

Figure 21.--Rainfall-peak stage relatıonship of lurpentine Run near Mt. Zion. Rainfall at National Weather Service gage at Fort Mylner.

higher peaks. As runoff, of necessity, has to pass through the city proper, more frequent flooding can be expected.

Flooding is aggravated by the disposal of trash in stream channels. The trash not only reduces the carrying capacity of the stream channels but often lodges under bridges and in downtown Charlotte Amalie in the covered stream channels, causing water to back up and flood the surrounding areas.

In downtown Charlotte Amalie the carrying capacity of the canalized stream channels is further reduced where the channels pass under Veterans Drive, the waterfront road. The floors of the channels are below sea level and part of the crosssectional area of the channels is occupied by the sea thus restricting flow. Tidal fluctuation is generally less than 1 foot and so has little effect on the overall carrying capacity of the channels.

In the upper basin of Turpentine Run, the flow of the middle and left branches of Turpentine Run is diverted through a culvert about 3 feet in diameter and several hundred feet in length in order to provide parking space for a shopping center.
With the discharge capacity of the stream channel so reduced, flooding in this area, with heavy property damage, will occur.

From Mariendal to Nadir in the lower basin of Turpentine Run, the naturally narrow flood plain is being encroached upon by land fill and housing. At Nadir, flood flows are restricted by the bridge, and backwater will build up, covering the flood plain. In August 1963 and in December 1965 flood flows topped the road at the bridge, and the flood plain upstream was inundated. Upstream between Nadir and Mariendal, where the flood plain is naturally restricted in width and further restricted by land fill and building, severe flooding can be expected from relatively modest rainstorms.

Flooding at Nadir can be alleviated by increasing the stream-channel section at the road crossing. In the vicinity of Mariendal, however, there is no way to prevent flooding.

Ponds

Farm ponds play a useful role as a source of water for stock and in a few places for the irriga- 

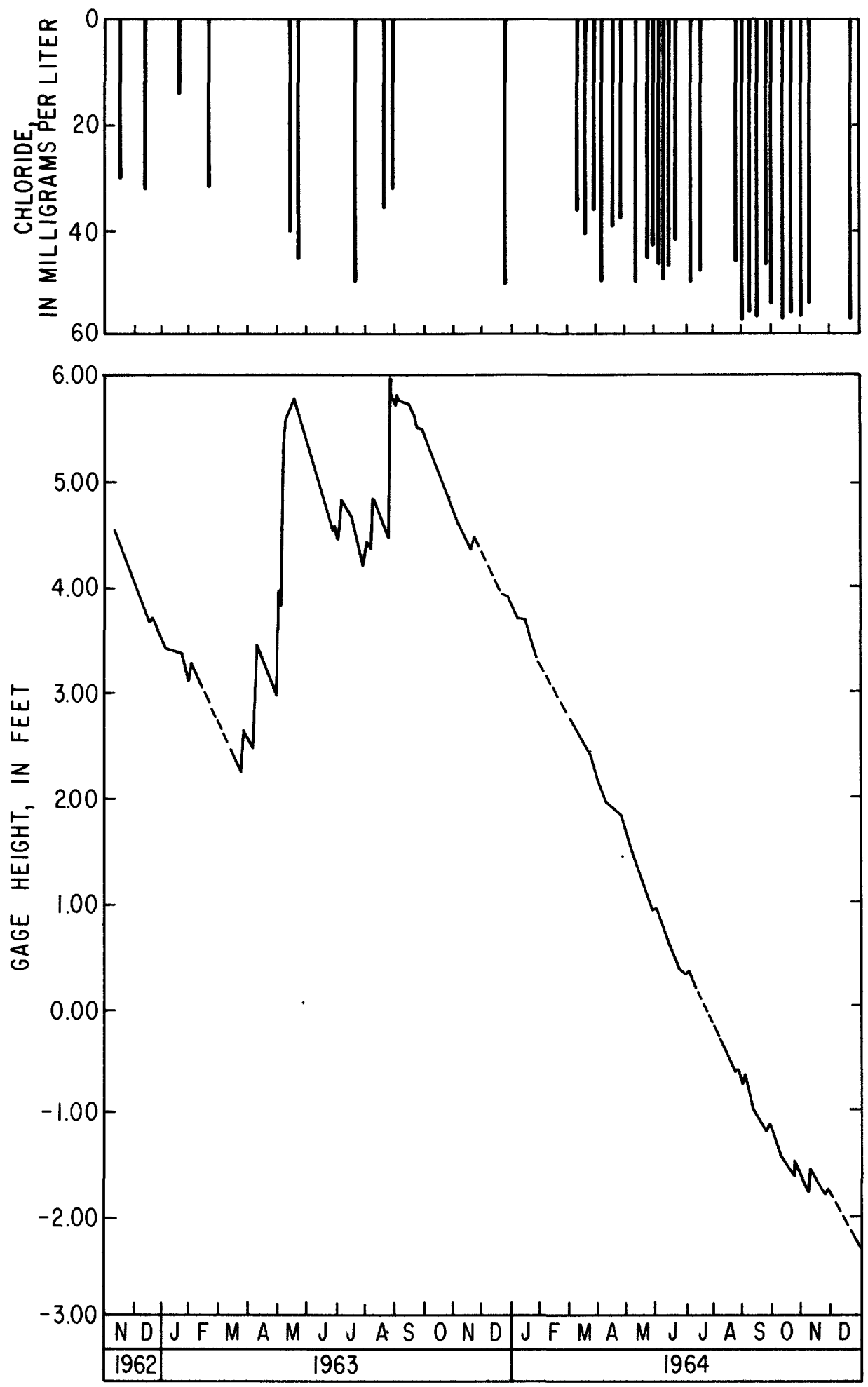

Figure 22.--Stage and chloride content of pond, Estate Hoffman. 
tion of small truck-garden plots. Forty-one ponds having a total capacity estimated to be 90 million gallons have been constructed on St. Thomas. The ponds are maintained by storm runoff, which otherwise would be lost to sea.

The availability of water from the storage ponds is reduced by high evaporation and, in some places, through leakage. A preliminary study to determine total water loss was made during 1963-64 on Hoffman pond in the upper Turpentine Run watershed. Water loss, determined by decline in stage of the pond between major rainstorms and storm inflow, was nearly equal in both years ( 113 inches, 1963, and 107 inches, 1964). The stage of the pond fluctuated from overflow to as much as 8 feet below spillway crest (fig. 22), while the surface area of the pond ranged from 1.6 acres (spillway elevation) to 0.7 acre.

Water loss from the pond is cyclic, similar to pan evaporation, being maximum in summer and minimum in winter ( fig. 23). Losses are attributed to evaporation and leakage. Transpiration can be eliminated as a factor, as no vegetation grows in or on the edge of the pond.

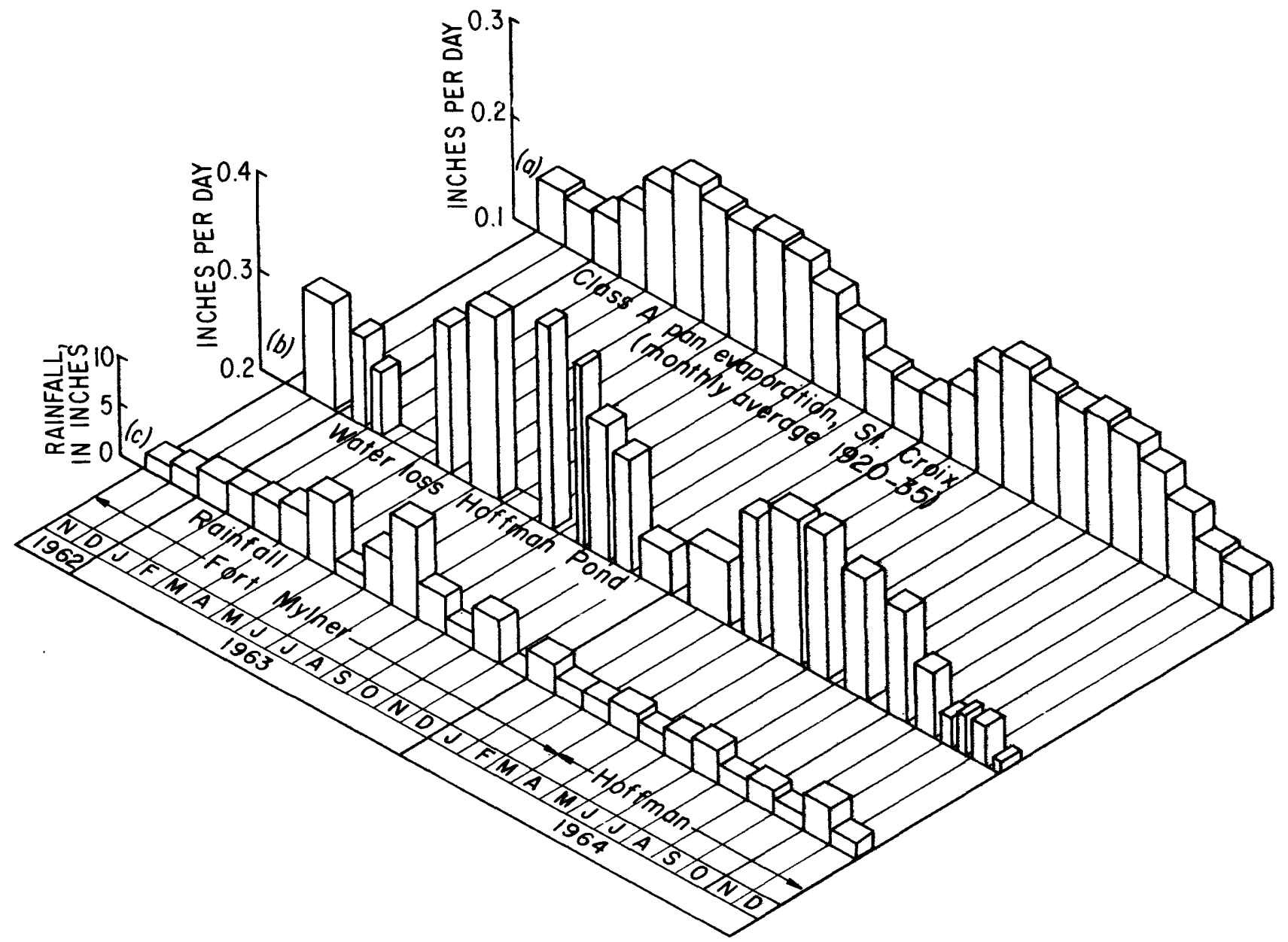

Figure 23.--Water loss from pond, rainfall, and pan evaporation, 
Water loss was greatest when the pond was near crest elevation. Maximum loss averaged 0.40 inch per day, about $11,000 \mathrm{gpd}$ per acre in August 1963, when pond stage averaged 4.8 feet. Minimum loss averaged 0.22 inch per day, about $6,000 \mathrm{gpd}$ per acre, in December 1964, when pond stage averaged -2.0 feet.

Only long-term historical pan evaporation was available to make estimates of evaporation loss. Estimates of evaporation and leakage were made, assuming evaporation loss from the pond was 80 percent of the average monthly pan evaporation and that the residual loss was leakage. The estimates indicate that leakage was greatest at high stages ( 55 percent of water loss in August 1963) and least at low stages ( 45 percent of water loss in December 1964). Leakage ranged from $0.20 \mathrm{gpd}$ per square foot to $0.06 \mathrm{gpd}$ per square foot of wetted ground area. Such rates are considered not to be in excess of the infiltration capacity of the fractured bedrock in which the pond is constructed.

The data emphasize the fact that water loss from a reservoir through evaporation (even one with no apparent leakage) is of sufficient magnitude to minimize the value of prolonged open surface storage.

\section{$\underline{\text { Rainfall Catchments }}$}

A study of the West India Company hillside catchment in eastern Charlotte Amalie showed a recovery of about 70 percent of the total rainfall. The catchment is on a westward-facing slope of about 30 degrees and has a horizontal area of 90,000 square feet.

Recovery, ranging from 0 to more than 200 percent from small showers up to 0.30 of an inch, is attributed to differences in intensity and areal extent of the individual showers over the catchment area. Recovery from rains greater than 0.30 inch had a range from 67 to 80 percent of the total rainfall. However, the statistical mean for both light showers and heavy rains was about 70 percent.

In a year of average rainfall in Charlotte Amalie (long-term average 44 inches), a catchment would yield 19.3 gallons of water per horizontal square foot or an average of 1.6 gallons per month per square foot. For the past 10 years the average annual rainfall has been about 10 percent less than the long-term average. A catchment in this period, 1955-64, would have yielded 17.6 gallons per square foot or an average of 1.45 gallons per month per square foot.

Sufficient storage is always a critical factor with rainfall catchments. As nearly half the annual rainfall normally occurs during the 4-month rainy season, storage must be provided in order to assure a continuous yield during the remainder of the year. Figure 24 shows the accumulated catch (70 percent recovery) of rain on a square foot (horizontal) of the West India Company catchment from 1955 through 1964, based on the rainfall recorded at Charlotte Amalie Harbor Master's office. Storage requirements to retain all the catch would be enormous- -96 percent of the average annual recovery, or 17 gallons of storage for every square foot of catchment. Figure 24 shows the relation of yield of storage. The optimum storage seems to be about 30 percent of annual recovery, or 5.3 gallons of storage per horizontal square foot of catchment; this would produce a yield of 16.3 gallons per square foot annually.

\section{Residential Rainfall Catchments}

Virgin Islands law requires all residential, commercial, and industrial buildings to have a certain minimum cistern storage per square foot of roof area.

Section 308 of Title 29 of the Virgin Is lands Code in pertinent part states as follows :

"1. Cisterns for dwellings, apartments and hotels shall have a minimum usable capacity of 10 gallons for each square foot of roof area for buildings one story and 15 gallons for each square foot of roof area for buildings of two or more stories.

"2. All other buildings shall have cisterns with a minimum useable capacity of $4-1 / 2$ gallons for each square foot of roof area except that churches and warehouses shall not be required to conform to this standard.

"3. Where a building has combined occupancy such as apartment and store; required cistern capacity shall be 10 gallons for each square foot of roof area." 


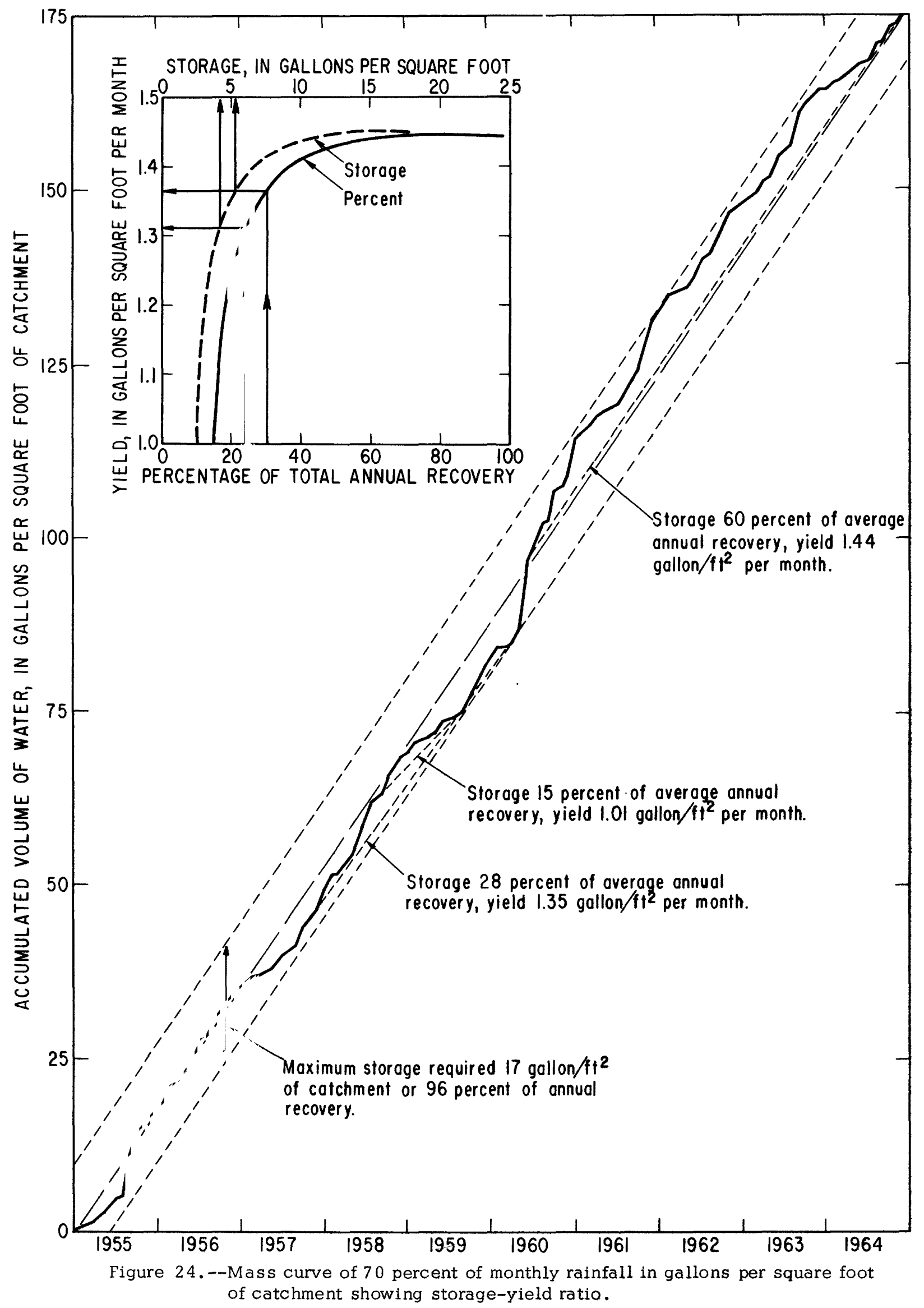


Observations indicate that wind velocity and roof configuration are major factors in the recovery of rainfall from residential structures. High wind will blow rain off a pitched roof oriented parallel to the wind, whereas a rain shadow in proportion to the degree of roof pitch will occur on the lee side of a roof oriented perpendicular to the wind. A V-shaped roof will be affected in the same manner, although probably to a lesser degree. The most efficient is probably a flat roof with a low lip around the edge. Water cannot blow off the roof, nor is a rain shadow created, and the lip converts the roof into a temporary storage container during high-intensity rains. Rainfall recovery on flat roofs is probably greater than that measured from the hillside catchments, whereas recovery on pitch roofs is probably 10 to 20 percent less, depending on orientation and steepness of pitch.

Figure 25 shows an estimate of the annual costs of collecting rainwater and of cistern storage for a small home. Cistern cost, amortized over a 20year period at 5 percent per year (interest costs not included), is estimated to range from $\$ 5.00$ per cubic foot for 10 percent storage to $\$ 2.50$ per cubic foot for 100 percent storage of the total annual recovered rainfall. Rainfall recovery was estimated to be 70 percent of an annual rainfall of 40 inches over 1,000 square feet of roof. Recovery under these conditions would yield $48 \mathrm{gpd}$. It was assumed that water loss due to insufficient storage would be made up by water purchased from water haulers at costs of 10,20, or 30 dollars per 1,000 gallons. The figure shows that, using these criteria, the optimum cistern storage would be about 20 percent of expected annual recovery, or about 3.5 gallons per square foot of catchment. Average yield from rainfall alone would be about $40 \mathrm{gpd}$. Annual water cost would range from $\$ 130$ to $\$ 196$ annually, or $\$ 7.45$ per 1,000 gallons to $\$ 11.20$ per 1,000 gallons. Annual cost of 100 percent cistern storage would be $\$ 294$ or $\$ 16.80$ per 1,000 gallons.

\section{Ground Water}

Ground water is available in nearly all parts of the island in sufficient quantity to be of importance to the water supply. In general, yields of wells are sufficient only for individual domestic supplies. There are, however, a few areas where yields to wells are large enough to warrant

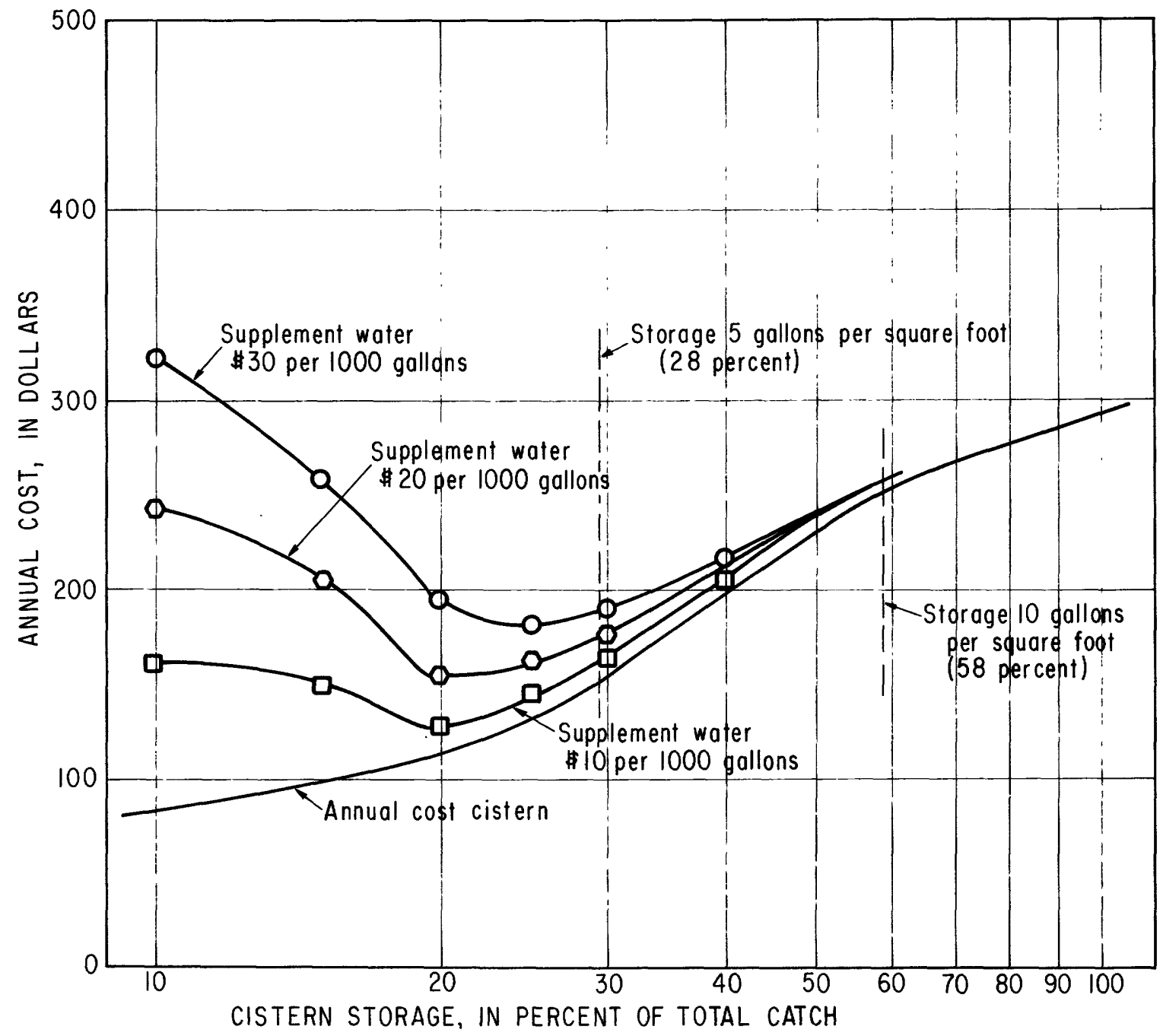

Figure 25.--Annual cost of water from a roof catchment of 1,000 square feet with a maximum yield of 48 gallons per day. 
Table 4.--Scale of values for determining ground-water potential from physical criteria and examples for selected wells

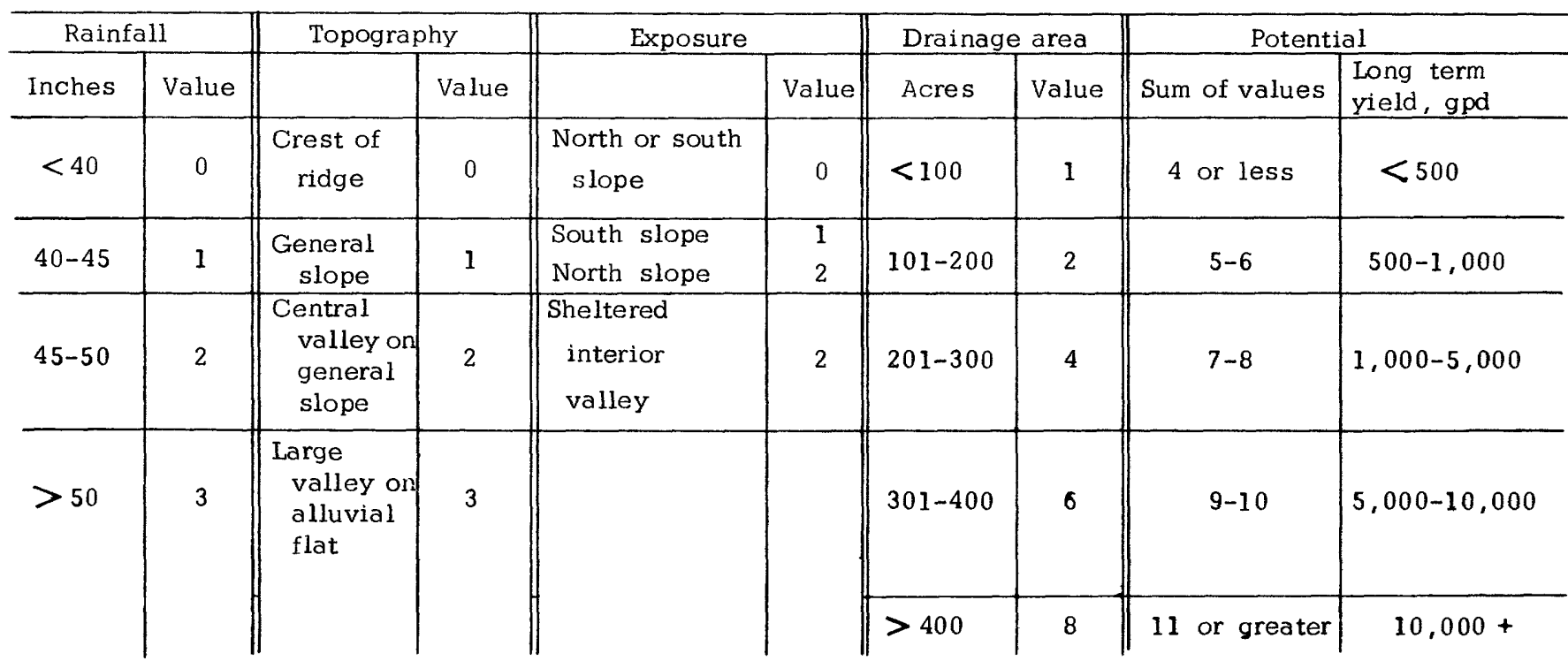

Examples

\begin{tabular}{|c|c|c|c|c|c|c|}
\hline Well 3 & 2 & 2 & 2 & 1 & 7 & $1,000-5,000$ \\
\hline Well 10 & 1 & 1 & 1 & 1 & 4 & 500 \\
\hline Well 22 & 1 & 2 & 2 & 2 & 7 & $1,000-5,000$ \\
\hline Well 20 & 1 & 3 & 2 & 6 & 12 & 10,000 \\
\hline Well 16 & 1 & 4 & 2 & 6 & 13 & 10,000 \\
\hline
\end{tabular}


the development of public supplies for local use. The water, as a whole, is of poor quality, being slightly mineralized, but can still be considered potable. It can be blended with cistern water, yielding a mixed water of more acceptable potability. Householders who have wells generally prefer a dual system, using the well water for washing, lawn watering, and sanitary purposes and rain water for drinking and cooking.

\section{Ground-Wateı Potential}

The ground-water potential of an area can in large part be determined by the averare annual rainfall, topography, and exposure to solar radiation. In general, areas receiving less than 40 inches of rainfall have a low ground-water potential. The southern slopes of the island, where, because of solar radiation, evapotranspiration is high and recharge is low, generally have less ground-water potential and yield more highly mineralized water than the north slopes. Topography is important in that on the flatter slopes groundwater recharge is favored.

A crude scale based on rainfall, topography, exposure, and drainage-basin area was developed for estimating ground-water potential of the rocks of the island (table 4). The different features are assigned values ranging from 0 to 8 . The sum of these values is a number from which an estimate of the long-term yield of a well can be obtained. A deep well will generally yield more water than a shallow well in the same location. For the purpose of the scale, a well depth of about 200 feet is assumed with the water level in the well at 50 feet below land surface. Little water is yielded from depths of more than 200 feet below the water table.

It is emphasized that even though conditions appear favorable for obtaining a ground-water supply, there is always a possibility no water will be obtained as a well may not penetrate waterbearing strata.

\section{Water in Consolidated Rocks}

The permeable zones of the consolidated rocks consist of open joints and fractures. Near the land surface the joints are open--the result of weathering and release of pressure. Joint openings, however, narrow rapidly with depth, and generally at depths of a few hundred feet they are too narrow to transmit significant quantities of water.

All the bedrock formations are broken by faults-fractures along which movement has taken place. In some faults, earth movement has crushed the rock to gravel-size breccia, whereas in others the rock has been reduced to a flourlike substance called fault gouge. Brecciated fault zones not sealed by mineral deposits or fault gouge can be very permeable and often extend to depths of hundreds of feet.

The orientation of many of the valleys and bays evidently is controlled by a fault and joint system along which erosion has occurred. Valleys, therefore, are often indicators of zones of an extensive jointing or fracturing system that may contain ground water.

The yield to wells drilled in the bedrock is small--generally less than 1,000 gpd. Many wells will yield 5 to $10 \mathrm{gpm}$ (gallons per minute) for about 10 hours. After that they yield at a much reduced rate as a result of removal of water from storage in the immediate vicinity of the well. Once water in local storage is removed, the yield to the well is reduced to the general yield of the aquifer. For example, well 17 near Wintberg reportedly yielded $12 \mathrm{gpm}(17,000 \mathrm{gpd}$ ) for a 24hour pumping period when first drilled. However, almost daily use over the past 5 years has shown that the long-term yield of the well is about 250 gallons per day.

The consolidated rocks are permeable as a result of interconnected open fractures along joints and faults, which tend to be linear. However, permeability may vary significantly along a lineation.

One example of possible linear permeability is the north-south fault in eastern Charlotte Amalie. Permeability, as determined from pumping tests of wells, ranged from about 1 to $9 \mathrm{gpd}$ per $\mathrm{ft}^{2}$ (gallons per day per square foot) east and west of the fault. Immediately along the fault zone in the vicinity of the race track, however, permeability ranged from about 70 to $150 \mathrm{gpd}$ per $\mathrm{ft}^{2}$. Southward along the fault permeability was $1 \mathrm{gpd}$ per $\mathrm{ft}^{2}$. 
The effective porosity, or storage capacity, of the consolidated rock also is related to open interconnected fractures and joints. Effective porosity in the upper Turpentine Run basin is estimated to be 4 percent based upon changes in the groundwater level in response to rainfall. Effective porosity of the rocks in most of the island is estimated to be 1 percent or less.

\section{Water in Unconsolidated Rock}

Water-bearing unconsolidated deposits are present only in Turpentine Run Valley and in coastal embayments. These deposits consist of two different lithologic types, which have a variety of water-bearing characteristics. They can be divided into (1) a bouldery silt and clay alluvium, which contains lenses and beds of sand and gravel, and (2) beach deposits, predominantly coral sand and occasional interbedded zones of coral, beach rock, and organic silt and clay. In the coastal embayments, alluvial and beach deposits may interfinger.

The alluvial deposits are predominantly fine grained, and, although they have a high porosity, they have a low permeability and will yield water only slowly to wells. Water in these deposits is with few exceptions under water-table conditions. Sand and gravel beds and lenses in the alluvium are rare. Where present, however, they will yield water readily and act as a large collector system into which water from the less permeable alluvium will percolate. Occasionally the water in the sand and gravel beds is under artesian pressure because they are confined by the less permeable overlying alluvium.

The beach deposits, principally medium to coarse coral sand, have a moderate to high permeability and porosity and will yield water readily to wells. The moderate to high permeability of the beach deposits is often detrimental in that saltwater encroachment can easlly occur.

\section{Water Table}

Ground water in St. Thomas is a ssumed to be under water-table conditions--that is, the water surface is unconfined, open to the atmosphere, and free to rise and fall. Sufficient data are not available to show contours of the surface of the water table throughout the island. In general, the water table roughly parallels the topography. The depth to the water table is a few feet below land surface in the coastal embayments but may be as much as 120 feet below land surface near the crest of the central ridge.

The water table responds to changes in the quantity of water stored in the ground-water reservoirs. The water table rises when recharge from rainfall or streamflow exceeds the discharge; it declines when discharge to springs, streams, or the sea, evapotranspiration from the water table, and withdrawal of water from wells exceed recharge.

\section{Water-table fluctuations}

The hydrograph of well 1 in figure 26 is typical of the water-level fluctuations in the rock aquifer of the south coast. Recharge follows the infrequent heavy rainstorm or smaller storms in a wet period. The overall low storage capacity of the rock causes a rapid rise in water levels, but the steep hydraulic gradients result in rapid losses and almost as rapid declines.

Figure 27 is the hydrograph of well 24 tapping the alluvium and weathered bedrock in the lower Turpentine Run Valley, and figure 28 is the hydrograph of well 21 in the alluvium of the upper basin. Recharge is received every time storm water runs off in the stream and water levels rise. Between times of storm runoff, ground-water levels are partly maintained by the infiltration of base flow from the stream when flow is present.

The hydrograph of well 19 in figure 29 shows the pattern of water-level fluctuations of the rock aquifer in upper Turpentine Run basin. The pattern is similar to that of the rock aquifer of the north coast and larger valleys on the south coast. Here, greater permeability and storage capactty and generally thicker soil and alluvium result in a slower but more prolonged response to recharge and a slower discharge. The "troughs" in the hydrograph during early 1965 were caused by pumpage (averaging $18,000 \mathrm{gpd}$ ) from a nearby well.

\section{Recharge}

The bedrock aquifer is principally recharged by infiltration of rain on the land surface. Streamflow and storm runoff locally recharge the alluvium, which may, in turn, contribute water to the bedrock aquifer in the major valleys and alluviated coastal embayments. 


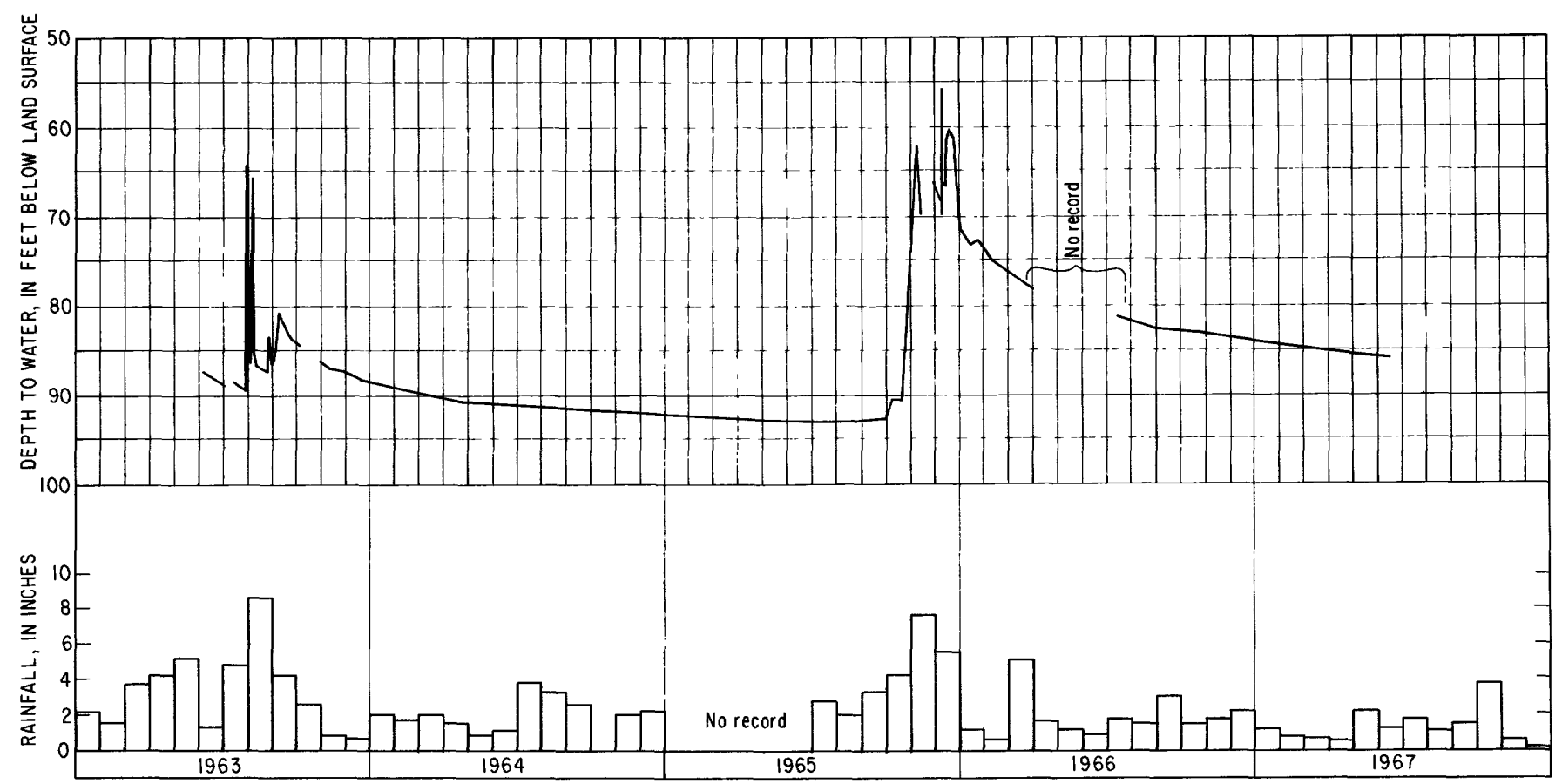

Figure 26.--Hydrograph of well 1 drilled in bedrock at Estate Fortuna. Rainfall at Harry S. Truman Airport. National Weather Service gage.

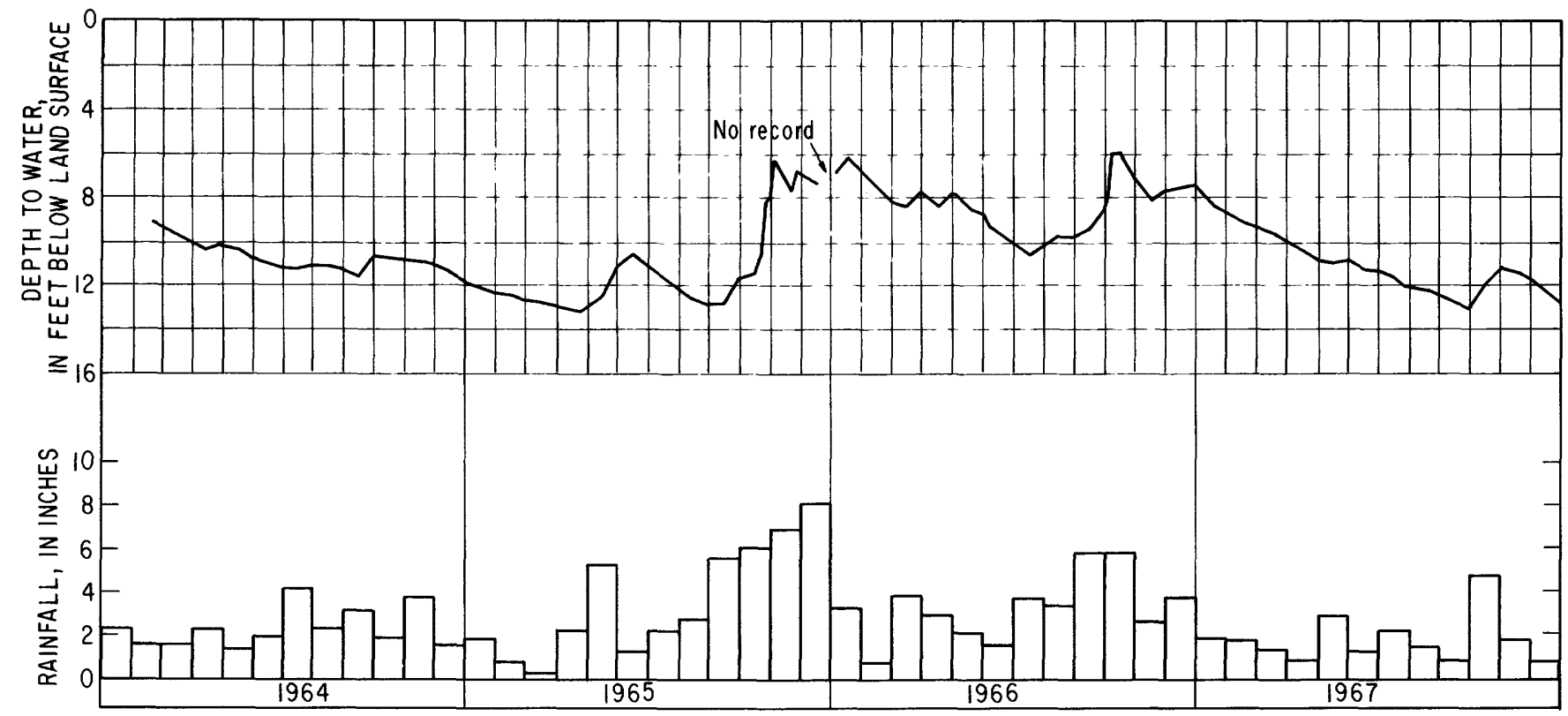

Figure 27.--Hydrograph of well 24 drilled in alluvium and bedrock in valley of Turpentine Run, Estate Mariendal. Rainfall Estate Fort Mylner. National Weather Service gage. 


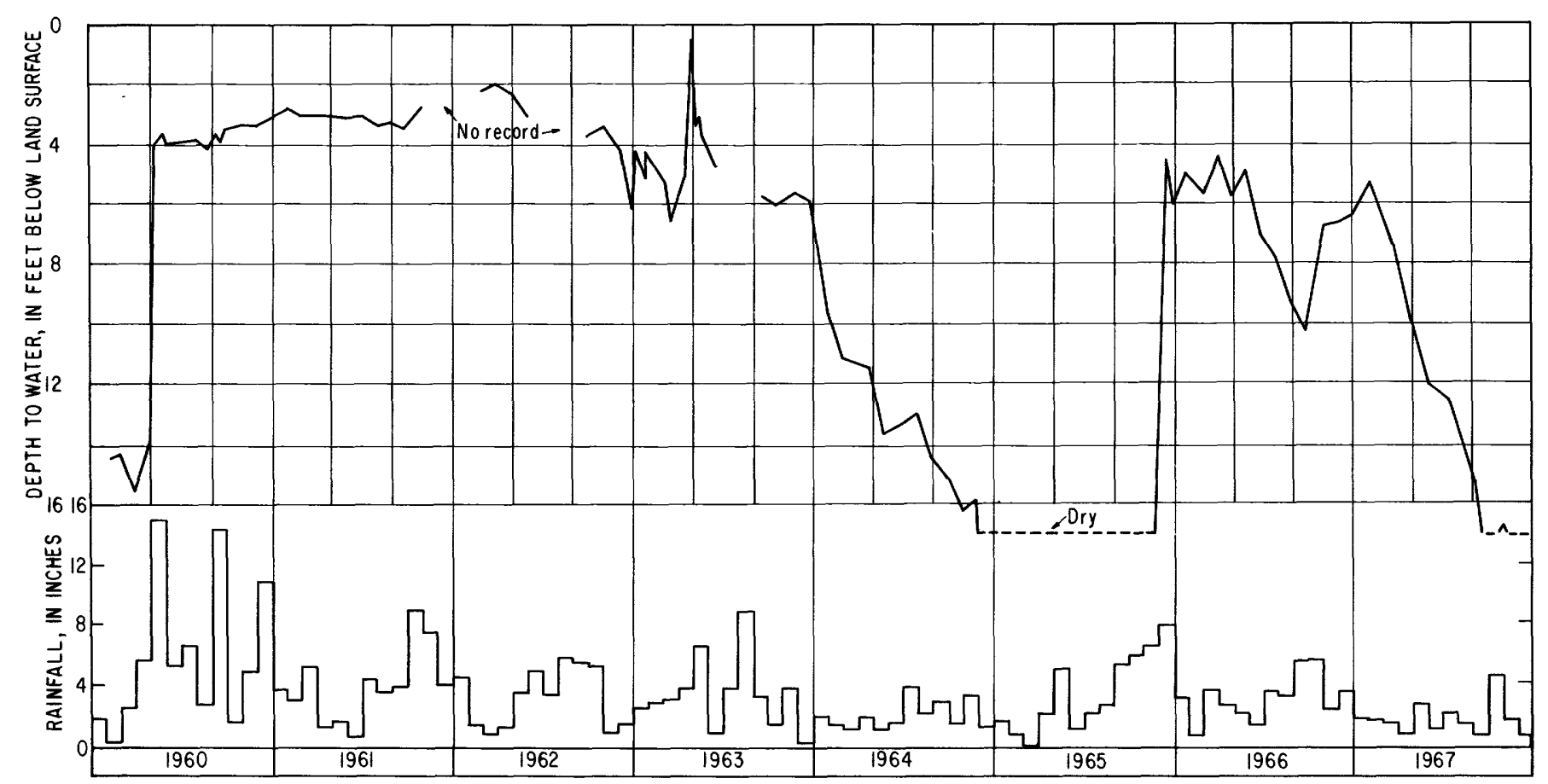

Figure 28.--Hydrograph of well 21 dug in alluvium of Turpentine Run at Estate Fort Mylner (Mt. Zion) . Rainfall at Estate Fort Mylner (Mt. Zion). National Weather Service gage.

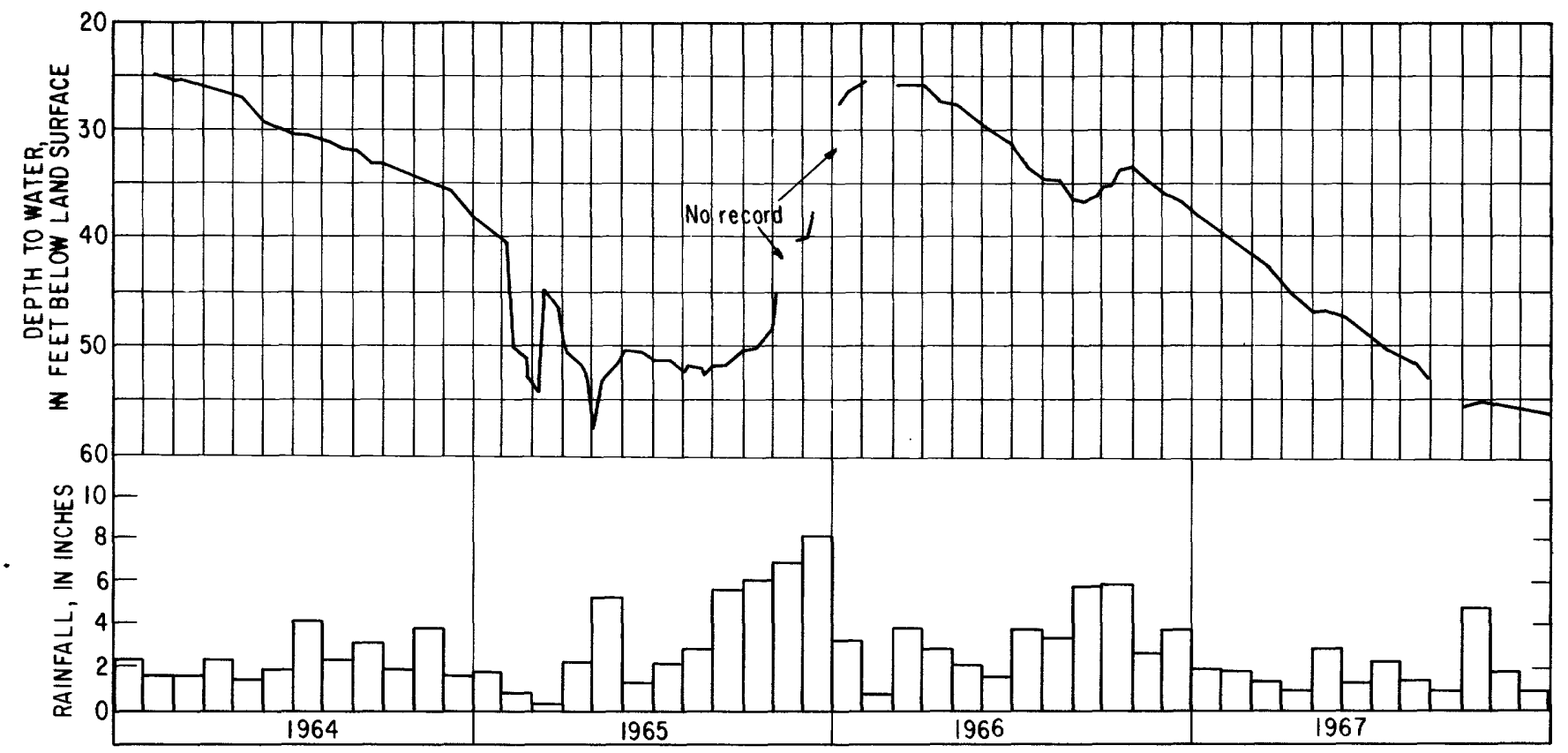

Figure 29.--Hydrograph of well 19 drilled in bedrock at Estate Tutu. Rainfall at Estate Fort Mylner (Mt. Zion). National Weather Service gage. 
Rainfall, vegetation, evaporation, surficial deposits, and exposure to solar radiation are the main factors affecting recharge to the aquifers.

Leaky-salt water and sewage mains in Charlotte Amalie and effluent from sewage plants in the Turpentine Run basin also contribute water to the aquifers as does effluent from septic tanks throughout the island. Recharge from these sources is detrimental as it is a potential source of pollution.

The bedrock aquifer is recharged infrequently and only after a heavy rain or series of lesser rains. The amount depends on the antecedent rainfall and the degree to which soil moisture has been depleted by evapotranspiration since the last rain. Extensive brush cover and the granular nature of the soil cause rapid evapotranspiration. Conversely, the granular nature of the soil will allow water to pass through the soil zone without the soil being completely saturated--saturation being required only along the conduits between the soil granules. This reduces the water needed to satisfy soil-moisture requirements before recharge can take place. Even then, under dry conditions, a major rainstorm of 2 inches or more, or the equivalent in lesser rains, is necessary to initiate recharge to the bedrock aquifer. The amount of rainfall necessary for recharge varies from one part of the island to another. On the north slope 1 inch of rain may cause recharge, whereas on the south slope, under dry conditions, 3 inches or more may be necessary for recharge.

The fluctuation of ground-water levels indicates that recharge to the aquifers on the south-facing slopes is less frequent than on the north-facing slopes. Less frequent recharge on the south slopes is attributed to the greater solar radiation received by these slopes, which results in increased evapotranspiration and a greater soil-moisture deficiency. Consequently, a greater volume of water is necessary to overcome the soil-moisture deficiency before recharge takes place.

Where the surficial deposits (saprolite or alluvium) are thick, ranging from 2 to 15 feet, as on the north slope in the vicinity of Dorothea, in upper Turpentine Run basin, and in the alluvial embayments, such as at Long Bay and the Harry S. Truman Airport, water is retained in the surficial deposits and takes a much longer time to reach the bedrock aquifer. Peak recharge to the bedrock aquifer may lag as much as a month behind the rainfall. In some places little recharge reaches the bedrock aquifer--as most is discharged to springs or streams directly from the saprolite or alluvium, as has been observed in the vicinity of Dorothea on the north slope.

Runoff from major rainstorms is the principal recharge to the aquifers of the coastal embayments and is an important source of recharge to the alluvium of Turpentine Run. Base flow of Turpentine Run and Bonne Resolution Gut at Dorothea Bay, when present, also contributes recharge to the unconsolidated aquifers in their respective basins.

For convenience of discussion, the island has been divided into five ground-water areas as shown in figure 30. Estimates of yield in these areas are given in table 5 .

Table 5.--Estimated yield of ground-water areas. (See fig. 30)

\begin{tabular}{|c|c|c|c|c|}
\hline \multirow{2}{*}{$\begin{array}{c}\text { Ground-water } \\
\text { area }\end{array}$} & \multirow{2}{*}{$\begin{array}{l}\text { Area, } \\
\text { sq mi }\end{array}$} & \multicolumn{2}{|c|}{ Estimated yield } & \multirow{2}{*}{$\begin{array}{c}\text { Annual recharge, } \\
\text { inches }\end{array}$} \\
\hline & & gpd & $\mathrm{mg} / \mathrm{yr}$ & \\
\hline 1 & 13.6 & 450,000 & 164 & 0.7 \\
\hline 1. (Long Bay) & .31 & 70,0003 & 25 & 4.9 \\
\hline 1 (Lindberg Bay) & $.2 \vec{I}$ & $30,000 \underline{3}$ & 11 & 4.3 \\
\hline 2 & 3.4 & 350,000 & 128 & 2.2 \\
\hline 2 Upper basin & 2.3 & 300,0004 & 110 & 2.8 \\
\hline 2 Lower bas in & 1.1 & $50,000 \underline{4}$ & 18 & 1.1 \\
\hline 3 & 4.6 & 250,000 & 91 & 1.2 \\
\hline 4 & $.42 /$ & 100,000 & 36 & 5.3 \\
\hline 5 & 10.0 & 100,000 & 36 & .2 \\
\hline Total & 32 & $1,250,000$ & 455 & \\
\hline
\end{tabular}

1. Approximate area of alluvium only.

2/ Does not include drainage basins at Areas 1 and 5 which contribute recharge to Area 4 from surfacewater runoff.

3/ Yield included in Area 1 total.

4/ Yield included in Area 2 total.

Ground-Water Areas

Area 1

Area 1 encompasses about half the land area. It is underlain principally by fractured volcanic tuff and breccia of the Louisenhoj Formation, on which 1 or 2 feet of soil have developed. On the south side of the island, from the vicinity of Charlotte Amalie westward to Brewers Bay, the volcanic rock has been extensively fractured. The fractures, however, have been filled with 


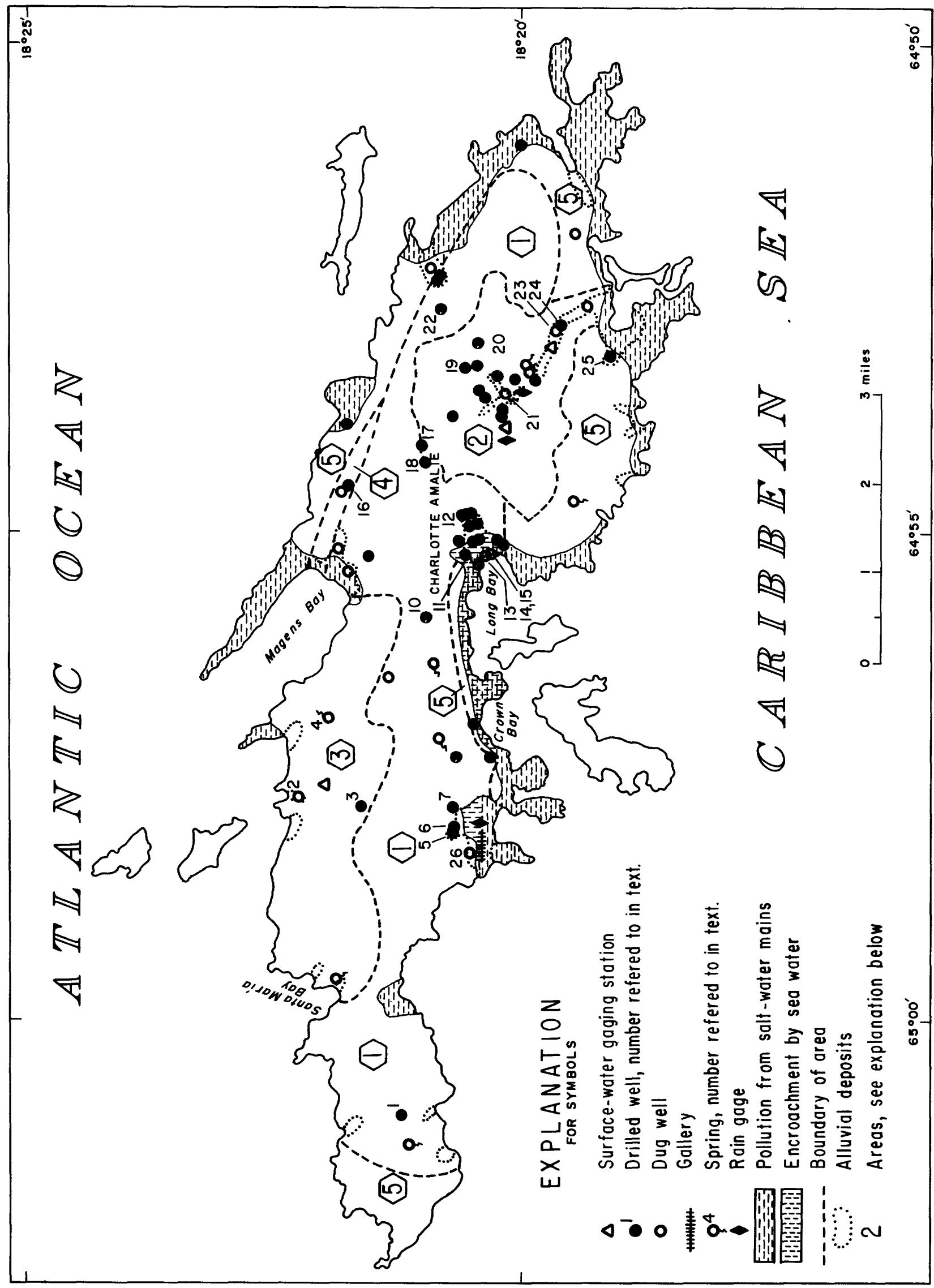




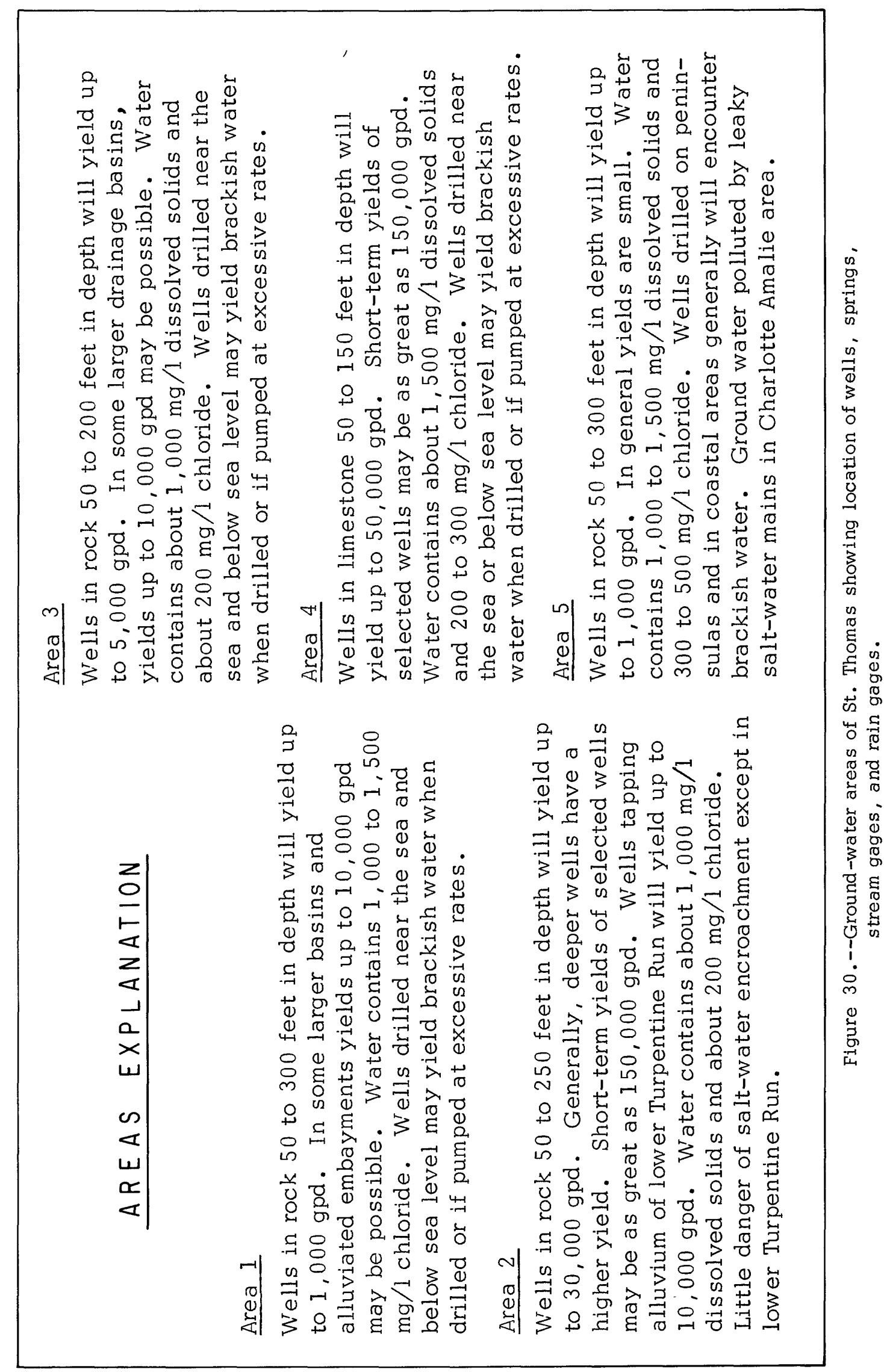


secondary minerals.

Alluvium and beach deposits fill the coastal embayments and are especially prominent in the Charlotte Amalie area .

Ground-water levels range from a few feet below land surface in the embayments near the sea to as much as 120 feet below land surface on the central ridge. Depth to the water table is greatest beneath ridges and least in the valleys and lowlands.

Wells range in depth from 50 feet in the low coastal areas to 250 feet or more near the central ridge. In general, the higher the altitude of the well site the greater the depth of the well. There is really no particular depth at which an aquifer can be successfully tapped, as yield depends entirely on the depth and density of open water-bearing fractures. A well in the Long Bay area (well 12) at an altitude of 40 feet was drilled to a depth of 120 feet before water-bearing fractures were penetrated. Well 10, on the other hand, at an altitude of 320 feet on the slope of the central ridge, penetrated water-bearing fractures at 60 feet. These, of course, are extremes. Long-term yields of wells generally range from 250 to $1,000 \mathrm{gpd}$, although initial or short-term yields may be 10 times greater.

Two valley areas, Long Bay and Lindberg Bay on the east and west edge of Charlotte Amalie, respectively, have greater ground-water potential than the remainder of Area 1 .

Long Bay. - The Long Bay area lies in a basin about 1 square mile in extent, of which about 0.3 square mile is alluviated coastal embayment, and the remainder is steep-sloped volcanic ridges with little soil cover. Alluvium as thick as 60 feet overlies the bedrock. Near the coast the alluvium underlies and interfingers with a thin beach-sand deposit. A relatively impervious clay overlies the bedrock from a line about 1,500 feet inland seaward to the shoreline at Long Bay, and probably extends out under Long Bay. Water is present in the alluvial deposits, but the main aquifer is the underlying volcanic rock. In general, the bedrock underlying the alluvium yields more water than that underlying the ridges. The zone of greatest yield to wells is bound by the two faults passing through the area.

A factor contributing to the productivity of the bedrock is the overlying alluvium that acts as a storage reservoir. The alluvium contains large quantities of water. Because of its low permeability it generally yields little water to wells, but it yields water slowly to the underlying bedrock aquifer. The principal area of recharge to the bedrock aquifer from the alluvium is the foot of the volcanic ridges inland of the edge of the impervious clay wedge capping the bedrock and mostly upgradient from the area of leaky saltwater mains.

The long-term yield of the alluvium-bedrock aquifer is estimated to be from 60,000 to 80,000 $\mathrm{gpd}$. The yield of wells ranges from about 500 to $70,000 \mathrm{gpd}$. The high yield of some of the wells, however, has little to do with the longterm yield of the aquifer. Sustained pumpage in excess of the long-term yield of the aquifer will deplete the fresh ground water in storage and probably result in salt-water encroachment.

Salt water has encroached in a narrow strip of the alluvial aquifer bordering Long Bay because of pumping dug wells 13, 14, and 15, which supply Pearson Gardens public housing. Nearly half the alluvial aquifer, however, is contaminated to some degree by leaky salt-water mains. The approximate limits of salt-water contamination are shown in figure 30 . The bedrock aquifer underlying most of the contaminated alluvium contains fresh water because the principal recharge area is upgradient of the relatively impermeable clay cap overlying the bedrock throughout most of the contaminated areas.

Salt water has entered the bedrock in at least one place. Well 11 became salty after being pumped heavily for about 3 months. Salt water from the alluvium has apparently entered the bedrock aquifer through several improperly constructed wells. In each the annular space between the wall of the well and the casing was left open, and salt water moved down the annular space, contaminating the bedrock aquifer in the vicinity of the well. 
Lindberg Bay. --The alluvial basin behind Lindberg Bay is very similar to that of Long Bay except that there is no impervious clay cap overlying the bedrock. Total basin area is nearly 1.5 square miles, most of which is steep-sloped volcanic ridges. Alluvium as thick as 40 feet extends from the foot of the ridge and slopes seaward, where it interfingers with beach sand. The alluvium covering about 0.2 square mile is not as extensive as it would appear, as much of the area of the airport is filled land. Pumping tests of the dug wells in the alluvium show that it has a very low permeability. However, the porosity of the alluvium is probably about 30 percent.

The underlying bedrock is volcanic breccia and tuff, much of it altered by heat from intrusions. Locally, fracturing is extensive, but many of the fractures are filled with secondary minerals.

Three wells, 5, 6, and 7, have been drilled in the bedrock along the upper edge of the alluvial deposits. Well 7 was dry, although it was drilled to a depth of 200 feet. Wells 5 and 6 have a longterm yield, estimated to be $3,000 \mathrm{gpd}$. Bedrock wells probably will yield 10,000 gpd in the central part of the embayment north of the airport. The alluvium is relatively thick there and, thus, it should contribute considerable quantities of water to the underlying bedrock aquifer.

The potential yield of the bedrock aquifer is estimated to be $30,000 \mathrm{gpd}$, as suming data obtained from the Long Bay area can be applied.

Salt-water mains in the Bourne Field housing area are known to leak, and it must be assumed that the alluvium in that vicinity is contaminated. The same care to prevent salt-water contamination by improper well construction must be taken here as in the Long Bay area.

At one time a gallery paralleling the runway at the airport was used for water supply. This gallery, which collected runoff from the runway and stored water in the alluvium and landfill for future use, had a yield estimated to be $13,000 \mathrm{gpd}$. Unfortunately, the gallery was overpumped and salt-water encroachment followed. Salt water is still present in the alluvium near the well and is in a position to intrude the bedrock aquifer.

Water from the gallery occasionally is used for nonpotable purposes. The use of water from runway drainage for drinking purposes, of course, is dangerous because of the presence of toxic compounds such as hydrocarbons and tetraethyl lead from spilled aircraft fuels.

\section{Area 2}

Area 2 is the drainage basin of Turpentine Run. For convenience it is separated into an upper and lower basin; the upper basin above the streamgaging station near Mt. Zion, and the lower basin below it. The principal rocks are volcanic flows, tuff, and breccia. Alluvium as thick as 40 feet lies in the main stream channel of the lower basin. A northwest-oriented fractured and jointed zone of hydrothermally altered rock bisects the upper basin.

Drilled wells range from 40 to 250 feet in depth. The shallower wells tap the alluvium and weathered bedrock of lower Turpentine Run. The depth of the rock wells is not necessarily a criterion of greater yield, but is usually an indication of where a zone of water-bearing fractures was penetrated. Short-term yields from individual rock wells in the upper basin are as great as $150,000 \mathrm{gpd}$. Sustained yields, however, range from about 3,000 to $30,000 \mathrm{gpd}$. Individual wells in lower Turpentine Run yield as much as $30,000 \mathrm{gpd}$, but sustained ground-water withdrawals of more than 10,000 gpd will probably result in sea-water encroachment.

Ground-water levels.--Contours of the groundwater surface during August 1965 and January 1966, are shown in figures 31 and 32 . The arrows on these maps indicate the general direction of ground-water movement. In the upper basin, when water levels are high, ground-water flow is split--part moving along the course of Turpentine Run and part moving through the fractured and altered zone at Mt. Zion and emerging as a series of springs discharging to Turpentine Run in the lower basin. When ground-water levels are low in the upper basin, nearly all ground water is probably discharged through the fractured zone at $\mathrm{Mt}$. Zion, and a temporary ground-water divide is established at the position shown in figure 31 .

Ground-water levels in the basin fluctuate in relation to discharge from and recharge to the aquifers. Figures 29 and 27 are the hydrographs of wells 19 and 24 drilled in bedrock in the upper basin and in the alluvium and weathered rock of 


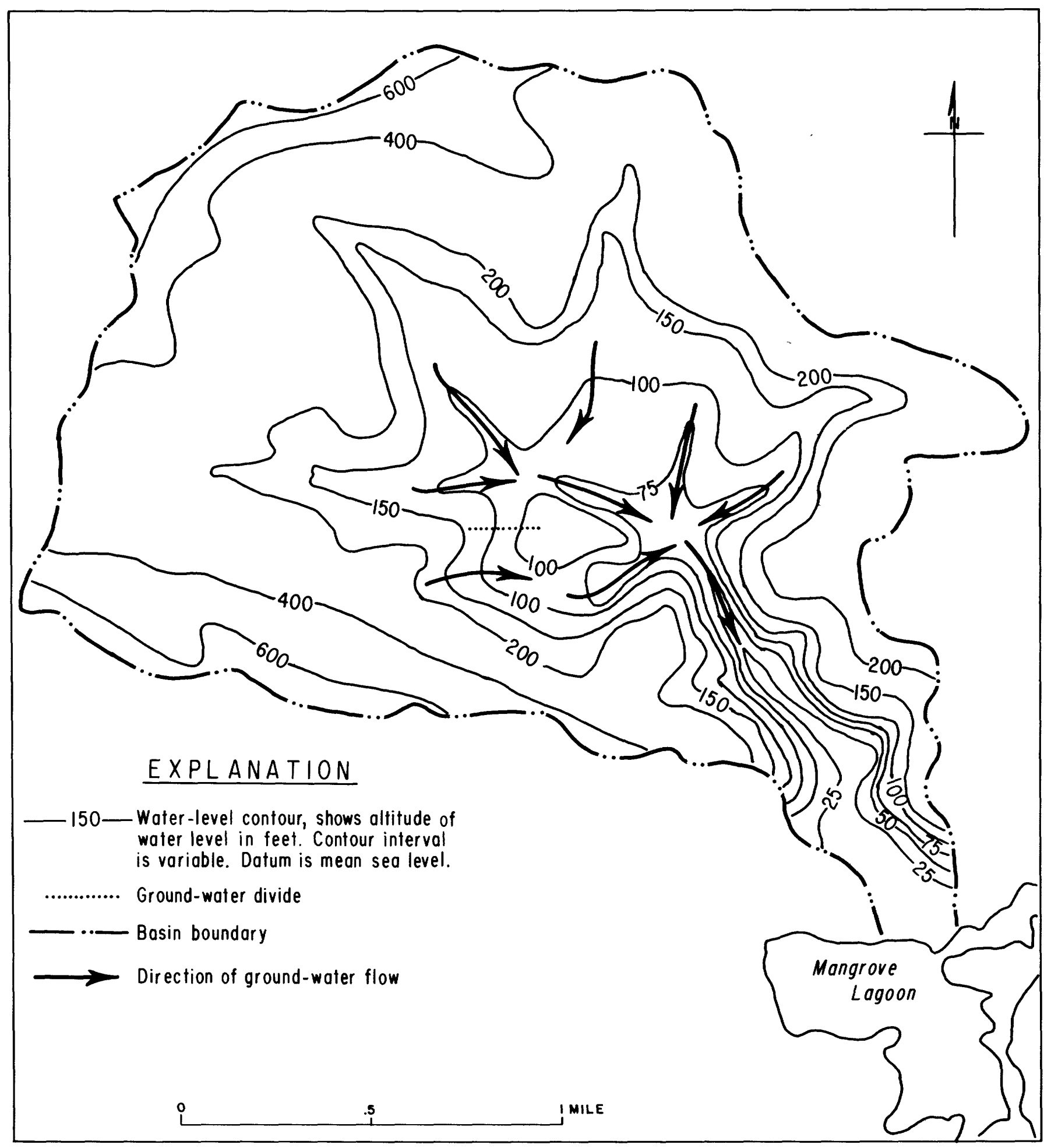

Figure 31.--Contours of ground-water surface in Turpentine Run basin, August 1965. Arrows show direction of flow. 


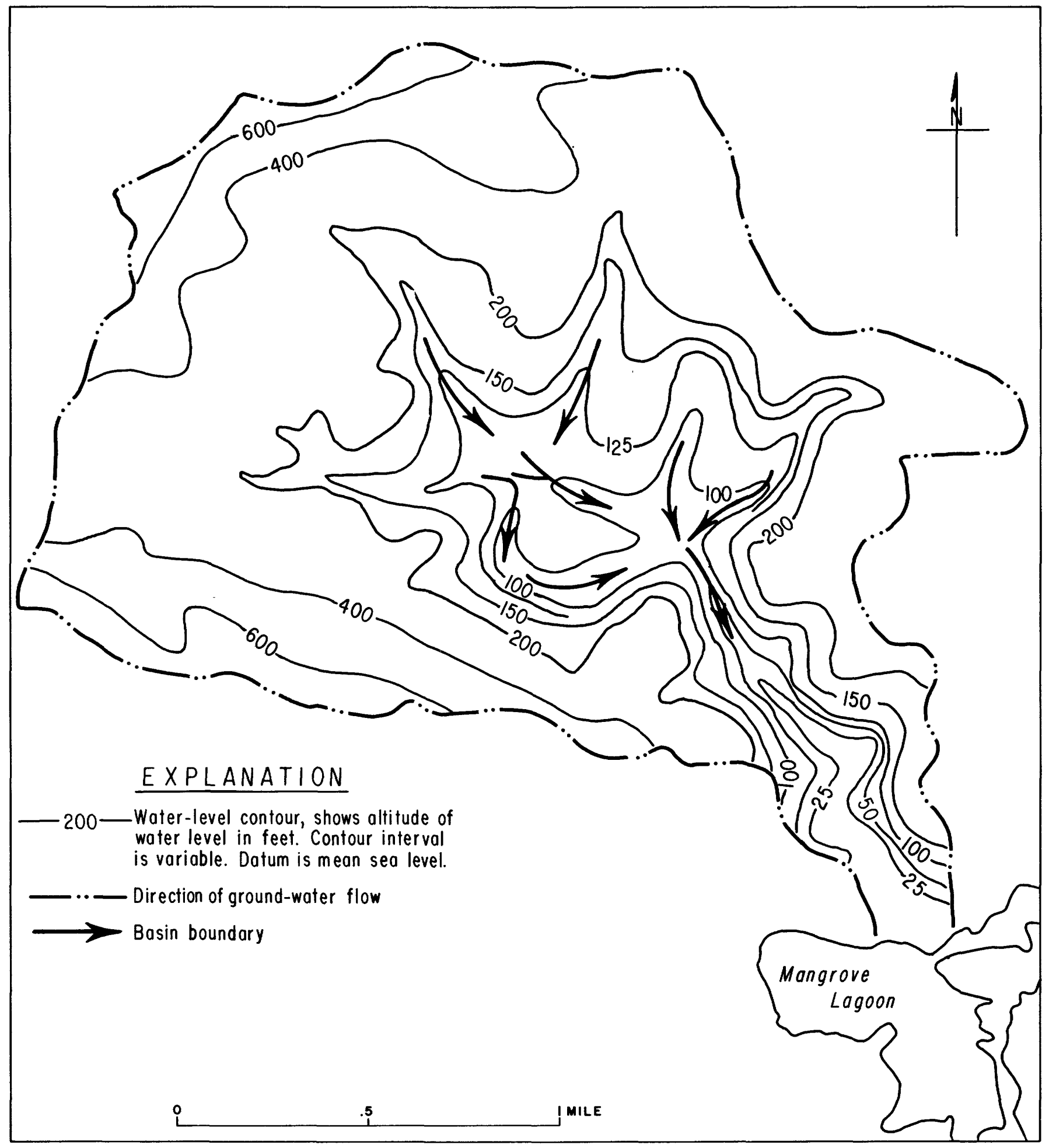

Figure 32.--Contours of ground-water surface in Turpentine Run basin, January 1966. Arrows show direction of flow. 
the lower basin, respectively. The hydrographs of the wells are similar, except that the hydrograph for well 24 shows the effect of recharge to the alluvium by storm runoff from rainstorms sufficient to cause runoff by exceeding the infiltration capacity of the soil, but not sufficient in volume to satisfy soil-moisture requirements and subsequently recharge the bedrock aquifer tapped by well 19.

Recharge to bedrock.--The principal bedrock aquifer is recharged from the occasional major rainstorm. Estimates of recharge from data obtained from the upper basin are probably applicable to most of Area 2 .

Correlation of rainfall, runoff, and ground-water levels show that recharge is in part dependant upon antecedent rainfall and soil-moisture conditions. Generally at least 2 inches of rainfall in a 48-hour period is necessary for recharge. Apparently, 2 inches of rainfall is necessary to satisfy evaporation and soll-moisture requirements, and when rainfall is in excess of 2 inches the bedrock aquifer will be recharged. Annual recharge was computed on this basis, using rainfall at Estate Fort Mylner for the years 1958 through 1967. A summary is given in table 6 .

Table 6.--Estimated annual recharge to bedrock aquifer of upper Turpentine Run basin

\begin{tabular}{l|c|r|r|r|r}
\hline Year & $\begin{array}{c}\text { Rainfall, } \\
\text { inches }\end{array}$ & $\begin{array}{c}\text { Recharge- } \\
\text { causing } \\
\text { rainstorms }\end{array}$ & $\begin{array}{c}\text { mg over } \\
\text { basin }\end{array}$ & $\mathrm{mg} / \mathrm{sq}$ mi & inches \\
\hline 1958 & 47.02 & 4 & 190 & 83 & 4.8 \\
1959 & 29.68 & 0 & 0 & 0 & 0 \\
1960 & 71.34 & 9 & 634 & 275 & 15.8 \\
1961 & 48.46 & 6 & 159 & 69 & 4.0 \\
1962 & 41.10 & 3 & 88 & 38 & 2.2 \\
1963 & 43.75 & 6 & 208 & 90 & 5.2 \\
1964 & 28.05 & 0 & 0 & 0 & 0 \\
1965 & 42.30 & 4 & 124 & 54 & 3.1 \\
1966 & 39.88 & 2 & 43 & 19 & 1.1 \\
1967 & 22.91 & 1 & 36 & 16 & .9
\end{tabular}

Recharge to the bedrock aquifer is dependent not only on the frequency but also the volume of major rainstorms. In 1963, for example, recharge and rainstorms were twice that of 1962 , but the major difference was due to a 5 -inch rain in 1963 . Based on the frequency of occurrence of 48-hour rainstorms at Estate Fort Mylner, figure 33, an annual recharge of about 105 million gallons ( 46 $\mathrm{mg} / \mathrm{sq} \mathrm{mi}$ ) is obtained, with an additional 55 million gallons ( $24 \mathrm{mg} / \mathrm{sq} \mathrm{mi}$ ) or more being recharged about every other year.

Recharge to alluvium.--The principal alluvial aquifer is in the lower reaches of Turpentine Run. The alluvium is recharged by base flow and storm runoff from upper Turpentine Run and by direct ground-water discharge from the upper basin.

The infiltration capacity of the alluvium in the lower reach of the stream is demonstrated by the fact that the 1,500-foot alluviated reach upstream from the Mariendal gage has, on occasions, infiltrated as much as $100,000 \mathrm{gpd}$ of storm runoff. Infiltration into the alluvium between the Mariendal gage and the sea is estimated to be as much as $750,000 \mathrm{gpd}$.

With the exception of occasional storm runoff, the entire flow of Turpentine Run becomes recharge to the alluvium. In a year of average rainfall, this is about 20 million gallons. Ground-water discharge from the upper basin to the alluvium is probably 25 million gallons or more annually, but about 15 million gallons is lost to eva potranspiration.

Storage. --From October 1965 to January 1966 there were four major and several minor rainstorms over the upper Turpentine Run basin. These storms contributed about 190 million gallons of water to the aquifer. Ground-water levels rose about 10 feet throughout the basin. Calculated storage capacity of this part of the aquifer is about 4 percent by volume. A rough estimate would place about 500 million gallons of water in storage when the aquifer is full; that is, when it starts to contribute to the base flow in the three branches of Turpentine Run.

The bedrock aquifer in the lower basin is estimated to be capable of storing 100 million gallons. The low storage capacity of the lower basin is attributed to fewer open foints and fractures in the rocks of the Water Island Formation. 
The principal alluvial deposits lying along Turpentine Run in the lower basin when saturated to the base level of the stream, have a storage capacity estimated to be 5 million gallons of water above sea level.

Yield.--Annual recharge to the aquifer of the upper basin is about 105 million gallons, with a bonus of 55 million gallons or more about every other year--a working average of about 130 million gallons annually. Of this amount, about 10 million gallons is lost to base flow in Turpentine Run and 25 million gallons by subsurface ground-water discharge to the lower basin. The remainder, about 95 million gallons, is lost to evapotranspiration. Development of the aquifer would recover much of the water lost by evapotranspiration and also that lost by base flow and subsurface ground-water discharge. The estimated potential ground-water yield of the upper basin is 110 million gallons annually, or $300,000 \mathrm{gpd}$.

Recharge to the bedrock aquifer in the lower basin is assumed to be about 30 million gallons annually--less than that in the upper basin because of the general overall lower permeability as well as the dense vegetation and consequent greater soil-moisture demand. The alluvial aquifer, in turn, receives about 25 million gallons from ground-water flow and about 20 million gallons of surface-water flow from the upper basin. The dense brush and generally shallow water table cause large evapotranspiration losses. Probably three-fourths of the available ground water in the lower basin is lost to evapotranspiration. The remainder discharges to the sea. The potential yield of the lower basin is about 18 million gallons annually (50,000 gpd), equally divided between the bedrock and the alluvial aquifer.

Water use.--Before 1964 the use of ground water in the area was limited; the major water user was the Government abattoir at Nadir. Test drilling in 1964 proved drilled wells to be feasible, and with the advent of drilled wells, water use increased rapidly. Water, pumped by water haulers for sale to domestic users, and industrial use in the area is increasing. Estimates of ground-water pumpage and use are given in table 7 .

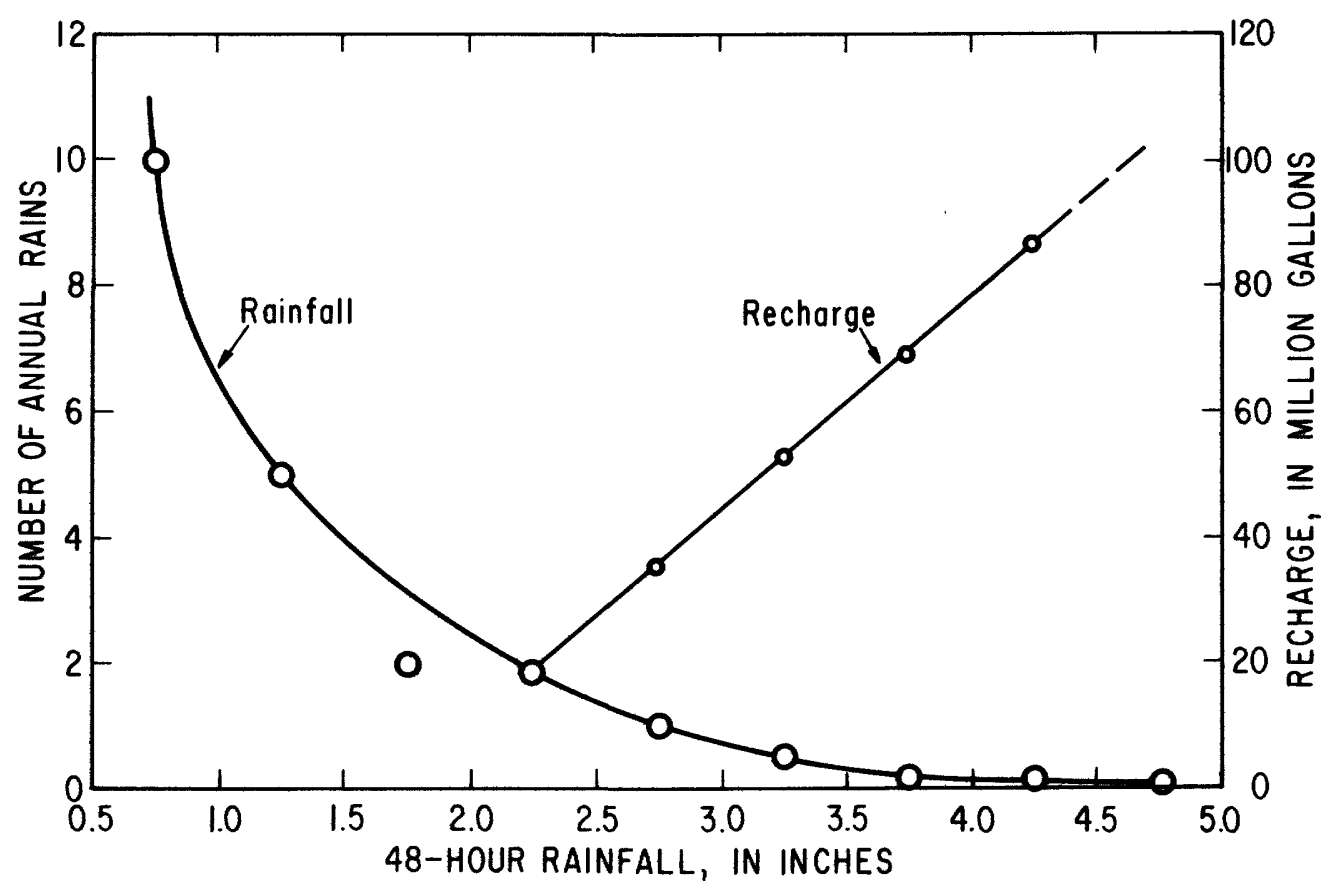

Figure 33.--Frequency of 48-hour rainstorm at Estate Fort Mylner ( $M t$. Zion) and recharge to aquifer of upper Turpentine Run basin. 
Table $7 .--$ Ground-water pumpage and use in Area 2, in million gallons

\begin{tabular}{c|c|c|c|c}
\hline Year & $\begin{array}{c}\text { Water } \\
\text { hauling }\end{array}$ & $\begin{array}{c}\text { Industrial } \\
\text { supply }\end{array}$ & $\begin{array}{r}\text { Public } \\
\text { supply }\end{array}$ & $\begin{array}{c}\text { Domestic } \\
\text { supply }\end{array}$ \\
\hline 1963 & 0 & 1.2 & 0.5 & 0.3 \\
1964 & 2.0 & 1.2 & .3 & .3 \\
1965 & 4.0 & 2.0 & .1 & .3 \\
1966 & 6.9 & 5.2 & .5 & .4 \\
1967 & 7.0 & 7.5 & .8 & .5 \\
\hline
\end{tabular}

Area 3

The north slope of St. Thomas, an area of approximately 4.6 square miles between Santa Marla Bay and Magens Bay, is included in Area 3. The bedrock is volcanic tuff and breccia and a few minor lava flows of the Louisenhoj Formation. A soil and saprolite zone up to 20 feet thick covers the bedrock, and deep weathering occurs along fractures. Weathering along fractures was observed to a depth to 140 feet in well 3, and it probably extends to greater depths. Several prominent embayments are filled with alluvium and beach deposits.

Bedrock.--Ground water occurs in the fractures in the becirock and locally in the soil and saprolite. The soil and saprolite zone have a relatively high infiltration rate along cracks and crevices when relatively dry but a fairly low overall permeability when saturated. This zone, when saturated, contributes water to the underlying bedrock. It is a major source of water feeding the several springs in the area and Bonne Resolution Gut. Recharge from small rains does not reach the saturated zone in the bedrock but does increase the amount of temporary storage in the soil and saprolite zone. This is evident when small rains that cause no rise in the water level in the bedrock cause a marked increase in spring discharge and base flow of the stream.

Ground-water levels are shallow ( 40 to 50 feet) even at altitudes of 600 to 700 feet. Well depths range from about 80 to 200 feet, depending on the yield desired and depth of water-bearing fractures. Shallow wells will probably yield 1,000 to 2,000 gpd, whereas deeper wells may yield as much as $10,000 \mathrm{gpd}$.

Potential ground-water yield from the area is estimated to be $250,000 \mathrm{gpd}$.

Salt water is probably present in the waterbearing rocks on peninsulas and along the immediate coastline. Wells drilled close to the sea and bottomed below sea level could be affected by salt-water encroachment. The overall high altitude of the land surface and water table above the sea will generally enable the completion of wells with the bottom altitude above sea level, thus eliminating the danger of seawater encroachment.

Alluvial and beach deposits.--Alluvium and beach sand-filled embayments at Santa Marla, Neltjeberg, Dorothea, and Hull Bays contain fresh water. The fresh water in the embayment deposits is replenished periodically by storm runoff. The water absorbed by the deposits is retained mostly in the alluvium, which is less permeable than the beach sand. Recharge to the beach sand discharges rapidly to the sea, whereas that in the less permeable alluvium is retained and discharges more slowly through the sand to the sea.

The small volume of water retained in longterm storage limits the potential yield of the embayment deposits. Estimated potential yields range from $500 \mathrm{gpd}$ at Santa Marla Bay to 5,000 gpd at Dorothea Bay. The relative high yield at Dorothea is the result of the flow of Bonne Resolution Gut replenishing the water-bearing deposits.

Area 4

Area 4, in north central St. Thomas, is underlain by the Outer Brass Limestone in a narrow strip extending from Magens Bay eastward to Estate Mandal.

Bedrock.--The highly fractured limestone dips to the north at about 50 degrees; its outcrop area, paralleling the valley floor, is 500 to 600 feet wide. The limestone is bound on the south by the Louisenhoj Formation and on the north by the Tutu Formation. The eastern part of the area is a prominent westward-trending valley eroded into the limestone. A volcanic rock watershed of about half a square mile contributes storm runoff to the valley. The valley terminates abruptly at its west end and trends northward through a gap in the surrounding hills to Lovenlund Bay. West of where the valley trends sharply northward, the 
land surface rises to a divide and then descends to Magens Bay. This divide separates the eastern and western parts of the limestone and is probably also a ground-water divide. East of the divide, ground-water flow is westward down the valley and then northward (probably following a fault zone) through the gap in the hills to Lovenlund Bay. West of the divide, ground water probably discharges to Magens Bay.

Eastern valley.--The limestone of the valley is an excellent aquifer, although of small areal extent. Well 16, drilled to a depth of 80 feet near the center of the valley is capable of short-term yields of $150,000 \mathrm{gpd}$ and sustained yields estimated to be $50,000 \mathrm{gpd}$. About $100,000 \mathrm{gpd}$ is being discharged to sea from the limestone.

The aquifer in the valley is recharged principally by direct infiltration of rain and by the infiltration along the stream channel of storm runoff from the volcanic rock watershed of about half a square mile. On the basis of estimated discharge from the aquifer, annual recharge is the equivalent of about 5 inches of rainfall on the area of the limestone.

The yield of the aquifer is that of the estimated annual recharge, about $100,000 \mathrm{gpd}$. Some mining of water would be possible during years of less than average recharge--the water being replaced in years of above-average recharge.

The yield of the aquifer likely could be increased by about $40,000 \mathrm{gpd}$ through the utilization of the storm runoff that normally escapes to the sea by building a series of small retention reservoirs in the stream channel. Reservoirs in the limestone part of the channel would leak and the aquifer would be recharged through this leakage. Reservoirs in the upper part of the basin underlain by volcanic rock would not leak. Water stored in these reservoirs could be released to the leaky reservoirs downstream for recharge as storage became available in the aquifer.

Western slope.--The ground-water potential west of the topographic divide is probably slight, limited essentially to recharge from rainfall on the outcrop, if, as assumed, ground water is discharged from the remainder of the limestone northward to the sea. Water in the limestone near Magens Bay is brackish, although it is assumed that fresh water is present farther inland. Wells tapping fresh water in the aquifer could be developed near the topographic divide. Excessive pumpage and lowering of water levels, of course, could result in salt-water encroachment from Magens Bay and possibly Lovenlund Bay. If the aquifer in the eastern valley were fully developed, water pumped from the western part of the limestone would diminish and eventually eliminate the fresh-water barrier between the main producing zone and potential salt-water encroachment from Magens Bay.

\section{Area 5}

The greater part of Area 5 is a U-shaped segment paralleling the coast of eastern St. Thomas. It is underlain in the north by the Tutu, the Louisenhoj, and the Outer Brass Formations and on the south by the Water Island Formation. Small parts of Area 5 along the south coast and in the west end of the island are underlain by the Water Island Formation and the Louisenhoj Formation or by intrusive rocks. Throughout the coastal part of the area are embayments filled with alluvium and beach deposits. The area, as a whole, lies within a zone where rainfall is less than 40 inches annually.

North and east from Magens Bay to Brenner Bay, Area 5 is marked by high ridges and steep slopes. The steep slopes and very thin soil cover form a combination that is not conducive to recharge. Water that does enter the rocks drains rapidly to low-lying areas or to the sea. Wells will yield little or no water on the steep ridges or their seaward slopes. Yields up to $500 \mathrm{gpd}$ can be obtained from wells on the lower slopes of the inland side of the ridges and on the larger peninsulas. The water in general is brackish, although some fresh water may be available near the contact with Areas 1 and 4.

At the west end of St. Thomas it may be possible to obtain yields of $200 \mathrm{gpd}$ from wells. Because of the topography, low rainfall. and lack of recharge, the area would not likely support an extensive ground-water development.

Between Mt. Pleasant and Red Hook Hill on the north coast the land is low lying, with salt ponds and marshes scattered along the seaward margin. Wells tapping the rocks of this area yield 1,000 gpd or more, but usually brackish water is obtained. Low rainfall and, 
consequently, little recharge in conjunction with the salt ponds and marshes are contributing factors to the brackish ground water in this area.

On the south coast between Mangrove Lagoon and Charlotte Amalie the rocks are well fractured, but many of the fractures are filled with secondary minerals. Well 25 at Mangrove Lagoon, drilled to a depth of 100 feet, penetrated no water-bearing fractures. Drill cuttings showed zones containing large amounts of secondary calcite as fracture fill.

Yields of wells on the south coast will generally be less than $500 \mathrm{gpd}$. The greatest yields are likely in the larger valleys. Ground water is fresh except along the coast and on the peninsulas, where water of varying degrees of brackishness is present.

As much as 1,000 gpd can be obtained from dug wells and 10,000 gpd from drilled wells in the vicinity of Charlotte Amalie. The ground water, with few exceptions, is contaminated by leakage from salt-water mains or by salt-water encroachment and polluted by leakage from sewage mains.

\section{WATER QUALITY}

The quality of surface water and ground water is greatly influenced by the sea. Salt water not only adjoins the island but also underlies it in the aquifers along the coast. Through out the island, salt-laden dust, derived from salt spray from the ocean falls on the land surface or is washed from the atmosphere by rain. Along the coast, salty ocean spray is blow inland from heavy surf. Spray has been observed as a fine mist at altitudes as high as 300 feet.

In addition to the sea-derived minerals, mineralladen dust from the land is picked up by the wind to be delivered later as dry fallout or washed from the atmosphere by rain.

Bulk fallout, the combination of dry fallout and minerals washed from the atmosphere by rain, is concentrated on the land surface or is absorbed and carried into the upper part of the soil zone by minor rains, where it is redeposited as the moisture is removed by evapotranspiration. Other soluble minerals are present in the soil that have been derived from weathering of the parent rock or deposition of animal and human wastes. Plants also add minerals to the soil. They utilize gasses, principally carbon dioxide and nitrogen, from the atmosphere in the photosynthesis process. Some release bicarbonate from their root systems; others, the legumes, have nitrogen-ixing nodules on their roots. (False tamarind, a small tree covering large areas, is the principal legume of St. Thomas.) These minerals remain in the soil zone until dissolved by heavy rain. They are then carried to the ground-water reservoir or are incorporated in the runoff.

The rapidity with which minerals in the soil go into solution is best shown in analysis 6 (table $\varepsilon$ ) from Turpentine Run, when its flow was nearly 100 percent storm runoff, after a 5 -inch rain over the watershed in the preceding 24 hours. The mineral constituents of the water were nearly 15 times greater than found in rainfall. It is concluded that these constituents were leached from the soil during overland flow in the previous 24 hours.

Water in the ground-water reservoir will continue to dissolve minerals from the rocks through which it moves until it becomes saturated. In contrast, streamflow, which 90 percent of the time is ground-water discharge, sometimes precipitates minerals. In general, streamflow shows little difference in mineral content except for dilution by storm runoff.

Possible sources for the chemical constituents of the waters are given below:

\begin{tabular}{l|l|l}
\hline \multicolumn{1}{|c|}{ Sea $1 /$} & \multicolumn{1}{|c|}{ Land $2 /$} & Atmosphere $3 /$ \\
\hline Sodium & Sodium & \\
Sulfate & Sulfate & \\
Chloride & Bicarbonate & Bicarbonate \\
Magnesium & Calcium & Nitrate \\
Potassium & Silica & \\
& Nitrate 4/ &
\end{tabular}

The result is a water of a mixed chemical classification, displaying characteristics of sea and land-derived minerals (fig. 34).

1 Sea minerals contributed to the waters by dry fallout, spray, or encroachment--derived directly from the sea. 
Table 8 --Analyses of water of St. Thomas

\begin{tabular}{|c|c|c|c|c|c|c|c|c|c|c|c|c|c|c|c|}
\hline Locations -- - - & 1 & 2 & 3 & 4 & 5 & 6 & 7 & 8 & 9 & 10 & 11 & 12 & 13 & 14 & 15 \\
\hline $\begin{array}{l}\text { Date- }------- \\
\text { Year }-------\end{array}$ & $\begin{array}{l}9-29 \\
1964 \\
\end{array}$ & $\mid \begin{array}{c}11-19 \\
1963\end{array}$ & $\begin{array}{c}10-14 \\
1963\end{array}$ & $\begin{array}{c}1-2 \\
1964\end{array}$ & $\begin{array}{c}12-22 \\
1964\end{array}$ & $\begin{array}{l}8-29 \\
1963\end{array}$ & \begin{tabular}{|c|}
$11-24$ \\
1963
\end{tabular} & $\begin{array}{l}7-22 \\
1964\end{array}$ & $\begin{array}{r}11-16 \\
1963\end{array}$ & $\begin{array}{l}8-22 \\
1964\end{array}$ & $\begin{array}{r}12-17 \\
1963\end{array}$ & $\begin{array}{l}1-24 \\
1964\end{array}$ & & & $\begin{array}{l}5-20 \\
1964\end{array}$ \\
\hline \multicolumn{16}{|c|}{ Milligrams per liter } \\
\hline Silica $\left(\mathrm{SiO}_{2}\right)$ & 33 & 23 & 28 & 36 & 32 & 20 & 27 & -- & 26 & 25 & 29 & 26 & 20 & 33 & 20 \\
\hline Iron ( $\mathrm{Fe}$ ) & 0.00 & 0.00 & 0.04 & 0.00 & 0.00 & 0.13 & 0.04 & 0.00 & 0.00 & 0.00 & 0.00 & 0.00 & 0.00 & 0.09 & 0.32 \\
\hline Calcium ( Ca) & 14 & 48 & 59 & 48 & 38 & 20 & 46 & 30 & 34 & 40 & 52 & 74 & 48 & 94 & 4 \\
\hline Magnesium ( $\mathrm{Mg}$ ) & 15 & 45 & 57 & 46 & 34 & 11 & 61 & 77 & 36 & 39 & 43 & 108 & 39 & 68 & 4.9 \\
\hline $\begin{array}{l}\text { Sodium-Potassium } \\
\text { ( } \mathrm{Na} \text { and } \mathrm{K} \text { ) }\end{array}$ & 245 & 464 & 372 & 293 & 295 & 81 & 477 & 519 & 363 & 353 & 488 & 718 & 355 & 359 & 25 \\
\hline Bicarbonate $\left(\mathrm{HCO}_{3}\right)$ & 524 & 726 & 730 & 758 & 668 & 188 & 1,010 & 1,028 & 772 & 704 & 935 & 848 & 798 & 772 & 36 \\
\hline Sulfate $\left(\mathrm{SO}_{4}\right)$ & 37 & 90 & 131 & 32 & 35 & 17 & 60 & 50 & 51 & 56 & 27 & 120 & 37 & 142 & 4 \\
\hline Chloride (C1) & 112 & 432 & 305 & 200 & 200 & 70 & 360 & 440 & 235 & 275 & 405 & 962 & 255 & 362 & 36 \\
\hline Fluoride (F) & .4 & 1.2 & .9 & 1.0 & .8 & .3 & 1.0 & 1.3 & .5 & .8 & .8 & .5 & .4 & 1.0 & .1 \\
\hline Nitrate $\left(\mathrm{NO}_{3}\right)$ & 3 & 17 & 28 & 9.4 & 10 & .6 & 3.9 & 1.8 & 3.8 & 2.3 & 0 & 15 & .0 & 0.3 & .2 \\
\hline Dissolved solids & 727 & 1,440 & 1,300 & 963 & 994 & -- & 1,480 & 1,700 & 1,110 & 1,150 & 1,510 & 2,380 & 1,080 & 1,470 & 160 \\
\hline Hardness $\left(\mathrm{CaCO}_{3}\right)$ & 96 & 305 & 382 & 309 & 235 & 95 & 366 & 392 & 233 & 260 & 306 & 628 & 280 & 514 & 30 \\
\hline $\begin{array}{l}\text { Specific conduct- } \\
\text { ance (micromhos } \\
\text { at } 25^{\circ} \mathrm{C} \text { ) }\end{array}$ & 1,210 & 2,490 & 2,200 & 1,670 & 1,680 & 541 & 2,500 & 2,780 & 1,820 & 1,910 & 2,500 & 4,240 & 1,870 & 2,400 & 193 \\
\hline $\mathrm{pH}$ & 8.1 & 8.0 & 7.9 & 7.9 & 7.7 & 7.4 & 7.4 & 8.1 & 8.1 & 7.9 & 8.3 & 7.8 & 7.8 & 7.7 & 6.8 \\
\hline
\end{tabular}

* Locations of sites listed above are given below:

1. Well 3 in volcanic rock of Louisenhoj Formation.

2. Well 10

3. Well 18 do

4. Well 19

do

do

5. Well 12 do

6. Turpentine Run near Mt. Zion storm runoff discharge $1,700 \mathrm{gpm}$.

7. Turpentine Run near Mt. Zion, base-flow discharge $9 \mathrm{gpm}$.

8. Turpentine Run near Mt. Zion, base-flow discharge $1 \mathrm{gpm}$.
9. Bonne Resolution Gut at Bonne Resolution, base-flow discharge $15 \mathrm{gpm}$.

10. Same as above-base-flow discharge $5 \mathrm{gpm}$.

11. Well 23 in shallow alluvium, Lower Turpentine Run Valley.

12. Well 24 in deep alluvium and bedrock, Lower Turpentine Run Valley.

13. Well 2 in shallow alluvium of coastal embayment.

14. Well 16 in Outer Brass Limestone.

15. Hoffman Pond, Upper Turpentine Run basin. 


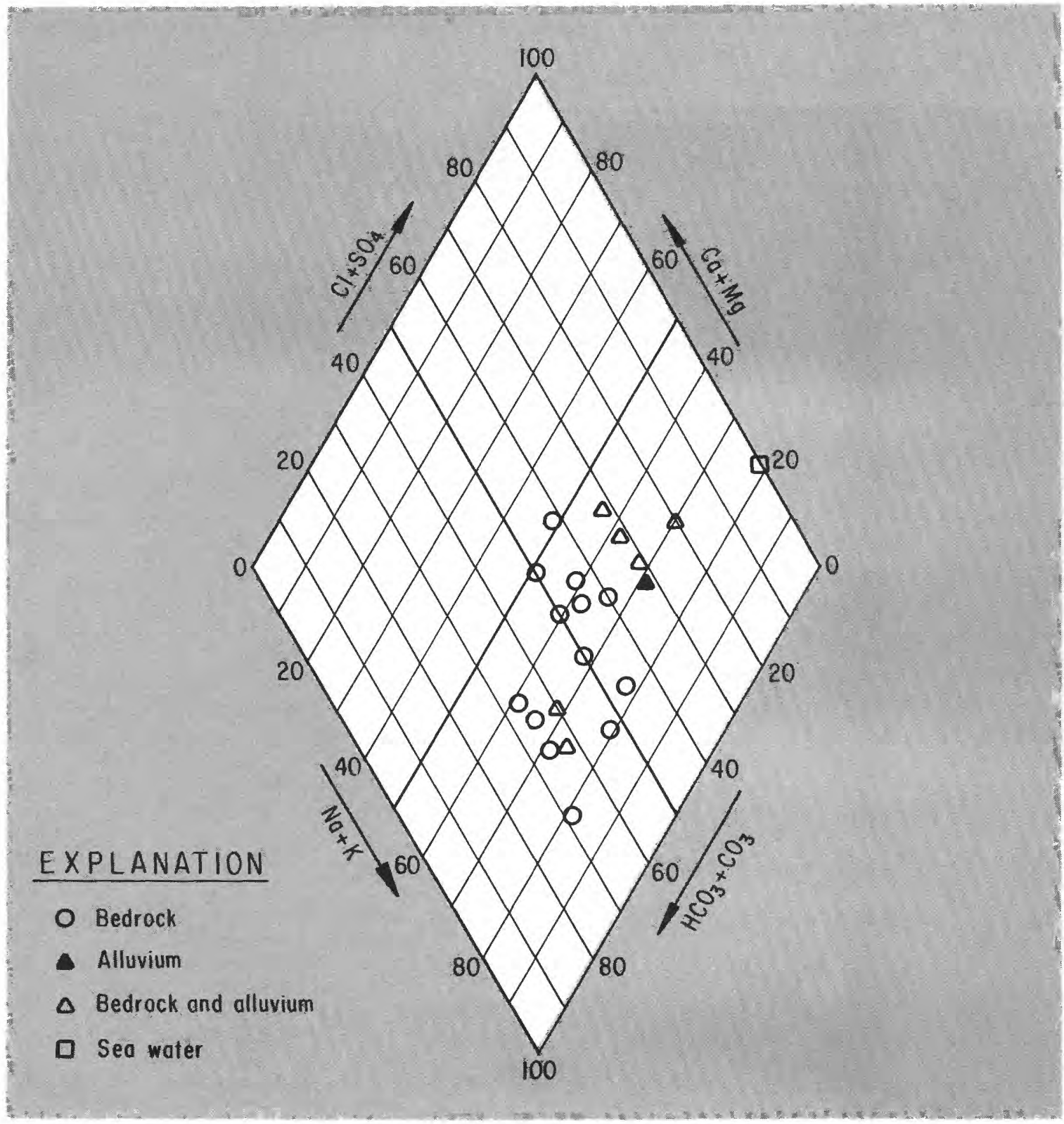

Figure 34.--Chemical classification of ground water of St. Thomas in percent of total equivalent per liter.

2/ Land minerals contributed to water by fallout as land-derived dust or dissolved from the minerals of the soil zone or bedrock.

3/ Atmosphere minerals taken from the atmosphere as gasses in the photosynthesis process by plants and deposited by the root system in the soil.

4/ Animal and human wastes and legumes.

\section{Bulk Fallout}

Airborne bulk fallout, including windborne sea spray, contributes all to one-fifth of the chemical components of surface water and ground water. About half the bulk fallout is derived from the sea, the rest from the land. Most of the bulk fallout from land sources originates on the island; but part of it is windborne from other areas.

Table 9.--Comparison of bulk fallout and dilute sea water

\begin{tabular}{|c|c|c|c|c|c|c|c|c|c|c|c|c|c|c|}
\hline \multirow[b]{3}{*}{ Bulk fallout } & \multicolumn{2}{|r|}{$\mathrm{Ca}$} & \multicolumn{2}{|r|}{$\mathrm{Mg}$} & \multicolumn{2}{|c|}{$\mathrm{Na}, \mathrm{K}$} & \multicolumn{2}{|c|}{$\mathrm{HCO}_{3}$} & \multicolumn{2}{|c|}{$\mathrm{SO}_{4}$} & \multicolumn{2}{|r|}{$\mathrm{Cl}$} & \multirow{2}{*}{$\begin{array}{c}\begin{array}{c}\text { Dissolved } \\
\text { solids }\end{array} \\
\mathrm{mg} / 1 \\
\end{array}$} & \multirow{2}{*}{\begin{tabular}{|c|} 
Total \\
epl \\
\end{tabular}} \\
\hline & $\mathrm{mg} / \mathrm{l}$ & epl & $\mathrm{mg} / \mathrm{l}$ & epl & $\mathrm{mg} / 1$ & epl & $\mathrm{mg} / \mathrm{l}$ & epl & $\mathrm{mg} / \mathrm{l}$ & epl & $\mathrm{mg} / \mathrm{l}$ & epl & & \\
\hline & 1.8 & 0.0900 & 0.3 & 0.0125 & 4.2 & 0.1830 & 6.7 & 0.1100 & 2.1 & $|0.0433|$ & 4.5 & 0.1270 & 20 & 0.5558 \\
\hline $\begin{array}{l}\text { Dilute sea } \\
\text { water }\end{array}$ & .1 & .0050 & .3 & .0025 & 2.5 & .1090 & .03 & .0005 & .6 & .0124 & 4.5 & .1270 & 8 & .2564 \\
\hline
\end{tabular}


Partial analyses of the mineral content of bulk fallout, the combination of dry fall out and minerals washed from the atmosphere by rain, were made of samples collected at Bonne Field near the airport. The chloride content, assumed to be almost wholly of ocean-salts origin, ranged from 1 to $13 \mathrm{mg} / 1$ (milligrams per liter) and averaged 4.5 $\mathrm{mg} / \mathrm{l}$. The chloride content varied, depending upon elapsed time since the last rain, the amount of rainfall, the wind, and the surf. A comparison of the average major constituents of bulk fallout and sea water diluted to a chloride content of 4.5 $\mathrm{mg} / \mathrm{l}$ is given in table 9 .
Surface Water

The mineral content of water in streams (analyses $6,7,8,9$, and 10 in table 8) increases as flow decreases, reflecting an increasing percentage of more highly mineralized ground water, which has had longer contact with the rock and also has been concentrated by evapotranspiration in moving from points of recharge to points of discharge. Figure 35 shows the chloride content of the waters of Turpentine Run and Bonne Resolution Gut in relation to discharge. The smaller chloride content of water in Bonne Resolution Gut, as compared with that of Turpentine Run, is attributed to more frequent recharge and a shorter time of travel between recharge and discharge of water in the surficial deposits, which are a major source of water to Bonne Resolution Gut.

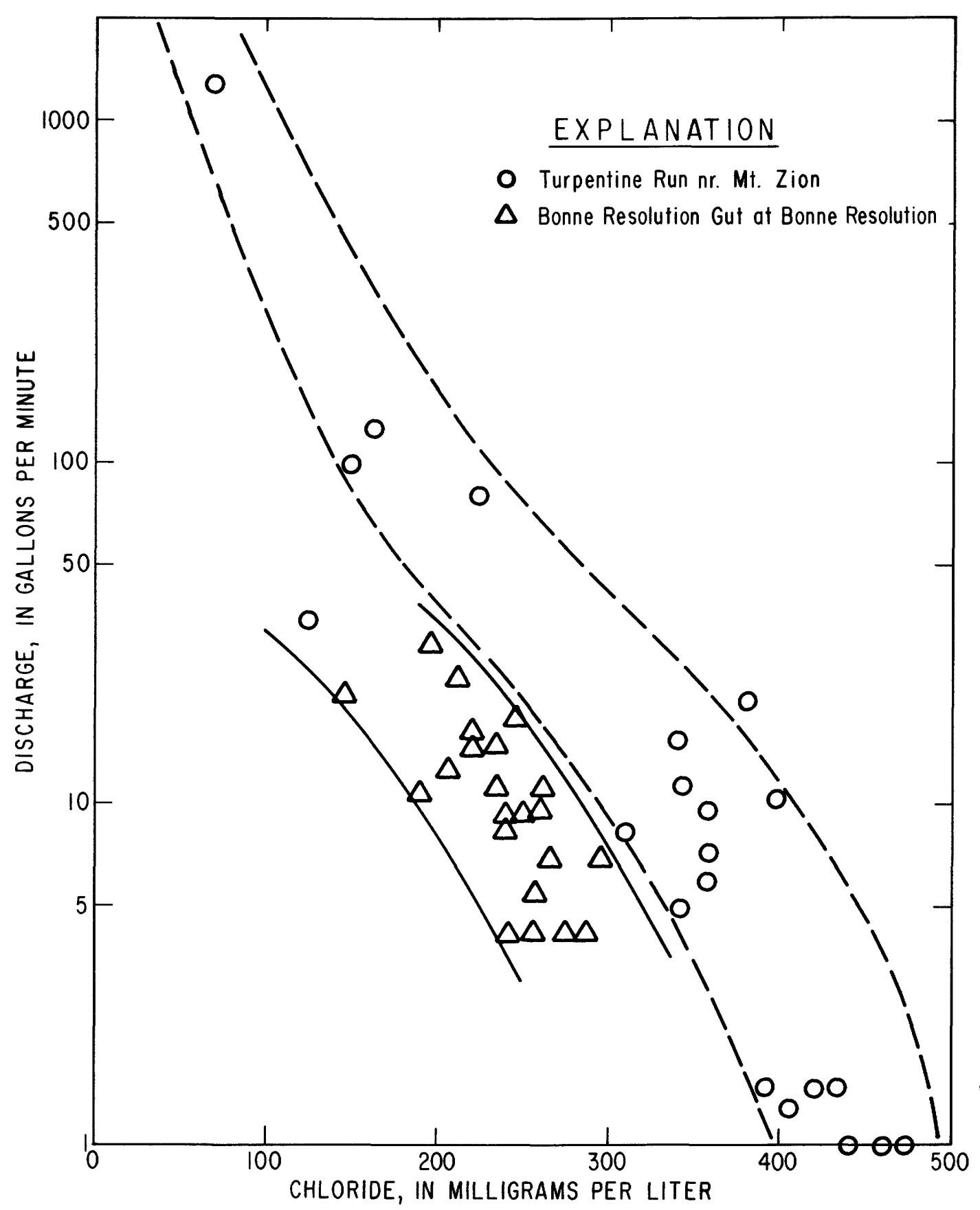

Figure 35.--Relation of chloride content of water to discharge of Turpentine Run and Bonne Resolution Gut. 


\section{Ponds}

Small farm ponds are replenished by storm runoff, and the quality of the water, in large part, depends on the contact time and volume of the runoff with the land surface before entering the pond. Water in Hoffman Pond, analysis 15, is representative of the pond water. The increase in the chloride content of the water in the pond in conjunction with decline in stage and volume (fig. 22 ) is attributed to concentration by evaporation.

\section{Sedimentation}

Field observations show that streams carry little sediment during low flow. Sediment observed during runoff from rains up to 5 inches was predominantly fine grained, seldom exceeding coarse-sand size. An exception was Bonne Resolution Gut, where gravel as large as 1 inch in diameter was carried downstream and deposited behind natural and artificial barriers.

Farm ponds are often on slopes of 20 degrees or more, with watersheds of 5 to 10 acres covered with grass or brush on a thin bouldery soil. These ponds, most of which are 4 to 5 years old, have but a few inches of fine-grained sediments in their upstream ends.

Water in ponds is generally clouded with clay and other fine-grained sediments, which have been observed to remain in suspension for as long as a year.

\section{Ground Water}

The general character of the water in the volcanic rocks is indicated by the analyses $1,2,3$, and 4 of samples from wells (table 8 ) and the classification diagram in figure 34. Dissolved-solids content of the water is 700 to $1,400 \mathrm{mg} / 1$, and chloride content is 100 to $400 \mathrm{mg} / 1$. As the chloride content is assumed to be derived almost wholly from ocean-derived salts from the atmosphere, a concentration of bulk fallout in the soil zone with subsequent movement into the aquifer during recharge is indicated. The variations in the chloride and overall mineral content of the water reflect the volume of recharge entering the aquifer. The greater the volume of recharge, the more dilution of the soluble minerals in the bulk fallout. Further concentration of the mineral con- tent of the ground water occurs through water losses by evapotranspiration from the aquifer.

The dilution effect is indicated by a comparison of analysis 5 (table 8) from well 12 in the Long Bay area, where annual recharge is estimated to be 5 inches, and analysis 2 of nearby well 10 in similar rock, where annual recharge is estimated to be one inch.

\section{Salt-Water Interface}

In the coastal areas the fresh-salt-water interface fluctuates with the volume of fresh water discharging to the sea. On peninsulas and in the drier ea stern part, the salt-water interface extends well inland because of the lack of recharge. The quality of water in these areas varies with the position of the interface. Well 2, analysis 13 , taps an alluvial aquifer in a coastal embayment. The chloride content of the water from this well has ranged from 115 to $640 \mathrm{mg} / \mathrm{l}$, as the interface fluctuated seaward and landward in the aquifer.

\section{Pollution}

The water resources of the island can be rendered unfit for human consumption, irrigation, or industrial use through contamination by salt water or pollution by sewage wastes.

Salt water can readily enter the fresh-water aquifers along the coast if wells are improperly constructed or if fresh water in underground storage is depleted by overpumping. There is a general tendency to drill a well deeper than is safe in order to obtain a greater yield. In the coastal areas, the deeper the well, the greater the possibility of penetrating the base of the freshwater lens and obtaining brackish water.

Controlled pumping is the key to preventing salt-water encroachment. Local reduction of the fresh-water head by pumping will cause salt water to rise in the aquifer beneath the well. The larger the pumping rate, the greater the reduction of the fresh-water head and the subsequent rise of salt water. Excessive drawdown eventually leads to the encroachment of salt water into the fresh-water aquifers.

A great danger to the natural waters is pollution 
by sewage. The rapid increase in population has resulted in a corresponding increase in housing and housing developments in the headwaters of the streams and in areas of ground-water recharge. Individual rural houses depend on septic tanks or outside privies for the disposal of sewage. Because of the thin soil cover, effluent is not properly filtered. In many places the effluent, after passing a short distance through the soil, is discharged at the land surface or enters open fractures in the bedrock. Although effluent discharge to the land surface is an obvious hazard, that which enters the bedrock is not as readily apparent. Filtration is minimal in the fractures in the bedrock, and, as a result, bacteria-laden water can enter the aquifer. Even in the few areas where soil and surface conditions are effective in filtration of sewage wastes, too great a density of septic systems will result in overloading the filtration capacity of the subsoil, and pollution will result.

Many of the larger housing developments being built or in planning have sewage systems and small sewage-treatment plants connected with a pond for polishing effluent. This is an improvement over the individual septic-tank system, but it also can result in pollution of natural water supplies. The sewage plants when operating properly are about 90 percent efficient in bacterial removal. Polishing ponds, which are designed to retain the effluent for 1 day, are supposed to eliminate the remaining bacteria. After polishing, the effluent unless specially treated, will contain live virus and bacteria protected by tests (hard shell-like covers). An ever-present hazard is a breakdown or overloading of sewage-disposal plants as effluents are generally discharged into dry water courses. Plant breakdown under these conditions could be extremely hazardous. As the number of sewage-disposal plants increases and if effluent is discharged as at present, many stream channels will become open sewers. As areas of ground-water recharge and also areas for the potential development of surface-water and ground-water supplies lie along the stream channels, sewage pollution is a major hazard to these water supplies.

\section{ACKNOW LEDGMENTS}

In any project, there are numerous people in official and unofficial capacities who help make the project possible through technical assistance or by being helpful. We wish to thank the Virgin Islands Public Works Department, the Department of Agriculture, and the Planning Board, whose personnel helped us in many ways. There are also the many individuals who provided assistance by allowing us to establish stream-gaging stations, rainfall collectors, recording rain gages and observation wells and to drill test wells on their property. We also wish to thank the group who faithfully observed daily rainfall during the project: Messrs.R.R. Blackwell, H. Bonsole, W. Christiansen, J.A. Christmas, N. Davis, C. Fuentes, B.R. Neaman, K. Tyson, and W.L. Yaude. 
Bellante, E. L., and Garfield, J.R., 1961, Airport site studies, St. Thomas, Virgin Islands: Consultants' rept., $170 \mathrm{p}$.

Bowden, M.J., 1968, Water balance of a dry island: Geog. Pub. at Dartmouth, No. 6, 89 p., 26 figs.

Donnelly, T.W., 1960, The geology of St. Thomas and St. John, Virgin Islands : Caribbean Geol. Conf., 2d, Mayaguies, P.R., Jan. 4-9, 1959, Trans., p. 153-155.

1966, Geology of St. Thomas and St. John, U.S. Virgin Islands: Geol. Soc. of America Mem. 98, p. 85-176.

Gatewood, J.S., Robinson, T.W., Colby, B.R., Hem, J. D. , and Halpenny, L. C., 1950, Use of water by bottom-land vegetation in lower Stafford Valley, Arizona: U.S. Geol. Survey Water-Supply Paper 1103, 210 p., 45 figs., 5 pls.

Grossman, I.G., 1959, Ground water from St. Thomas, Virgin Islands: U.S. Geol。Survey open-file rept., 35 p., 1 fig.

1962, Chemical quality of ground water in St. Thomas, Virgin Islands: U.S. Geol. Survey Prof. Paper 450-B, p. B131-B133.

Johnson, A. F., 1936, Water supply for St. Thomas, Virgin Islands: U.S. Bur. Reclamation, mimeo. rept., 92 p., 1 pl.

Pettigrew, R. L., 1921, Water supply for Naval Base on St. Thomas: Rept. of Public Works Officer to Commandant, Bur. Yards and Docks, U.S. Navy, p.4.

Smedley, David, 1960, Special weather summary-Climatological data, Puerto Rico and Virgin Islands: May 1960, v. 6, no. 5, U.S. Dept. Commerce, Weather Bur., p. 50-53.

Tippetts-Abbott-McCarthy-Stratton, 1959, Potable water supply for St. Thomas, Virgin Islands: Consultants' rept, $50 \mathrm{p}$.

Vaughan, T.W., and Kidwell, C.H., 1920, The ground-water resources of the West Indian Islands, St. John, St. Thomas, Culebra, Vieques, and of the eastern end of Puerto Rico: U.S. Geol. Survey open-file rept., 53 p., 7 pls. 
Ward, P. E., and Jordan, D. G., 1963, Water resources of the Virgin Islands : a preliminary appraisal, U.S. Geol. Survey, open-file rept., 44 p., 7 figs.

Warfield, R. M., 1924, Report on water supply, Virgin Islands : U.S. Navy, p. 20.

Weather Bureau, 1961, Generalized estimates of probable maximum precipitation and rainfall frequency data for Puerto Rico and Virgin Islands : U.S. Dept. Commerce, Weather Bur. Tech. Paper No. 42, 94 p.

1958-65, Monthly summaries of rainfall : U.S. Dept. Commerce. 